\title{
Stable isotope geochemistry of Paleocene to Early Eocene strata around southern New Zealand
}

By

Dylan James Meadows

\author{
Thesis submitted to Victoria University of Wellington \\ in fulfilment of the requirements for the degree of \\ Master of Science (Geology)
}

School of Geography, Environment, and Earth Sciences Victoria University of Wellington September 2009 


\begin{abstract}
The Late Teurian (Paleocene) Tartan Formation is an organic-rich mudstone that has been identified in five of the eight exploration wells drilled in the Great South Basin, and three of four exploration wells drilled in the Canterbury Basin.

In this study, the geochemistry of two wells from the Great South Basin (Pukaki-1 and Rakiura-1) and four wells from the Canterbury Basin in southern New Zealand (Resolution1, Clipper-1, Galleon-1, and Endeavour-1) have been investigated using elemental analyser isotope ratio mass spectrometric (EA-IRMS) analyses on selected sidewall core and cuttings samples. This study builds on previous geochemical work by the author from five other wells from the Great South Basin (Takapu-1A, Toroa-1, Pakaha-1, Kawau-1A, and Hoiho$1 \mathrm{C})$.

All wells except Rakiura-1, Takapu-1A, and Resolution-1 showed geochemical characteristics that allowed recognition of the Tartan Formation. The formation is characterised by enrichments in TOC (typically above $3 \%$ ) and ${ }^{13} \mathrm{C}$ (generally $\delta^{13} \mathrm{C}$ ratios are between -21 and $-17 \%$ ), indicating a significant marine contribution. $\mathrm{C} / \mathrm{N}$ ratios recorded within the Tartan Formation are all above 20, which suggest that the organic matter contains a significant contribution from terrestrial and/or altered marine material. Geochemical evidence of samples within the Tartan Formation suggests that it contains a mixture of marine bacterial/plant/algal and $\mathrm{C}_{3}$ terrestrial plant source components. This is consistent with the findings of Killops et al. (2000), who reported from biomarker studies that the organic matter of some Great South Basin samples contained organic matter derived from a marine source with varying degrees of terrestrial contribution.

The Tartan Formation is distinct from enclosing formations which are characterised by low organic contents (generally below $2 \%$ ), isotopically light $\delta^{13} \mathrm{C}$ values (typically around $-26 \%$ ), which is indicative of terrestrial $\mathrm{C}_{3}$ plant matter, and a wide range of $\mathrm{C} / \mathrm{N}$ ratios (ranging from 4 to 64). The latter suggests that there were varying degrees of preservation of the deposited organic matter within these formations. Organic matter within enclosing formations appears to be derived from a combination of $\mathrm{C}_{3}$ land plants and marine material.

The high TOC content of Tartan Formation sediments compared to the underlying formation suggests that it represents a profound change in depositional conditions. Conditions for the preservation and accumulation of organic matter were more favorable prior to deposition of the Tartan Formation than following it.

The enrichment of ${ }^{13} \mathrm{C}$ and the high TOC contents within the Tartan Formation are similar to those for the mid to Late Teurian Waipawa Formation that has been identified throughout many of New Zealand's major sedimentary basins; however, TOC and $\delta^{13} \mathrm{C}$ values for the Tartan Formation exceed those previously reported for the Waipawa Formation.

Geochemical changes characteristic of the Tartan Formation are recognised below the lithological base of the formation in some wells, contemporaneous with the onset of the Paleocene Carbon Isotope Maximum (PCIM), and represent different lithostratigraphic expressions of that event. Termination of the environmental effects associated with the PCIM around New Zealand appears to have been diachronous and differences between the exact ages and stratigraphic positions of the Tartan and Waipawa formations are attributed to local environmental variations during deposition. TOC and $\delta^{13} \mathrm{C}$ enrichments associated with the Tartan Formation are not ubiquitous, and the formation has variable thickness throughout the Great South and Canterbury basins. It is concluded that the Tartan and Waipawa formations are correlatives.
\end{abstract}




\section{ACKNOWLEDGEMENTS}

I would like to thank my supervisor, A/Prof John Collen for his time and valuable discussions that made this study possible and in maintaining its direction. In particular I would like to thank John for his constructive supervision, thorough editing and helping with the drafting of figures throughout this study.

I would like to extend special thanks to Dr. Karyne Rogers (GNS) whom assisted me during the preparation stages, ran all the mass spectrometry samples, and was in frequent contact with to discuss many aspects relating to the study, greatly expanding my scientific knowledge.

I would also like thank Dr. Poul Schioler of GNS Science for his contribution and communications during this project. GNS Science contributed greatly to this project in several other ways.

The following VUW staff also assisted me during this project:

Professor Joel Baker, who let me use his laboratory to prepare samples, and Ms. Gillian Ruthven for assistance with formatting and finalisation of this project.

I would like to extend thanks to the examiners of this work, Mike Hannah and Richard Cook, whose thoughtful reviews and comments improved this thesis.

And finally, no dissertation would be complete without the acknowledgement of my parents and friends, Colin and Natalie, my Great Uncle, Bob, and Melanie. All of you assisted me during this project and I cannot thank each of you enough. 


\section{TABLE OF CONTENTS}

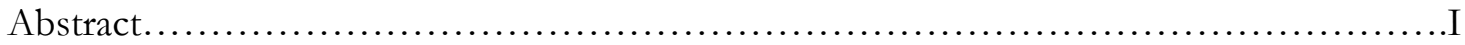

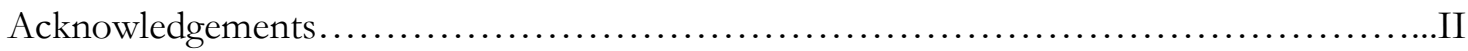

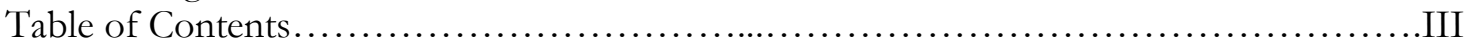

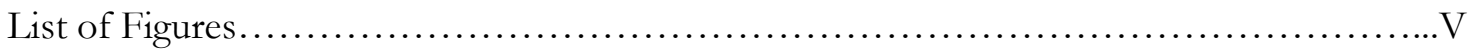

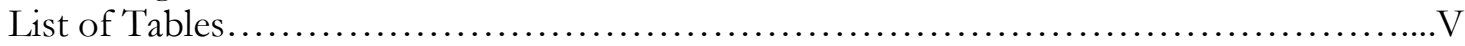

CHAPTER 1. Introduction......................................................

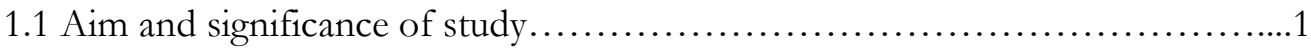

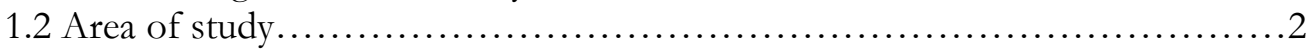

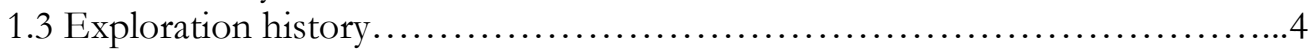

1.4 Previous studies of the Great South Basin............................... 5

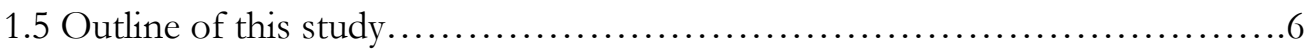

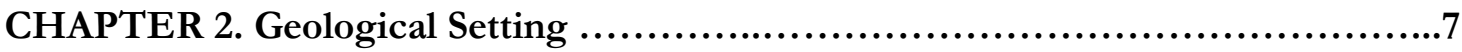

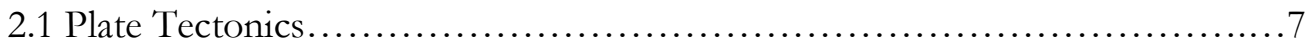

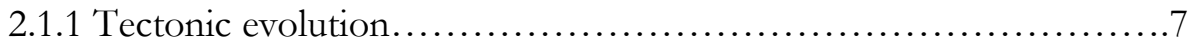

2.1.2 Structure of the Great South Basin..............................11

2.1.3 Structure of the Canterbury Basin.................................12

2.2 Stratigraphy of the Great South and Canterbury basins .....................13

2.2.1 The Great South Basin......................................13

2.2.2 Stratigraphy and Structure of GSB Exploration wells.................18

2.2.3 The Canterbury Basin.......................................20

2.2.4 Stratigraphy and Structure of CB Exploration Wells...............26

2.3 The East Coast Basin.................................................27

2.3.1 Stratigraphy of the East Coast Basin............................27

CHAPTER 3. The Tartan Formation............................................

3.1 Nomenclature and distribution of the Tartan Formation (and equivalents)......31

3.2 Thickness and depositional environment of the WF and TF.................33

3.3 Lithology and recognition of the Tartan Formation...........................38

3.4 Tartan geochemical facies..................................................

3.5 Age of the Tartan Formation (and equivalents)...........................39

CHAPTER 4. Environmental conditions across the Paleocene to Eocene...............41

4.1 Early Paleogene temperature fluctuations................................41

4.2 Paleoceanographic conditions from the Paleocene to Eocene ....................43

4.3 Isotopic and biological variations during the Paleocene to Eocene ....................45

CHAPTER 5. Method and Analytical Procedures...............................50

Dylan Meadows, $2009 . \quad$ V 


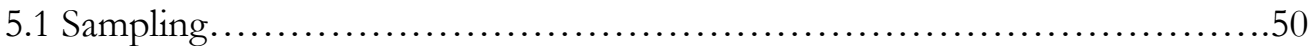

5.2 Sample preparation................................................. 50

5.3 Mass Spectrometry................................................. 51

CHAPTER 6. Results.........................................................5

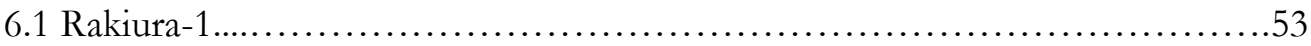

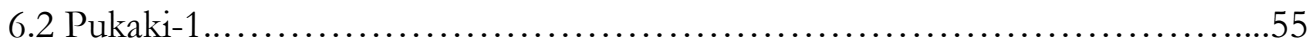

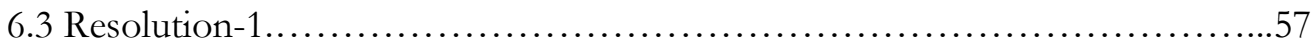

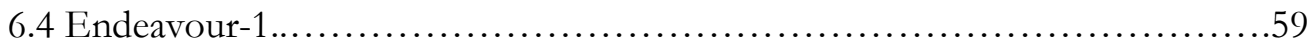

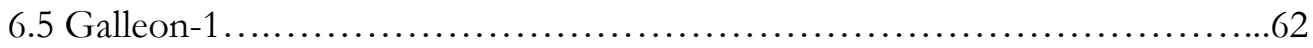

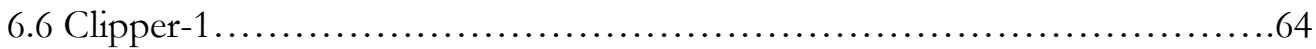

6.7 TOC correlation between wells across the GSB and CB...........................66

6.8 Correlation of Nitrogen \% between wells across the GSB and CB................70

$6.9 \mathrm{C} / \mathrm{N}$ correlation between wells across the GSB and CB.........................71

$6.10 \delta^{13} \mathrm{C}$ correlation between wells across the GSB and CB.........................76

CHAPTER 7. Discussion...................................................... 82

7.1 Geochemical correlation to Gamma Ray logs...........................82

7.2 Source of Organic Matter in samples from the GSB and CB.....................84

7.3 Correlation of latest geochemical data to Meadows (2008)....................................90

7.4 Comparison of the TF to the WF and the PCIM.....................................................96

CHAPTER 8. Conclusions...................................................101

REFERENCES............................................................. 104

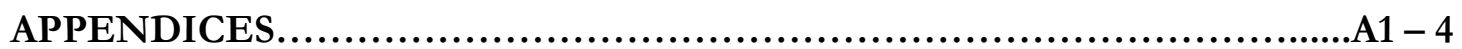

Appendix 1. International and New Zealand Geochronological Timescales........A1

Appendix 2. Biostratigraphy of the Tartan Formation......................................A2

Appendix 3. Full list of geochemical data from Meadows (2008) analyses.........A3

Appendix 4. Full list of geochemical data from this study......................A4

Dylan Meadows, $2009 . \quad$ V 


\section{LIST OF FIGURES}

Figure 1.1 Location map and distribution of exploration wells of the GSB $\ldots \ldots \ldots \ldots \ldots \ldots . \ldots 3$

Figure 1.2 Location map and distribution of exploration wells of the CB............................4

Figure 2.1 Cross section of the Great South Basin...................................11

Figure 2.2 Generalised stratigraphy of the Great South Basin ....................................13

Figure 2.3 Figure 2.3 Generalised stratigraphy of GSB wells studied.........................................19

Figure 2.4 Generalised stratigraphy of the Canterbury Basin........................................20

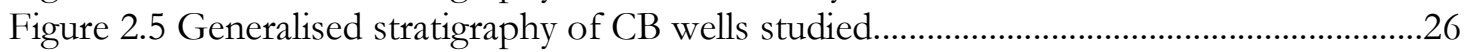

Figure 2.6 Generalised stratigraphy of the East Coast Basin................................28

Figure 3.1 Regional distribution of the Tartan Formation .....................................32

Figure 3.2 Paleogeographic reconstruction of New Zealand during the Late Cretaceous ......34

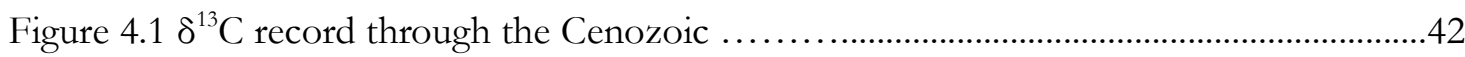

Figure 4.2 Lower Tertiary benthic epifaunal foraminifera variations at ODP $690 \ldots \ldots \ldots \ldots \ldots \ldots . . . . . .46$

Figure 4.3 Late Paleocene $\delta^{18} \mathrm{O}$ and $\delta^{13} \mathrm{C}$ records from ODP site $690 \ldots \ldots \ldots \ldots \ldots \ldots \ldots . . . \ldots 4$

Figure 4.4 Low oxygen in the world's ocean compared with $\delta^{18} \mathrm{O}$ records..................48

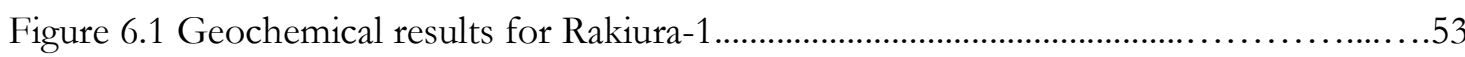

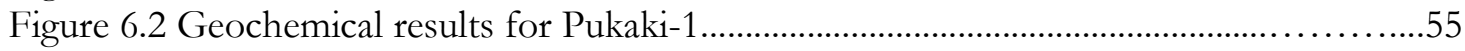

Figure 6.3 Geochemical results for Resolution-1

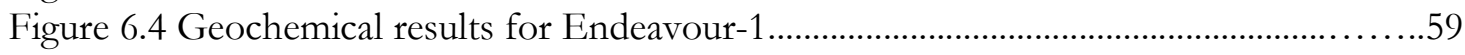

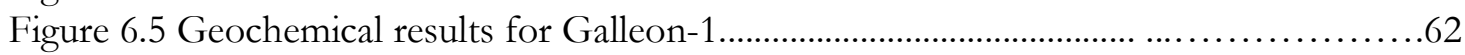

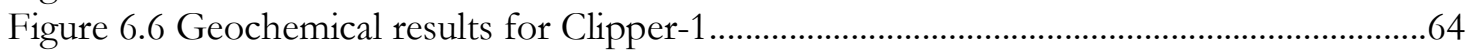

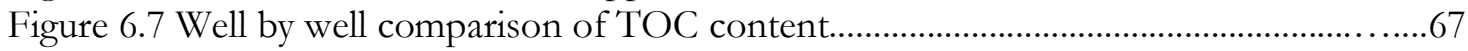

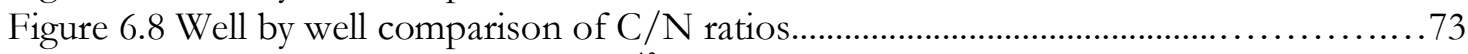

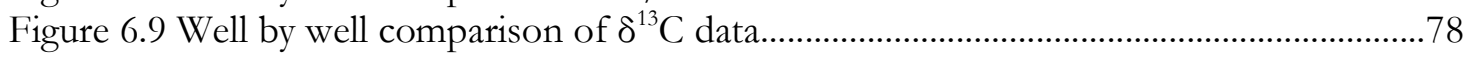

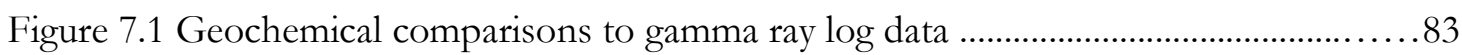

Figure $7.2 \mathrm{C} / \mathrm{N}$ vs. TOC for samples that lie within the Tartan Formation...............................85

Figure $7.3 \mathrm{C} / \mathrm{N}$ vs. TOC for all samples analysed in this study ..........................................86

Figure $7.4 \mathrm{C} / \mathrm{N}$ vs. $\delta^{13} \mathrm{C}$ data for samples that lie within the $\mathrm{TF}$ interval ....................8

Figure 7.5 Comparison of $\mathrm{C} / \mathrm{N}$ vs. $\delta^{13} \mathrm{C}$ data from all samples analysed in this study........88

Figure 7.6 Comparison of TOC vs. $\delta^{13} \mathrm{C}$ data from all samples analysed in this study .........89

Figure $7.7 \mathrm{C} / \mathrm{N}$ vs. $\delta^{13} \mathrm{C}$ data for samples that lie within the Tartan Formation..................92

Figure $7.8 \mathrm{C} / \mathrm{N}$ vs. TOC data for all wells containing Tartan Formation...............................93

Figure 7.9 TOC and $\delta^{13} \mathrm{C}$ data for all wells containing Tartan Formation .......................94

Figure 7.10 Comparison of latest study and 2008 data, TOC vs. $\delta^{13} \mathrm{C}$ for all TF samples .... 95

\section{LIST OF TABLES}

Table 7.1 Peak $\delta^{13} \mathrm{C}$ and TOC values recorded from this and the previous study. .91 
Chapter 1. Introduction

\section{CHAPTER 1}

\section{Introduction}

\subsection{Aim and significance of study}

This study is an investigation of the stable isotope geochemistry of the Tartan Formation and adjacent formations in the Great South and Canterbury basins of southern New Zealand.

The Tartan Formation is mid to Late Teurian (Paleocene) in age and is of interest to the petroleum exploration industry because it is considered to be a lateral equivalent of the mid to Late Teurian Waipawa Formation that is widely distributed throughout most of New Zealand's major sedimentary basins (see Chapter 3). The Waipawa Formation is considered to be an important hydrocarbon source rock, especially in the East Coast Basin; however, discussion of the Tartan Formation as a hydrocarbon source rock is beyond the scope of the present study.

This study focuses on characterisation and correlation of geochemical signatures of the Tartan Formation and parts of the adjacent formations in the Great South and Canterbury basins. The geochemical relationship between the Tartan and Waipawa formations are investigated as well as the global environmental effects during Tartan Formation deposition. Deposition of the Tartan Formation appears to be coincident with at least part of the global Paleocene Carbon Isotope Maximum (PCIM) and may represent a facies that was deposited as a result of environmental changes associated with the PCIM (Hollis et al. 2005).

The present study builds on past research by the author on the Tartan Formation from five exploration wells in the Great South Basin (Meadows, 2008) and is expanded to include two further exploration wells from the Great South Basin and four exploration wells from the Canterbury Basin.

This study, and the study by Meadows (2008), on which the present study is based on, has examined the total organic carbon (TOC) content, $\mathrm{C} / \mathrm{N}$ ratio and $\delta^{13} \mathrm{C}$ values of cuttings and sidewall core samples. The Tartan Formation is defined by its lithology and is recognised by its gamma ray response (Cook et al. 1999). Here, TOC concentrations of the samples are of prime importance, as the organic richness of the samples acts as a proxy to allow formation boundaries to be identified and constrained. The nitrogen content for each sample was also 
Chapter 1. Introduction

recorded to be used in conjunction with the TOC results to give $\mathrm{C} / \mathrm{N}$ ratios. The latter are important for determining the type and source of the organic matter present.

Stable isotope fractionation in chemical reactions is dependant on the bond strength between atoms. Bond strength is dependant on the mass of the atoms on each end of the bond; hence slight mass differences between isotopes will result in bond strength variations in a molecule. This effect causes equilibrium and kinetic differences in a given reaction, with the lighter or heavier isotopic system being preferentially favoured over the other, resulting in fractionation (Anbar and Rouxel, 2007). The type of carbon isotopic fractionation of relevance to this study is biological kinetic fractionation by photosynthesising plants and algae. Implications of this to determinations of the source of the organic content of the samples are discussed in Chapter 7.

Carbon stable isotope geochemistry is used here to identify and define geochemical boundaries within the wells investigated, to allow isotopic characterisation of the Tartan Formation, and to correlate global $\delta^{13} \mathrm{C}$ changes during the Paleocene to Tartan Formation deposition. $\delta^{13} \mathrm{C}$ studies can provide insight into the timing and extent of past environmental perturbations and indicate how conditions have varied throughout geological time. Sources of organic matter within the Tartan Formation are also interpreted, as these data can provide insight into the type of the organic matter present, as different plants, algae and marine bacteria have distinctive isotopic characteristics.

\subsection{Area of study}

The Great South Basin lies off the southeast coast of the South Island of New Zealand (Fig. 1.1). The basin covers an area of approximately $100,000 \mathrm{~km}^{2}$, with water depths ranging from $100 \mathrm{~m}$ to $1250 \mathrm{~m}$ and with a mean depth of $700 \mathrm{~m}$. The northern limit of the basin is taken as $46^{\circ} \mathrm{S}$, and the southern limit is $50^{\circ} \mathrm{S}$. The westernmost part of the basin lies at $168^{\circ} \mathrm{E}$, and it extends east to $172^{\circ} \mathrm{E}$ (Cook et al. 1999).

Dylan Meadows, 2009. 


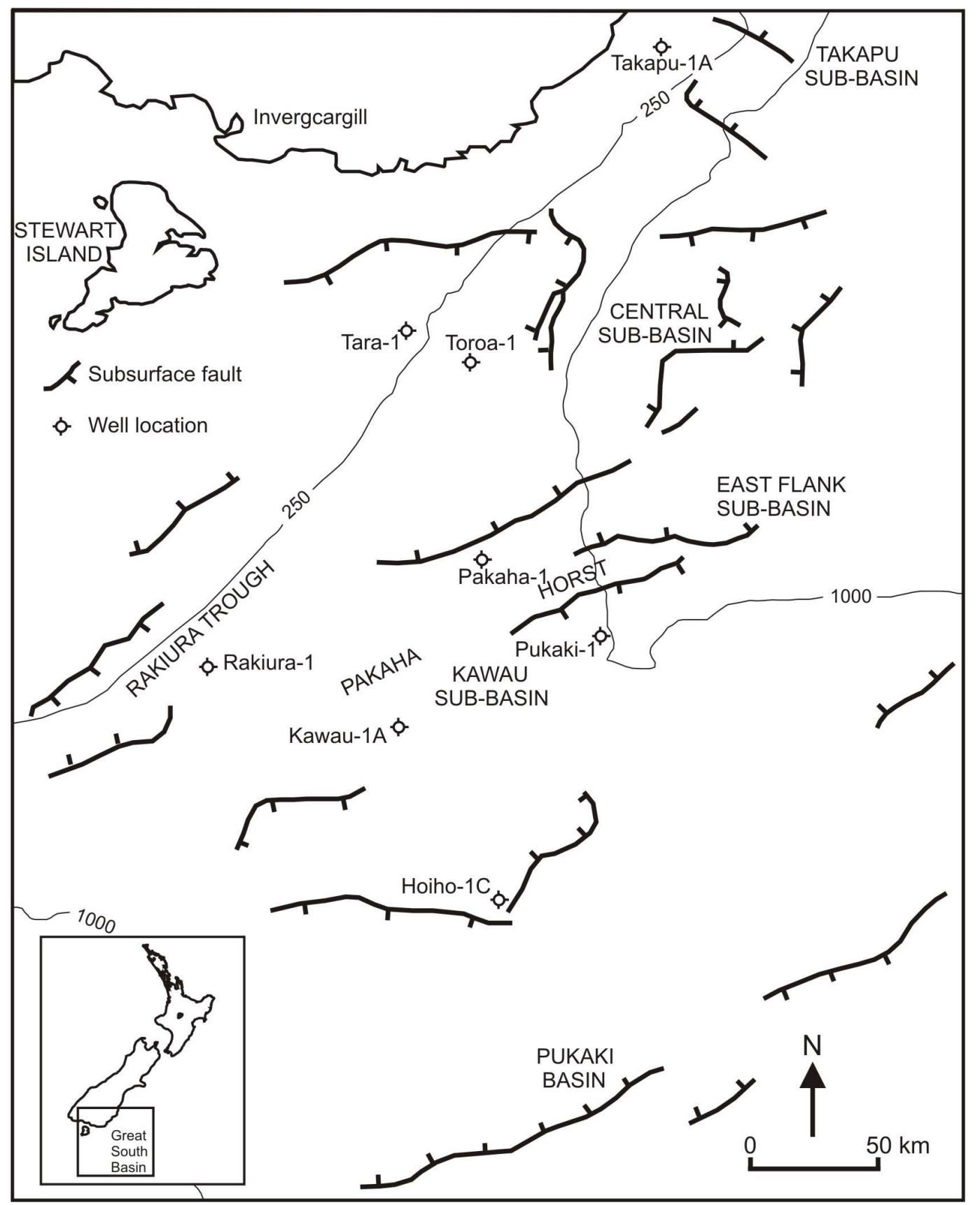

Figure 1.1 Location map and distribution of petroleum exploration wells of the Great South Basin (Redrawn from Crown Minerals, 2008a).

The Canterbury Basin extends from the onshore Canterbury Plains over an extensive offshore region east of the South Island of New Zealand (Fig. 1.2). The basin covers an area of approximately $55,000 \mathrm{~km}^{2}$, of which around $30,000 \mathrm{~km}^{2}$ is offshore (Killops et al. 1997). The northern limit of the basin is taken as $44^{\circ} \mathrm{S}$ and the southern limit approximately $46^{\circ} \mathrm{S}$.

Dylan Meadows, 2009. 
Chapter 1. Introduction

The westernmost area of the basin lies around $171^{\circ} \mathrm{E}$, and it extends east to $174^{\circ} \mathrm{E}$ (deduced from Fig. 1, Killops et al. 1997).

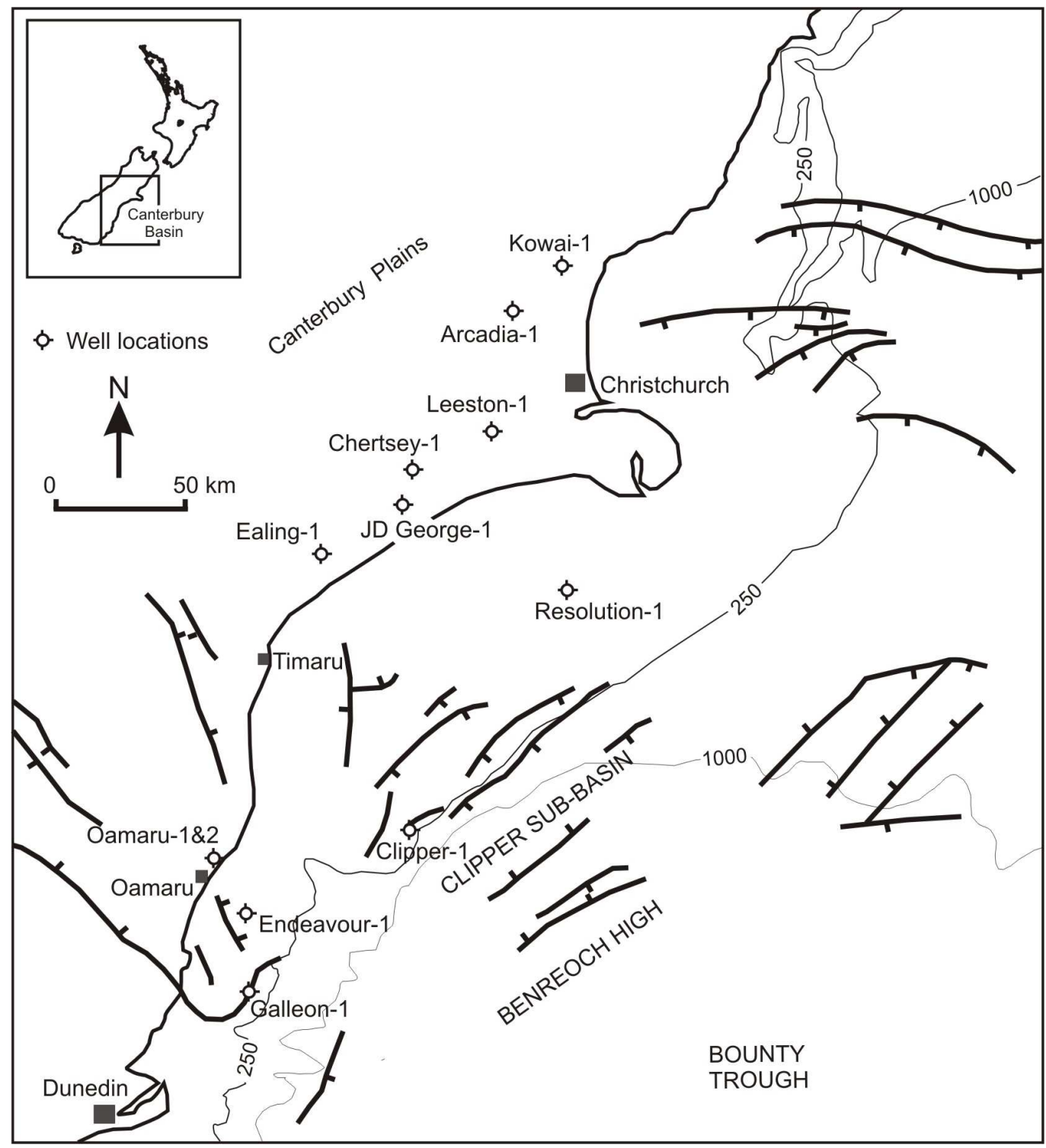

Figure 1.2 Location map and distribution of petroleum exploration wells of the Canterbury Basin (Redrawn from Crown Minerals, 2008b).

\subsection{Exploration history}

The Great South Basin was initially defined by geophysical surveys carried out by the Sea Hunt exploration group. Between 1968 and 1983 more than 30,000 line km of seismic 
Chapter 1. Introduction

reflection data were collected (Cook et al. 1999), with eight petroleum exploration wells drilled between 1976 and 1984. During 1976 and 1977, the Sea Hunt consortium drilled four wells in License 863 (Toroa-1, Pakaha-1, Kawau-1A, and Hoiho-1C; Fig. 1.1). In 1978 Petrocorp drilled two further wells, Tara-1 and Takapu-1A. The Placid Oil Company drilled Rakiura-1 and Pukaki-1 in 1983 and 1984 respectively. The four offshore petroleum exploration wells (Endeavour-1, Resolution-1, Galleon-1, and Clipper-1; Fig. 1.2) of the Canterbury Basin were drilled between 1970 and 1985 by BP Shell Todd (Canterbury) Services Limited.

\subsection{Previous studies of the Great South and Canterbury basins}

Great South Basin

The first comprehensive published accounts of the Great South Basin were compiled by Carter (1988a, b). Carter (1988a) defined a formal stratigraphic framework for the eastern South Island and placed the Great South Basin stratigraphy within this framework (Cook et al. 1999). Beggs (1993) proposed a revised stratigraphy for the Great South Basin, and Raine et al. $(1993,1994)$ provided a comprehensive review of the foraminiferal and palynological biostratigraphy for seven of the petroleum exploration wells in the basin. Killops et al. (1997) used geochemistry to report the petroleum potential and oil-source correlation in the Great South and Canterbury basins. Cook et al. (1999) have published a compilation of the Great South Basin petroleum industry exploration data and information from petroleum reports, including well logs, as one of the IGNS Cretaceous-Cenozoic geology monograph series. Well completion reports for each of the wells investigated from the Great South Basin (Placid Oil Co. 1984 a, b; Hunt International Petroleum 1977 a, b, c; 1978, a b) were useful for identifying structural and stratigraphical features of the basin and of each of the wells examined. The age and depositional environments of the Tartan Formation and enclosing formations were examined by Schioler and Roncaglia (2008) using detailed palynological analyses of the sidewall core samples from Great South Basin exploration wells.

As previously mentioned, the present study builds on previous research undertaken by the author (Meadows, 2008). That work involved $\delta^{13} \mathrm{C}$, TOC and $\mathrm{C} / \mathrm{N}$ examination of the Tartan Formation from five exploration wells in the Great South Basin. The research focused on the geochemical characteristics of the Tartan Formation and enclosing formations, the sources of organic matter within these formations and correlation to the 
Chapter 1. Introduction

Waipawa Formation, a lithostratigraphic equivalent found in several other major sedimentary basins around New Zealand. A digital copy of Meadows (2008) is included with this dissertation.

\section{Canterbury Basin}

A detailed list of past studies of the Canterbury region and Canterbury Basin is given in Field and Brown (1989). Previous studies of the Canterbury Basin that are of greatest importance to the present research include the individual well completion reports for each well examined: Milne (1975); Wilding and Sweetman (1971); Hawkes and Mound (1984); and Wilson (1985), and the publication by Field and Brown (1989). Petroleum Reports by Anderton et al (1982); Mound and Pratt (1984); Simpson (1993); Shell BP Todd (1984); Olson (1996) were all useful in presenting detailed information on the tectonic history, stratigraphy, geochemistry, and petroleum geology of the Canterbury Basin.

\subsection{Outline of this study}

Chapter 1 provides a brief introduction into the aims and significance of this study together with a basic history of exploration and research of the Great South Basin. Ages are discussed in terms of both international and local subdivisions (Appendix 1; derived from Geological and Nuclear Sciences, 2003). Chapter 2 is a compilation of data that detail the stratigraphy and a brief structural history of areas of the basin relevant to this study. The general stratigraphy of the East Coast Basin is included here, and used as a comparison to the stratigraphy of the Great South and Canterbury basins and as a basis for discussion in later chapters. Chapter 3 details the nomenclature, distribution, depositional environments, characteristic lithological features and age of the Tartan Formation. Environmental conditions that are likely to have contributed to the deposition of the Tartan and Waipawa formations and equivalents found elsewhere in New Zealand are described in Chapter 4. Methods and analytical procedures employed in this study are described in Chapter 5. The results from mass spectrometry analyses are described and compared in Chapter 6 . The main discussion and implications for the geochemical data are compared to other literature and are interpreted in Chapter 7, and important findings are summarised in Chapter 8. 
Chapter 2. Geological Setting of the Great South and Canterbury basins

\section{CHAPTER 2}

\section{Geological Setting of the Canterbury and Great South Basins}

\subsection{Plate Tectonics}

\subsubsection{Tectonic evolution}

\section{Pre-Gondwanaland separation}

Gondwanaland began to break up during the mid-Jurassic. Initial detachments from the supercontinent involved India, South America and Africa, while the section that contained Antarctica, Australia and New Zealand remained intact at this time (Anderton et al. 1982). Prior to the Late-Cretaceous the New Zealand continent, while still part of the Gondwana landmass, was adjacent to the Eastern Ross Sea Basin and Marie Byrd Land regions of Antarctica. During this time, the Bounty Trough was closed which caused the Chatham Rise to lie alongside the northern Campbell Plateau (Mound and Pratt, 1984).

The Rangitata II Orogeny was the final orogenic event prior to the break-up of eastern Gondwana. This event was the result of subducted oceanic crust beneath the New Zealand section of Gondwana and an associated accretion of a wedge of marine sediments on the seaward facing side of the continent (Mound and Pratt, 1984). The Rangitata II Orogeny was terminated by the initial breakup of Gondwanaland around the mid-Cretaceous (Shell BP Todd, 1984). This orogenic event ended with a period of stability for the Gondwana coastal areas, with gentle uplift and peneplanation of folded and metamorphosed rocks that were deformed during the Jurassic and Early-Cretaceous. The erosion of the peneplain continued until the Late-Cretaceous (Mound and Pratt, 1984).

\section{Separation of New Zealand from Gondwana}

Separation of the Antarctic-Australia-New Zealand landmass from Gondwanaland represents the final phase of fragmentation of the Gondwana Supercontinent (Mutter et al. 1985).

The New Zealand continent broke away from the Antarctic-Australian landmass during the mid-Cretaceous ( $100 \mathrm{Ma}$ ). Early phases of this rifting set the basement terrain of New Zealand into an extensional regime. This phase resulted in crustal attenuation and reduced 
Chapter 2. Geological Setting of the Great South and Canterbury basins

the continental crust thickness (from around $30 \mathrm{~km}$ to $20 \mathrm{~km}$ ) (Anderton et al. 1982). Early Cretaceous plutons associated with the last phase of breakup resulted in the formation of large horst blocks and deep grabens (Anderton et al. 1982).

Widespread rifting around New Zealand during the period 105 to $80 \mathrm{Ma}$ was associated with the final stage of Gondwana breakup. This involved the separation of: the Lord Howe Rise from Australia, which formed the Tasman Sea; East Antarctica from Australia, forming the Southeast Indian Ocean; and the Campbell Plateau from Marie Byrd Land, forming the South Pacific Ocean approximately $90 \mathrm{Ma}$ (Cook et al. 1999).

Separation of Australia from East Antarctica was earlier than Australia-Lord Howe Rise and Campbell Plateau-Marie Byrd Land separation, with evidence for early rift phases during the Late Jurassic to Early Cretaceous. This was followed by the onset of slow spreading on the Southeast Indian Ocean Ridge around $96 \mathrm{Ma}$ (Cook et al. 1999).

Based on magnetic anomaly data Mutter et al. (1985) have suggested that $86 \mathrm{Ma}$ was the time of the initiation of spreading in the Tasman Sea, the initiation of spreading between New Zealand and Antarctica, and the time of major plate boundary reorganisations in the Indian Ocean. Veevers (1986) stated that sea-floor spreading between Australia and Antarctica began at or prior to $86 \mathrm{Ma}$.

The Tasman Sea began to open at its southwest end adjacent to Tasmania and the Challenger Plateau. Seafloor spreading propagated in a northwest direction (Cook et al. 1999).

Initial movements along normal faults began in the mid-Cretaceous with rift valleys and grabens developing on the New Zealand continent, parallel to the axis of rifting. This represents the change from compressional to extensional tectonics in the area to facilitate the extension (Anderton et al. 1982; Mound and Pratt, 1984). This extension divided the Campbell Plateau into several large depocenters, such as the Bounty Trough, which was initiated as a rift valley during this time, spreading the Campbell Plateau from the Chatham Rise (Anderton et al. 1982). The onset of tension across the Campbell Plateau and the Canterbury Basin reactivated some old Rangitata fault trends and created new fault lines. The main axis of tension across Campbell Plateau was controlled by the spreading between New Zealand and Antarctica, and also spreading in the Bounty Trough (Mound and Pratt, 1984). The Bounty Trough represents a failed rift arm that may have formed just before or during the earliest stages of seafloor spreading south of the Campbell Plateau. The trough 
Chapter 2. Geological Setting of the Great South and Canterbury basins

may have initially formed prior to the Cretaceous, but was a region of intense Cretaceous crustal thinning, merging its eastern end with Cretaceous Oceanic crust (Cook et al. 1999).

New Zealand was a single continental block that had not began to break into its current microplates between 85 and $83 \mathrm{Ma}$. This block separated from the Antarctic-Australia landmass as a whole, moving away with the Pacific Plate. As spreading commenced, the New Zealand continental terrain of the Campbell Plateau faced the opening sea to the south (east in its present rotated location). Some further extensional faulting took place, brought on by rifting; however, basement topography was not significantly altered after this time (Anderton et al. 1982).

Towards the end of the Cretaceous period, spreading was progressing at different rates along the line of separation from the Antarctic-Australia block. The northern section of the Tasman Sea opened slowly while the southeastern section of the Ross Sea opened relatively rapidly. This created an anticlockwise rotation of New Zealand from Gondwana. The differential movement may have led to internal rotation within the Campbell Plateau itself, possibly initiating the dextral movement on the fault system which underlies the present shelf edge. Towards the end of the mid-Cretaceous many of the smaller fault movements ceased due to the transition from rifting to drifting. The larger faults continued to show movement; however, their throws were much less than during the rifting phase. By the end of the Cretaceous normal fault movement had almost entirely ceased, but did continue locally in the Great South and Canterbury basins (Anderton et al. 1982).

\section{Post Gondwana separation}

Plate motions in the Tasman and South Pacific region during the 80-53 Ma period were dominated by sea floor spreading (Cook et al. 1999). During the Late Cretaceous to Early Tertiary, as the New Zealand continental block drifted away from the site of lithospheric upwelling and heating, it cooled and underwent thermal contraction which resulted in subsidence of the continental margin and subsequent transgression of local seas (Gibbons and Fry, 1986.).

In central parts of the Campbell Plateau gentle uplift occurred during the mid to Late Paleocene. This uplift stage could have been connected with continued rotation of the entire Campbell Basin block (Anderton et al. 1982). 
Chapter 2. Geological Setting of the Great South and Canterbury basins

The New Zealand block continued to move as a single unit, but the termination of spreading in the Tasman Sea 60-55 Ma, as identified from magnetic anomaly data, locked the Lord Howe Rise onto the Indo-Australian Plate. At the same time, rifting between Australia and Antarctica commenced. Spreading between the Australian and Antarctic blocks occurred 56-33 Ma on the Southeast Indian Ocean Ridge. In this area the Pacific and Indo-Australian plates began moving away from Antarctica simultaneously. Spreading rates and direction of movement were slightly different on the Southeast Indian Ocean Ridge and the PacificAntarctic (Ross Sea) Ridge, causing strain on the New Zealand block (which became caught in between) and on the ocean-ocean boundaries north of New Zealand (Anderton et al. 1982).

Curved fractures zones at the Pacific Ridge indicate a significant change in the direction of spreading during the period 53-43 Ma (Cande et al. 1995). This change in spreading direction was accompanied by a significant reduction in the rate of spreading (Cande et al. 1995).

India collided with Asia during Late Eocene to Early Oligocene time (38 Ma). The resultant reorganisation of plate motions to accommodate the abrupt termination of relative northwest movements of the Indo-Australian Plate changed the direction of intersection with the Pacific Plate (Anderton et al. 1982; Shell BP Todd, 1984). A consequence of this was the immediate onset of subduction zone and arc formation north of New Zealand, and the rupture of the New Zealand continental block. This led to the initiation of the Alpine Fault around/or shortly after this time (36 Ma), and began dextral strike-slip separation of the newly formed Lord Howe and Campbell microplates (Anderton et al. 1982; Hawkes and Mound, 1984).

The stable drift conditions that prevailed during the Oligocene ended in the Miocene with the onset of subduction to the north of New Zealand and oblique compression to the south (Mound and Pratt, 1984). The mid-Miocene event is represented by the onset of the Kaikoura orogeny, recent uplift, and continued metamorphism of the Southern Alps flysch sequence. Spreading rates on the Pacific-Antarctic (Ross Sea) Ridge became slower in the southwest, towards the Macquarie Ridge, and faster in the northeast where it is offset from the East Pacific Rise spreading centre. This differential spreading created an anticlockwise rotation of the Campbell microplate. The subsequent microplate interaction caused a strong compressive component of movement on the Alpine Fault, which consequently led to uplift of the Southern Alps (Anderton et al. 1982). 
Chapter 2. Geological Setting of the Great South and Canterbury basins

The paleogeography of the New Zealand region is described and illustrated in detail by Cook et al. (1999; pages 99-103, figure 5.1).

\subsubsection{Structure of the Great South Basin}

The Great South Basin is a mid to Late Cretaceous intra-continental rift basin that formed as a result of regional extension in association with the opening of the Tasman Sea and separation of Australia from Antarctica (Olson, 1996). The structural history of much of the basin consists of initial syn-rift subsidence followed by Tertiary thermal subsidence (Olson, 1996).

The structure is principally governed by a system of sub-parallel normal faults that trend in a northeast-southwest direction, and the basin is comprised of a series of grabens, half grabens and tilted horsts (Anderton et al. 1982) that formed between the South Island of New Zealand and the Campbell Plateau. The deeper segments of the basin are comprised of five major structural provinces: the Central Graben, the Pakaha and associated horsts, the East Flank Sub-basin, the Rakiura Trough, and the Kawau Depression. These features are almost entirely aligned with and controlled by the above-mentioned fault patterns (Anderton et al. 1982).

Figure 2.1 displays a generalised cross section of the Great South Basin, which includes some of the more prominent features and the relative proximity of some of the exploration wells that have been drilled in the basin.

\section{SCHEMATIC SECTION - MID CRETACEOUS - PALEOCENE GREAT SOUTH BASIN, NEW ZEALAND}

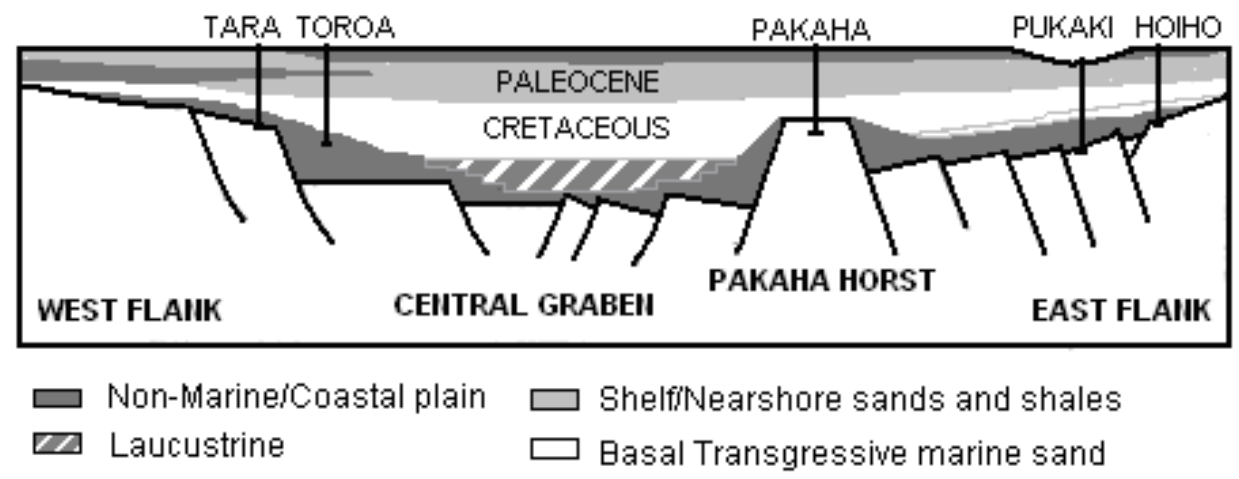

Figure 2.1 Cross section of the Great South Basin. Modified from Olson (1996).

Dylan Meadows, 2009. 
Chapter 2. Geological Setting of the Great South and Canterbury basins

The Central Graben floor is controlled by a series of relatively passive northeast-trending grabens and horsts which become increasingly complex towards the strike-slip fault zone on the northwest flank of the basin. The northwest flank has continued to be affected by dextral strike-slip faulting and this was responsible for post-Oligocene inversion of relief anticlinal features in this area (Anderton et al. 1982).

The East Flank Sub-basin is much smaller in area than the Central Graben and is dominated in its northwestern part by a series of east-northeast aligned half grabens that are tilted to the north-northwest and bounded by normal faults that are downthrown to the south-southeast. In southern parts of the province the normal faulting slopes to the opposite direction (Anderton et al. 1982).

\subsubsection{Structure of the Canterbury Basin}

The Canterbury Basin is bounded at its northern flank by the Chatham Rise, and to the northwest by the Bounty Trough (Killops et al. 1997). To the west, the basin extends onshore to the South Island of New Zealand, and is contiguous with the Great South Basin to the south (Baillie and Uruski, 2004).

The basin began to form during the early to mid-Cretaceous as a result of New Zealand splitting from Gondwana. This separation caused extensional tectonism that led to graben and half graben development as well as the formation of many structural highs in the form of horsts. Mid-Cretaceous extensional tectonism (a graben forming process) produced fault angle depressions that have been filled with over $4 \mathrm{~km}$ of sediment in some areas of the basin. Basement rocks were deformed during the Rangitata I and II orogenies between the Late Triassic and Early Cretaceous (Field and Browne, 1989).

Normal faults that formed during the Cretaceous are the dominant fault pattern in the Canterbury Basin. These faults typically trend in a northeast-southwest direction and are generally downthrown to the southeast (Field and Browne, 1989).

The Canterbury Basin consists of two main depocentres which developed in response to early to mid Cretaceous rifting. The northern depocentre is the offshore Clipper Sub-basin bound by the Endeavour High to the northwest and the Canterbury Rise to the southeast. The southern depocentre is the Central Trough of the Great South Basin as the southern sector of the Canterbury Basin is contiguous with the Great South Basin (Baillie and Uruski, 2004).

Dylan Meadows, 2009. 
Chapter 2. Geological Setting of the Great South and Canterbury basins

\subsection{Stratigraphy of the Great South and Canterbury basins}

\subsubsection{The Great south Basin}

A detailed account of the stratigraphy of the Great South Basin can be found in Cook et al. (1999); the following is a summary of the more important points from Cook et al. (1999) that are relevant to this study.

Figure 2.2 is a generalised representation of the stratigraphy of the Great South Basin.

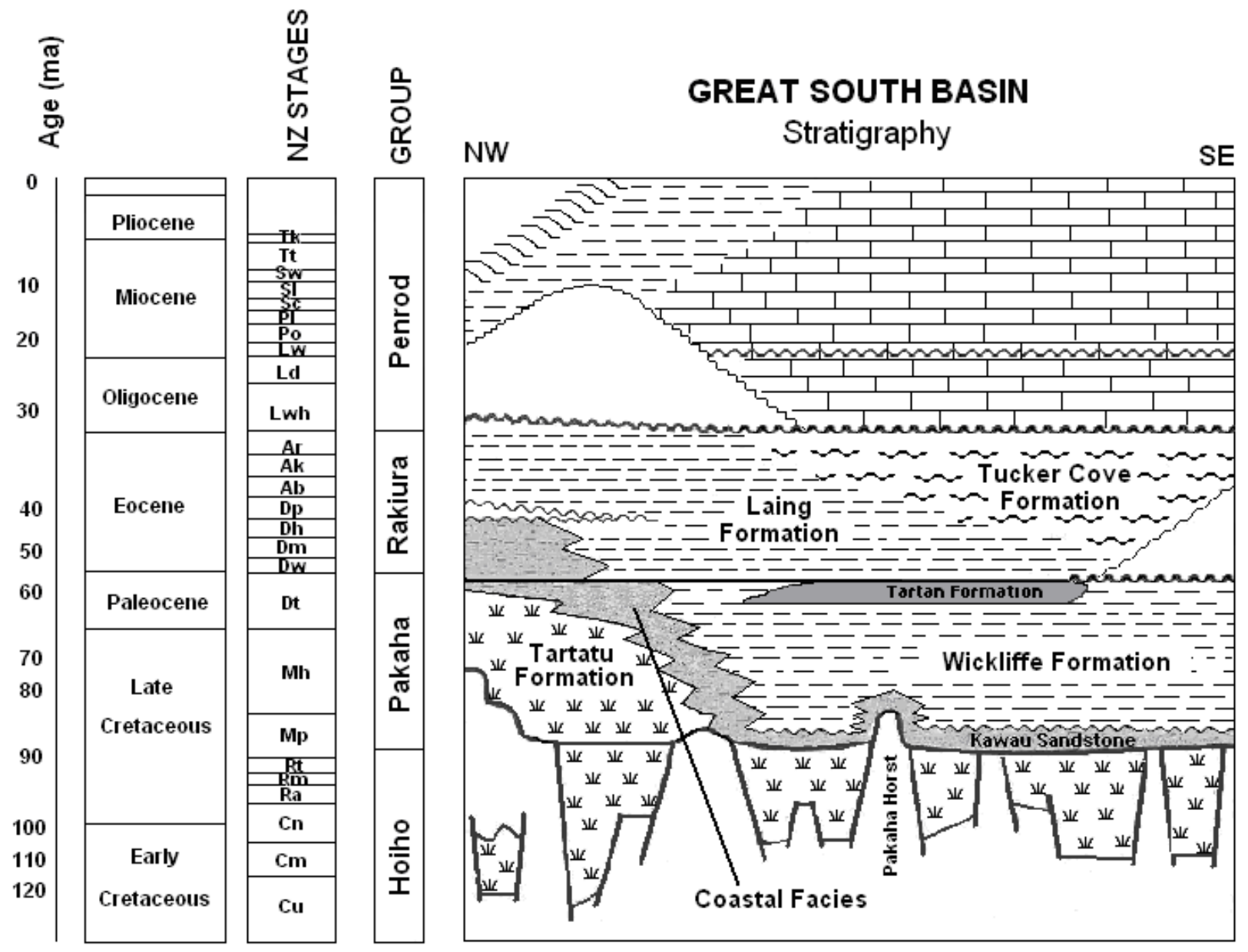

Figure 2.2 Generalised stratigraphy of the GSB (Modified from Cook et al. 1999).

Cook et al. (1999) have divided the stratigraphy of the Great South Basin into four lithostratigraphic groups: the Hoiho, Pakaha, Rakiura and Penrod groups.

Dylan Meadows, 2009. 
Chapter 2. Geological Setting of the Great South and Canterbury basins

\section{Hoibo Group}

The Hoiho Group is the oldest group recognised in the Great South Basin and is interpreted to be of mid to Late Cretaceous [Ngaterian (Cn) to Piripauan (Mp)] age. The lithology of the group consists of sandstones, shales, conglomerates and coals.

The Hoiho Group consists of a succession of non-marine clastic facies that can be subdivided into three separate time components: the Clarence Series ( $\mathrm{Cu}-\mathrm{Cn})$, Raukumara Series (Ra-Rt), and the early Piripauan Stage (Mp). The Clarence Series represents the basal unit and is characterised by variable-amplitude reflectors with a discontinuous and wedge shaped geometry suggesting fluvial valley fill, and adjacent high-amplitude, steeply dipping reflectors that are interpreted to be fault scarp fans along the graben margins.

The middle unit is the Raukumara Series and seismic facies within the unit are highly variable which is interpreted to indicate a dominance of terrestrial paleoenvironments. The low-amplitude, discontinuous reflectors are believed to be lacustrine facies, while medium to high-amplitude and variably continuous reflectors are interpreted as coal measures.

The upper unit of the Hoiho Group, which contains sediments from the Piripauan Stage, has a chaotic, variable-amplitude seismic facies in the Eastern-Flank Sub-basin which has been interpreted to be deposits formed of reworked and winnowed earlier Cretaceous sediments that resulted from a deficiency of sediment supply coupled with wave and tidal action during periods of transgression.

The deposition of the Hoiho Group took place in a series of normal faulted depressions and sub-basins. Steeply dipping reflectors close to faults are indicative of widespread alluvial fan sedimentation. Distal fault scarps, fluvial and coal measure facies are interpreted to be the result of deposition in braided floodplain and lacustrine environments.

\section{Pakaha Group}

Overlying the Hoiho Group is the Pakaha Group, which ranges from Late Cretaceous to Paleocene [Late Piripauan (Mp) to Late Teurian (Dt)] in age and includes several formations. The base of the Pakaha Group is the Kawau Sandstone, which is overlain by the Wickliffe Formation, and is overlain by the Taratu Formation, which is in turn overlain by the Tartan Formation at the top of the group where Tartan Formation is present. 
Chapter 2. Geological Setting of the Great South and Canterbury basins

Sediments in the Pakaha Group were deposited after most normal faulting had rapidly begun to subside, and as a result, marine transgression continued. To the west of the basin was an eastward progression of depositional environments ranging from fluvial and coastal plain with extensive coal swamps, paralic, to shallow marine conditions. The major drainage systems formed alluvial fan complexes. The eastern margin gradually subsided to shelf depths (Cook et al. 1999; see Enclosure 1, maps 5 and 6 from that publication), and in the East Flank Sub-basin, carbonates began to accumulate as a result of reduced sediment supply.

The Kawau Sandstone is a white to grey, medium coarse, friable sandstone. It ranges in age from Piripauan (Mp) to Haumurian (Mh) (Raine et al. 1993). The formation is interpreted to have been deposited in a shallow marine, nearshore setting.

The Wickliffe Formation is bound by unconformities at both the base and the top, and ranges in age from Piripauan to Late Teurian (Raine et al. 1993). The formation generally consists of soft to firm, fissile, light grey shales and clays with subordinate darker brown shale and is glauconitic in places. Based on fossil faunas identified in the south and west of the basin within the Wickliffe Formation, a nearshore to inner-shelf marine environment, generally with restricted circulation depositional environment is inferred (Raine et al. 1993). The most widespread marine conditions seem to have been in about the Late Cretaceous, followed by shallowing to coastal environments during the Paleocene. The Wickliffe Formation has similar characteristics to the Whangai Formation found around the East Coast region of the North Island.

The top of the Taratu Formation is defined by the transition to marine facies of the Wickliffe Formation which interfingers laterally with the Taratu Formation. The Taratu Formation consists of interbeds of quartzose grit, pebble conglomerates, sandstone and shales with common coal measures. The sandstones are light brown, and fine to coarse grained, while the shale is chocolate brown, firm to blocky, micaceous and very carbonaceous. The coals range in rank from lignite to sub-bituminous. The base of the formation is at least Piripauan in age and possibly Late Haumurian at the top of the formation. Its deposition in the Great South Basin is believed to have taken place on a lower coastal plain, and it is possible that some of the coal measures were influenced by brackish conditions (Raine et al. 1994; Wilson and McMillan, 1996). 
Chapter 2. Geological Setting of the Great South and Canterbury basins

The uppermost member in this group is the formation of most importance to the present study. The Late Paleocene (Late Teurian) Tartan Formation is a dark brown, firm, carbonaceous, slightly calcareous, highly micaceous, and slightly glauconitic shale. The Tartan Formation very closely resembles the Waipawa Formation (also referred to as Waipawa Black Shale) widely found in many basins around New Zealand, including the Canterbury Basin (see Chapter 3) and is interpreted to be its equivalent. Deposition of the Tartan Formation is likely to have been similar to that of the Waipawa Formation but it was possibly deposited in a shallower environment in the Great South Basin than in other basins around New Zealand where it has been identified.

\section{Rakiura Group}

The Rakiura Group was deposited during the Eocene [with the lowermost formation deposited during the Waipawan (Dw) and the uppermost formation during the Runangan (Ar)]. The group is made up of the Laing and Tucker Cove formations.

In southern parts of the basin, the group is defined by an unconformity or by the base of a condensed section. In central parts of the basin the correlative surface lies immediately above the Tartan Formation, and is typically characterised by a sharp upward increase in carbonate content. The top of the group is defined by a regional unconformity towards central and northwestern parts of the basin, with overlying Penrod Group sediments progressively onlapping it from the west. In the Central Sub-basin, the boundary is characterised by a change in lithology from siltstones and clays of the Laing Formation to chalks or foraminiferal oozes of the Penrod Group. In the southeastern part of the basin, the Tucker Cove Formation overlies the Laing Formation and there is a change from the limestone of Tucker Cove Formation to foraminiferal oozes and chalks of the overlying Penrod Group.

Seismic facies appearing in the Rakiura Group are interpreted to represent slope-basin floor fans and turbidite fans, bathyal carbonates and clastics, and submarine canyon deposits.

The base of the Rakiura Group corresponds to the transition from restricted marine circulation with organic-rich shale deposition in the Late Paleocene to open ocean conditions. Pelagic carbonate sediments of the Tucker Cove Formation were deposited in the southeast of the basin during the earliest Eocene, and extended progressively to the west. From the Early Eocene, a broad prograding wedge formed at the eastward-curving shelf 
Chapter 2. Geological Setting of the Great South and Canterbury basins

margin, from which a slope-basin floor fan complex developed, probably in outer shelf to upper bathyal depths (Raine et al. 1993). Submarine canyon and valley systems appeared at bathyal depths from at least the Early Eocene.

The base of the Laing Formation is defined by the regional unconformity to the southeast at the base of the Rakiura Group and is interpreted to be of Late Teurian age. Siltstones within the formation are laterally continuous with marls of the Tucker Cove Formation. In central and southeastern parts of the basin, there is an upward transition from the Laing Formation to the Tucker Cove Formation which is defined by a change from clastic to carbonate-dominated sedimentation.

The Laing Formation extended over most of the Great South Basin in the Early Eocene but by the end of the Eocene, clastic sedimentation was restricted to areas in the west of the basin. The Laing Formation in western parts of the basin consists of interbedded sandstones and siltstones, which are moderately calcareous, and contain glauconite and traces of pyrite. To the east, the formation consists of shales and calcareous clays. The Laing Formation is interpreted to have been deposited in a shelf to upper bathyal setting. Raine et al. (1994) provide evidence for gradual deepening from inner to mid-shelf depositional settings to the west of the basin during the Early Eocene, whereas an outer shelf to upper bathyal setting was present in the east of the basin. The Laing Formation is lithologically similar to the Wanstead Formation of the East Coast Basin, and is of similar age (Meadows, 2008).

The base of the Tucker Cove Formation is defined as the base of carbonate-rich marls and foraminiferal limestones which overlie the unconformity recognised near Late Paleocene strata. The top of the formation is the regional unconformity that separates the Rakiura Group from Penrod Group sediments. The Tucker Cove Formation consists of soft to firm, white to light grey, fine-grained, foraminiferal limestone with chert nodules and traces of pyrite and glauconite. The unit ranges in age from Waipawan (Dw) to Runangan (Ar). Deposition of the formation ranged from outer-shelf to mid-bathyal depths with open oceanic conditions in surface waters.

\section{Penrod Group}

The Penrod Group is the uppermost stratigraphic unit in the Great South Basin, with the upper limit of the unit representing the present sea floor. The lower boundary is a regional unconformity that is of Late Eocene or earliest Oligocene age. Oligocene strata lap onto the 
Chapter 2. Geological Setting of the Great South and Canterbury basins

western margin where moderate to high-amplitude, continuous, slightly wedge-shaped seismic facies suggest deposition in deep water with restricted clastic sediment supply.

The depositional environment in the southern and eastern parts of the basin is inferred to have been under bathyal depths. Along the northwestern margin of the basin, increased sediment supply during Miocene-Recent time formed a shelf wedge that is over $800 \mathrm{~m}$ thick.

\subsubsection{Stratigraphy and Structure of GSB Petroleum Exploration Wells Sampled}

The basin floor that upper Cretaceous and Tertiary sediments were deposited upon was a peneplained series of anticlinal mountains of Triassic and Jurassic age. Periodic structural uplift throughout the Tertiary resulted in uplift and drape of the Tertiary sediments over the buried lower and mid-Mesozoic mountains that had a northwest-southeast trend. Seismic mapping shows that the greatest uplift, and hence structural drape, took place in the lower Tertiary (Cook et al. 1999).

The generalised stratigraphy of the two wells from the Great South Basin investigated in the present study are presented in Figure 2.3. 
Chapter 2. Geological Setting of the Great South and Canterbury basins

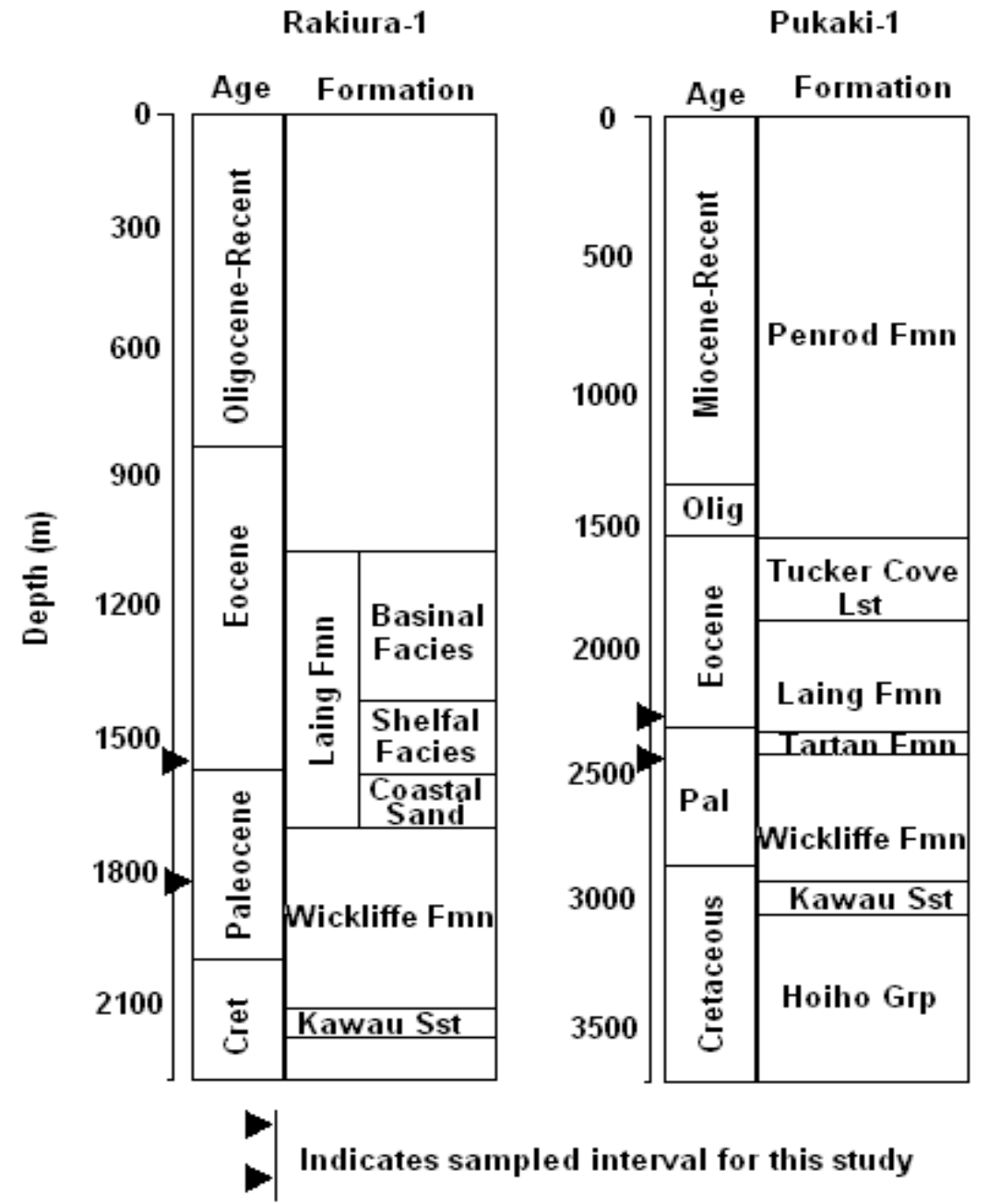

Figure 2.3 Generalised stratigraphy of Rakiura-1 and Pukaki-1.

Rakiura-1

The Rakiura-1 petroleum exploration well is located adjacent to the Rakiura Trough in the southwest quadrant of the Great South Basin (Fig. 1.1) under approximately $650 \mathrm{~m}$ of water. The Rakiura structure is essentially a normal faulted, basement-induced drape structure. The Rakiura Trough is effectively a southwestward extension of the Central Graben, but is separated by a basement high trending in a northwest-southeast direction. The structure has a closure area of up to $140 \mathrm{~km}^{2}$ and a vertical closure of approximately $300 \mathrm{~m}$ (Placid Oil Co. 1984b).

Dylan Meadows, 2009. 
Chapter 2. Geological Setting of the Great South and Canterbury basins

\section{Pukaki-1}

The Pukaki-1 petroleum exploration well is located in the East Flank Sub-basin in the southeast section of the Great South Basin (Fig. 1.1) under approximately $880 \mathrm{~m}$ of water. The structure is the result of compaction of sediments draped over a complexly faulted basement. There is approximately $140 \mathrm{~km}^{2}$ of closure area, and vertical closure of approximately $285 \mathrm{~m}$ (Placid Oil Co. 1984a). Vertical uplift is evident from seismic crosssections of the Pukaki structure from at least the top of the Cretaceous to the acoustic basement.

Other wells in the Great South Basin

A full account of the stratigraphy and structural features of the six other exploration wells of the Great South Basin can be found in Meadows (2008; Chapter 2).

\subsubsection{The Canterbury Basin}

A detailed account of the stratigraphy of the Canterbury Basin can be found in Field and Browne (1989), and petroleum reports from data acquired and wells drilled in the basin. The following is a summary of the more important points from their work that are relevant to this present study.

Figure 2.4 is a generalised representation of the stratigraphy of the Canterbury Basin. 


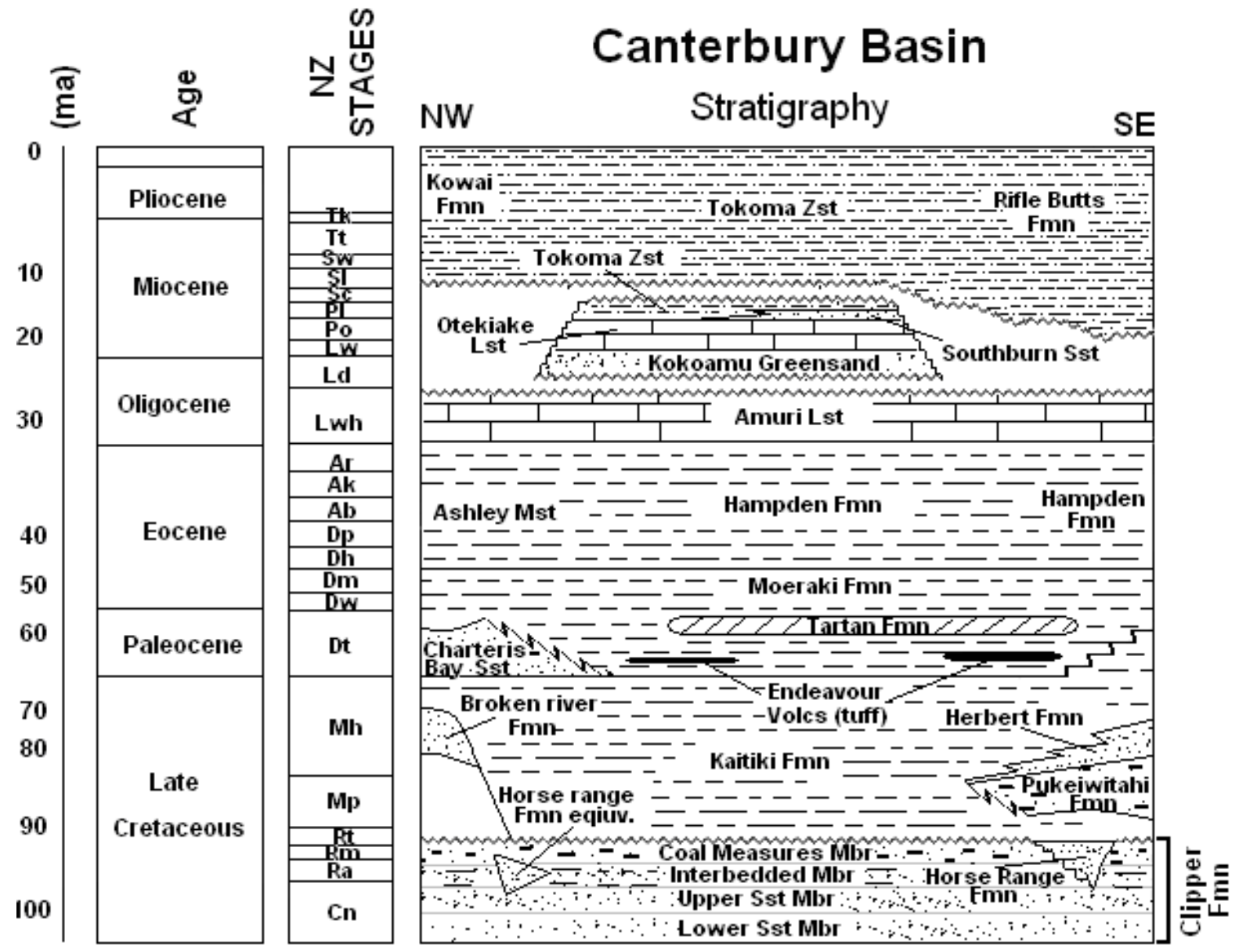

Figure 2.4 Generalised stratigraphy of the Canterbury Basin (Modified from Crown Minerals, 2008c; Field and Brown, 1989).

The oldest recognised sediments in the Canterbury Basin are those of the Clipper Formation, which has been tentatively assigned to the mid-late Cretaceous Clarence and Raukumara Series [approximately Ngaterian (Cn) to Teratan (Rt)] (Hawkes and Mound, 1984).

The following description of the Clipper Formation has been summarised from Hawkes and Mound (1984) unless otherwise stated.

The Clipper Formation has been sub-divided into four distinct members on the basis of lithological and electronic log responses. The four members recognised (from oldest to youngest) are: the Lower Sandstone member, Upper Sandstone member, Interbedded member, and the Coal Measures member. 
Chapter 2. Geological Setting of the Great South and Canterbury basins

The top of the Lower Sandstone member is defined by a reduction in gamma ray log response, which has been interpreted to correspond to the development of sandstone interbeds (5-20 cm thick) with a less well developed argillaceous matrix. Sandstones in this member are quartzose, sublithic, poorly sorted, and coarse to very coarse grained (Hawkes and Mound, 1984; Simpson, 1993). There are also interbedded mudstones present within this member; these mudstones are micaceous and carbonaceous.

The overlying Upper Sandstone member is defined by increases in the number of sandstone interbeds and greater variability in thickness of individual sandstone units (ranging from 1-10 m thick). Sandstones from this member are quartzose, fine to coarse grained, rounded to sub-angular, non-calcareous, and occasionally carbonaceous. A silica matrix is more commonly developed than the argillaceous matrix of the underlying Lower Sandstone member.

The Interbedded member is characterised by the presence of discrete sandstone interbeds (ranging in thickness from 1-5 m), within a mudstone dominated succession. The top of this member is marked by the last occurrence (first occurrence downhole) of sandstone within the Clipper Formation. Sandstones within this member are quartzose, very fine grained, micaceous and carbonaceous with an argillaceous matrix. Interbedded mudstones and siltstones are light to dark grey and highly carbonaceous.

The uppermost member of the Clipper Formation is the Coal Measures member. This member is dominated by light grey to medium brown, carbonaceous and non-calcareous mudstones and siltstones. Coals present are black and vitreous.

Simpson (1993) has stated that paleoenvironments of deposition of the Clipper Formation range from alluvial fan at the base of the formation to fluvio-deltaic near the top, with a paralic influence suggested by marine dinoflagellates within the Interbedded unit.

Unconfomibly overlying the Clipper Formation is the Katiki Formation, which has been assigned to the Mata Series of the Upper Cretaceous [Piripauan (Mp) to Haumurian (Mh)] (Hawkes and Mound, 1984).

The top of the Haumurian Stage is not characterised by a distinctive change in lithology, rather it is defined by a slight increase in carbonate content. Below this, sediments developed occasional white argillaceous limestone interbeds and are age equivalent to the Herbert Formation, which was deposited in the southwest of the Canterbury Basin (Hawkes and Mound, 1984). 
Chapter 2. Geological Setting of the Great South and Canterbury basins

Basal sediments of the Katiki Formation were deposited in a generally shallow marine environment (shelf to upper bathyal), deepening to bathyal in the central basin (around Clipper-1) (Simpson, 1993; Field and Browne, 1989). Towards the northeast (around Resolution-1) the Katiki Formation is represented by the Conway Formation (Field and Browne, 1989). To the southwest (around Endeavour-1), the Pukeiwitahi Formation (which was deposited within the Katiki Formation) was deposited in an extensive flood plain and coal swamp environment. The Pukeiwitahi Formation overlies the Zapata Limestone (a thin unit of argillaceous limestone that also lies within the Katiki Formation) (Wilding and Sweetman, 1971). The Pukeiwitahi Formation consists of quartz-rich, gritty coal measures (Simpson, 1993), carbonaceous siltstones and mudstones which are continuous with overlying Cretaceous sediments. White argillaceous limestone interbeds very occasionally occur throughout the succession (Hawkes and Mound, 1984).

The Herbert Formation overlies the Pukeiwitahi Formation, possibly disconformably (Wilding and Sweetman, 1971). The Herbert Formation is comprised of marine sandstones, and like the Pukeiwitahi Formation, is restricted to the southwest of the Canterbury Basin. The formation is conformably overlain by Katiki Formation (Simpson, 1993).

Overlying the Katiki Formation are sediments from the Dannevirke Series. Hawkes and Mound (1984) have stated that the series consists of a largely homogeneous succession of mudstones and siltstones with occasional sandstones. Wilding and Sweetman (1971) and Hawkes and Mound (1984) define the lowermost formation of this series to be the Otepopo Greensand Formation (Otepopo Formation), which has been inferred to have been deposited during the lower Teurian (Dt). Wilding and Sweetman (1971) describe the formation as being comprised of highly argillaceous, soft, glauconitic greensand and the basal contact as being sharp, possibly due to a disconformity.

The Moeraki Formation [Teurian (Dt) to Mangaorapan (Dm)] overlies the Otepopo Greensand Formation. Hawkes and Mound (1984) stipulate that the base of the Moeraki Formation is marked by a decrease in the glauconite content from the high proportion of greensand of the Otepopo Greensand Formation. The contact between the Moeraki and Otepopo formations is gradational and is taken where mudstone predominates over greensand (Wilding and Sweetman, 1971).

It is possible that the relationship between the Otepopo Greensand and Moeraki formations is connected to/or are correlatives of the Te Uri member (a highly glauconitic 
Chapter 2. Geological Setting of the Great South and Canterbury basins

greensand unit) and the Waipawa Formation (mudstone) in the East Coast Basin of New Zealand as reported by Rogers et al. (2001).

The Moeraki Formation is a glauconitic and slightly carbonaceous, medium to dark brown mudstone which contains thin lenses of limestone and sandstone (Simpson, 1993; Hawkes and Mound, 1984). Within the formation lies a thin layer of dark brown to black, highly carbonaceous mudstone which resembles the Waipawa Formation of the East Coast Basin, and the Tartan Formation of the Great South Basin. It is this section that is of greatest importance to this present study.

The Moeraki Formation appears top be thickest in the central basin (around Clipper-1) and progressively thins towards the south (around Endeavour-1, and Galleon-1). To the northeast of the basin (around Resolution-1) the Moeraki Formation grades into Charteris Bay Sandstone (Simpson, 1993).

Field and Browne (1989) state that microfaunas indicate the Moeraki Formation was deposited in an outer neritic to upper bathyal paleoenvironments around Clipper-1 and Galleon-1, a nearshore setting at Endeavour-1, and shallower marine further southwards, towards Takapu-1A.

The top of Paleocene sediments are marked by distinctive changes from mudstone to siltstone lithologies, and an increased argillaceous content (Hawkes and Mound, 1984).

The top of the Dannevirke Series [Waipawan (Dw) to Porangan (Dp)] is tentatively correlated to the Abbotsford Mudstone Formation by Hawkes and Mound (1984); however, Field and Brown (1989) consider the Moeraki and Abbotsford formations to be correlatives. Their description of this section states that it predominantly consists of light to medium grey carbonaceous and glauconitic mudstones and siltstones.

Overlying the Dannevirke Series are strata from the mid to Late Eocene Arnold Series. The Arnold Series has been divided into two units. The lower unit, of Bortonian age (Ab), is the Hampden Formation, and is locally referred to as the Ashley Mudstone in the north of the Canterbury Basin (around Resolution-1). It consists of medium grey to brown micaceous, predominantly calcareous mudstone (Wilding and Sweetman, 1971; Hawkes and Mound, 1984) which was deposited in an outer shelf to bathyal paleoenvironment (Simpson, 1993). The upper unit is Runangan (Ar) to Kaiatan (Ak) in age, and is age equivalent to the Mokihi Formation (Hawkes and Mound, 1984). The unit consists of light grey argillaceous limestones and calcareous mudstones which are glauconitic and carbonaceous (Hawkes and 
Chapter 2. Geological Setting of the Great South and Canterbury basins

Mound, 1984). Field and Brown (1989) suggest that the Mokihi Formation should be included within the Hampden Formation.

Strata from the earliest Oligocene to Early Miocene [Whaingaroan (Lwh) to Waitakian $(\mathrm{Lw})]$ of the Landon Series are dominated by the Amuri Limestone. Deposition of this formation began in the latest Eocene to earliest Oligocene (?Ar-Lwd) (Simpson, 1993). The Amuri Limestone is locally referred to as the Amberly Limestone in the north of the Canterbury Basin. The Amuri Limestone is typically a marl or wackestone and occurs below a widespread upper Whaingaroan unconformity (Field and Brown, 1989). The formation has a fine to very fine grained texture, suggesting an outer shelf or slope paleoenvironments of deposition (Field and Brown, 1989; Simpson, 1993).

The Otekaike Limestone [Duntroonian (Ld) to Waitakian $(\mathrm{Lw})]$ ranges from wackestone to grainstone in texture and has been interpreted by Field and Brown (1989) to have been deposited in an intra-shelf basin setting. Deposition of this formation continued in to the Early Miocene [Otaian (Po); the beginning of the Pareora Series] over most of the south of the Canterbury shelf basin. The Otekaike Limestone is overlain by the sandy basal sediments of the Tokama Siltstone, which consists of calcareous fine-sandy siltstones. Field and Brown (1989) state that this formation was deposited in a mid-neritic paleoenvironment and is a correlative of the Rifle Butts Formation identified towards the southwest section of the Canterbury Basin.

From Simpson (1993; Figure 2), Field and Browne (1989; Appendix 1-profile G), and Crown Minerals (2008c; Figure 1), it appears that the Tokama Siltstone (and its correlatives) is the dominant formation from the mid Miocene to Recent.

Dylan Meadows, 2009. 
Chapter 2. Geological Setting of the Great South and Canterbury basins

\subsubsection{Stratigraphy and Structure of Canterbury Basin Petroleum Exploration Wells}

\section{Sampled}

The generalised stratigraphy of the four wells from the Canterbury Basin investigated in the present study are presented in Figure 2.5.
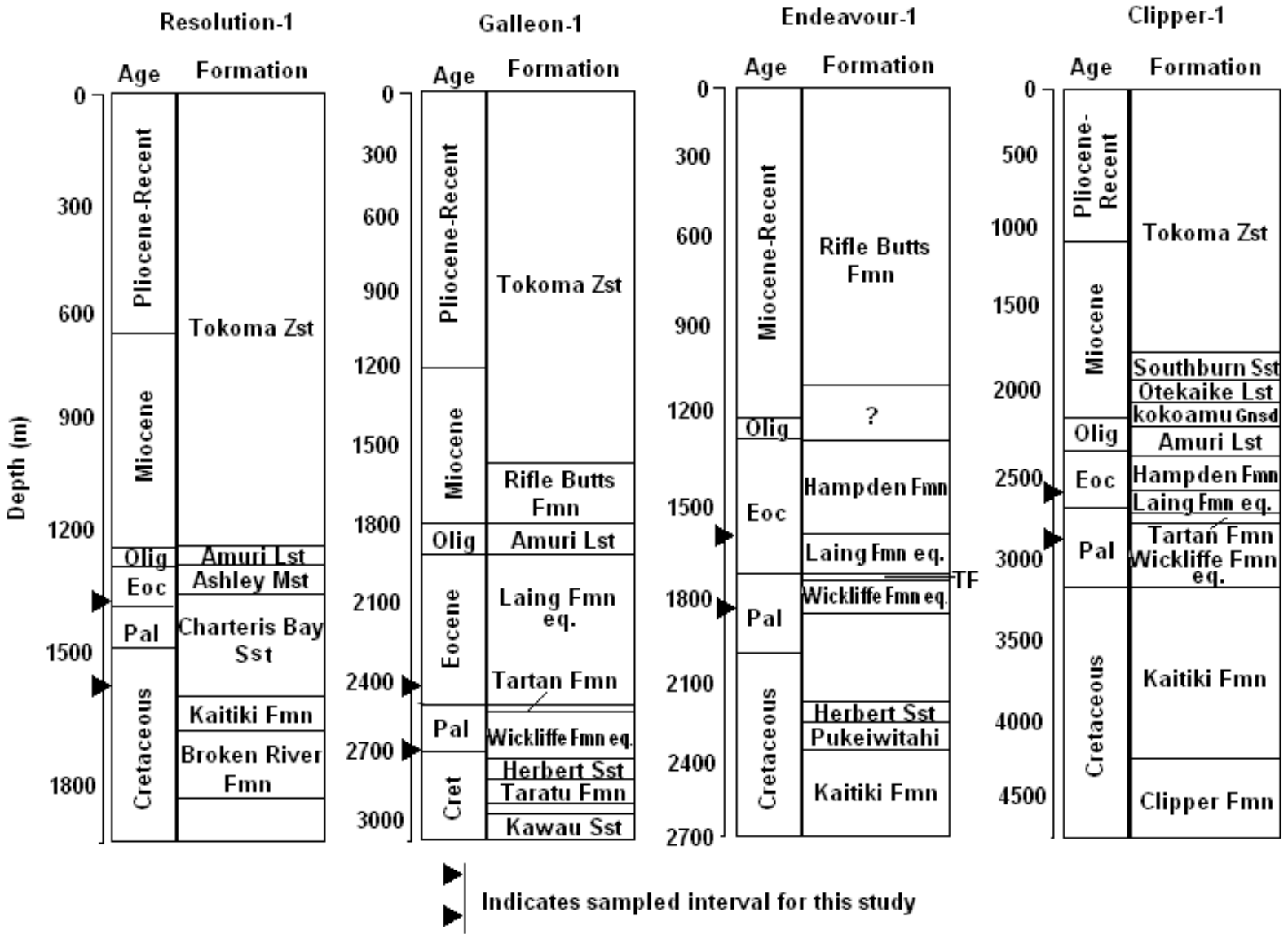

Figure 2.5 Generalised stratigraphy of Resolution-1, Galleon-1, Endeavour-1 and Clipper-1.

\section{Resolution-1}

The Resolution-1 petroleum exploration well is situated in the northeastern sector of the Canterbury Basin (Fig. 1.2) beneath $64 \mathrm{~m}$ of water. The Resolution structure comprises a NE-SW trending anticline that is thought to have developed as a result of igneous intrusions up-doming mid to Late Tertiary strata (Milne, 1975).

Dylan Meadows, 2009. 
Chapter 2. Geological Setting of the Great South and Canterbury basins

\section{Endeavour-1}

The Endeavour-1 petroleum exploration well is located in the southwestern sector of the Canterbury Basin (Fig. 1.2) below approximately $40 \mathrm{~m}$ of water. The well was drilled on a NE-SW trending anticlinal structure that was possibly raised as a result of early to mid Tertiary igneous intrusions (Wilding and Sweetman, 1971).

\section{Galleon-1}

The Galleon-1 petroleum exploration well situated in the southwestern sector of the Canterbury Basin (Fig. 1.2) under approximately $90 \mathrm{~m}$ of water. The Galleon structure is a four-way dip-closed, weakly faulted anticlinal drape feature that developed above a NE-SW trending basement high (Gibbons and Fry, 1986).

\section{Clipper-1}

The Clipper-1 petroleum exploration well is located in the centre of the Clipper Sub-basin, in the central-south area of the Canterbury Basin (Fig. 1.2) beneath approximately $150 \mathrm{~m}$ of water. The Clipper structure is an anticlinal drape feature over a basement rise. The structure has a closure area of approximately $50 \mathrm{~km}^{2}$ and $275 \mathrm{~m}$ of vertical closure (Hawkes and Mound, 1984).

\subsection{The East Coast Basin}

The stratigraphy of the East Coast Basin is included here because of the importance of correlation between the Tartan Formation of the Great South and Canterbury basins and the Waipawa Formation of the East Coast Basin. This correlation will be discussed in more detail later.

\subsubsection{Stratigraphy of the East Coast Basin}

The Whangai Formation is a siliceous mudstone ranging from Late Piripauan/Haumurian (Late Cretaceous) to Early Teurian (Paleocene) in age. The formation is widely distributed through the eastern North Island, and is also present in other parts of New Zealand. 
Chapter 2. Geological Setting of the Great South and Canterbury basins

The formation is made up of five members: Rakauroa, Upper Calcareous, and Porangahau members, and two members with more local distribution, the Kirks Breccia and the Te Uri Member (Moore, 1988b) (Fig. 2.6). Whangai Formation in almost all exposures is conformably overlain by Waipawa Formation (Moore, 1989).

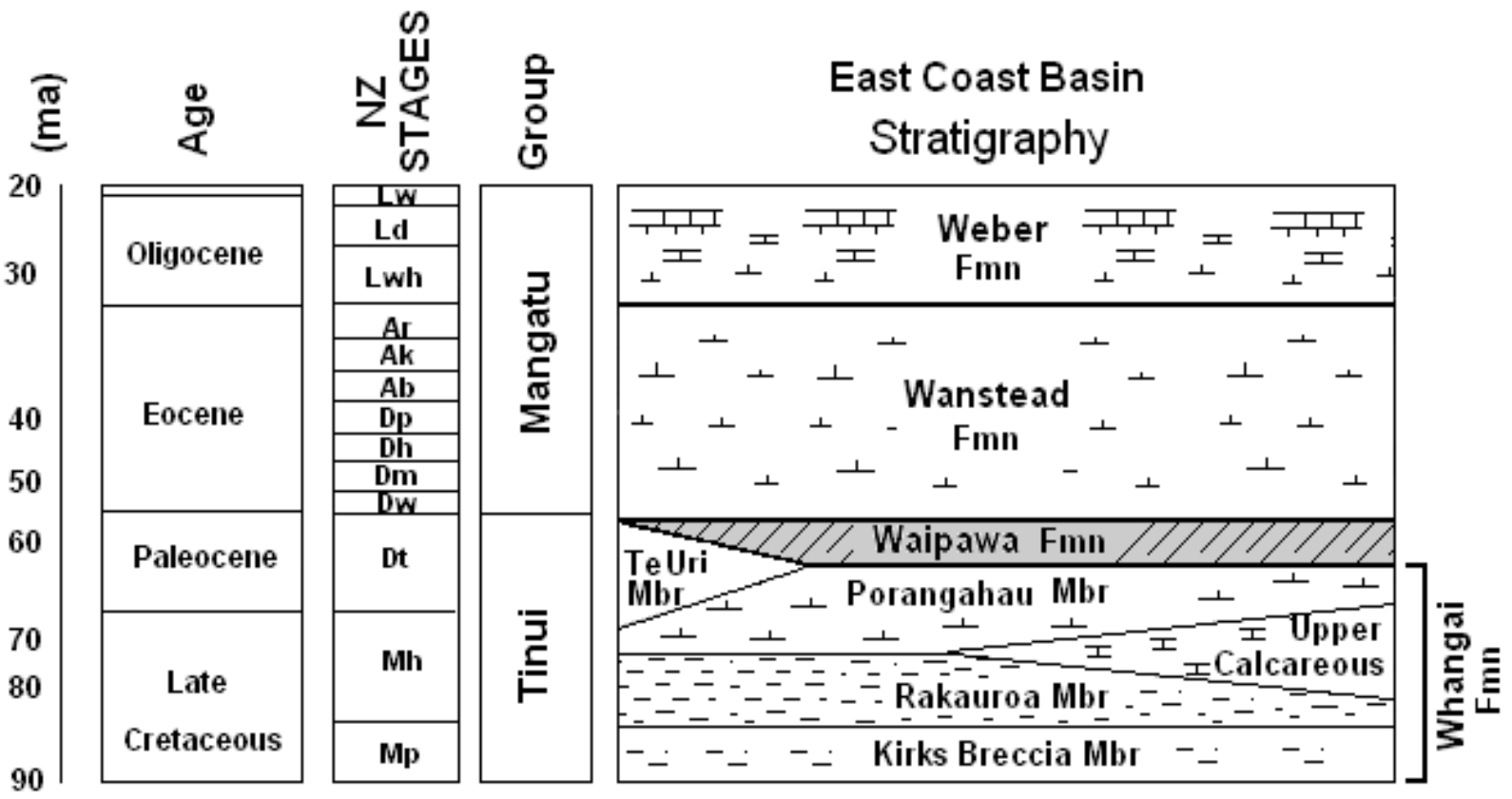

Figure 2.6 General stratigraphy of the East Coast Basin (Modified from Rogers et al. 2001).

The Late Piripauan (Mp)-Early Haumurian (Mh) Kirks Breccia is the lowermost member of the Whangai Formation. It contains poorly sorted, matrix to clast-supported breccia beds $30 \mathrm{~m}$ to $200 \mathrm{~m}$ thick. Clasts consist of fine sandstone, light and dark grey mudstone and concretions in a micaceous and gritty mudstone matrix (Moore, 1988b).

The next unit of the Whangai Formation is the Rakauroa Member. The member is primarily of Haumurian age, though some basal sediments may be Late Piripauan. The unit ranges from $40 \mathrm{~m}$ to $400 \mathrm{~m}$ in thickness but tends to average $200 \mathrm{~m}$ to $300 \mathrm{~m}$. The Rakauroa Member comprises hard, typically very poorly bedded, rusty weathering, bioturbated, medium grey, non-calcareous, micaceous mudstone that has also has thin glauconitic sandstone beds, and scattered pyrite nodules and calcareous concretions. Fine laminations are present near the base the member, consisting of alternating light grey and dark grey siltstone and mudstone. Some areas are more strongly laminated than others (Moore, 1988b).

Dylan Meadows, 2009. 
Chapter 2. Geological Setting of the Great South and Canterbury basins

The Upper Calcareous Member is of Haumurian to Early Teurian age. The unit ranges in thickness from $50 \mathrm{~m}$ to $200 \mathrm{~m}$ and is a hard, generally very poorly bedded, light bluish-grey weathering, medium grey, slightly to moderately calcareous, bioturbated, laminated micaceous mudstone. The unit contains sporadic concretions, pyrite nodules, glauconitic sandstone beds and rare breccias, and the carbonate content generally increases upward (Moore, 1988b).

Overlying the Upper Calcareous Member is the Early Teurian Porangahau Member, with a thickness of $20 \mathrm{~m}$ to $300 \mathrm{~m}$. The unit consists of mainly hard, well bedded, light grey, slightly to highly calcareous mudstone, which is usually moderately to highly bioturbated. Glauconitic sandstone beds are common (Moore, 1988b). The unit is commonly termed the "zebra facies", based on thin alternating light and darker grey mudstone layers through the Porangahau Member.

The Te Uri Member consists of approximately $35 \mathrm{~m}$ of interbedded glauconitic sandstone and hard, light grey, glauconitic, slightly calcareous, laminated siltstone, which disconformably overlies the Upper Calcareous Member. The Te Uri Member has a similar composition to the underlying Whangai mudstone, with the only major lithologic difference being the higher glauconite proportion of the Te Uri Member. The member is most likely Early Teurian in age. Moore (1988b) stated that the Te Uri Member appears to be a lateral equivalent, in part, of the Waipawa Formation.

Waipawa Formation conformably overlies the Whangai Formation and is widely distributed throughout the East Coast Basin. The formation is of mid-Late Teurian age and rarely exceeds a thickness of $50 \mathrm{~m}$. The Waipawa Formation consists primarily of very poorly bedded, hard to moderately soft, dark brown-grey to brownish black, non-calcareous micaceous siltstone. Locally, there is a high proportion of glauconitic sandstone, and also some intervals of Whangai-like calcareous mudstone. In some places the shale is highly bioturbated, but contains very few macrofossils other than small bivalves and rare gastropods (Moore, 1988b, 1989). Upper and lower contacts are relatively sharp, although the basal contact with the Whangai Formation is commonly gradational over a few centimeters to several meters.

Waipawa Formation overlies different facies of the Whangai Formation across the East Coast region. Moore $(1988 b, 1989)$ stated that this was due to the base of the Waipawa Formation probably being diachronous based on his observation that the Waipawa 
Chapter 2. Geological Setting of the Great South and Canterbury basins

Formation overlies different members of the upper Whangai formation in different locations; however, Rogers et al. (2001) observed this as evidence for the upper members of the Whangai Formation to be diachronous, and facies dependent, rather than the Waipawa Formation.

Waipawa Formation is conformably overlain by Wanstead Formation, which is of Teurian (Dt) to Runangan age (Ar) (Late Paleocene-Eocene). The formation consists of poorly bedded, moderately hard, light grey to greenish-grey weathering, micaceous, slightly calcareous mudstone. The mudstone is intensively bioturbated and contains isolated glauconitic sandstone beds. The Wanstead Formation has a maximum thickness of $490 \mathrm{~m}$ (Leckie et al. 1992) but is poorly exposed, and thus accurate thickness determinations are difficult.

Wanstead Formation is conformably overlain by Weber Formation. This consists of up to $370 \mathrm{~m}$ of primarily fine-grained, hard, light-grey, bioturbated, calcareous mudstone with minor interbeds of glauconitic sandstone. Ages range from Whaingaroan (Lwh) (Early Oligocene) to likely Duntroonian (Ld)/Waitakian (Lw) (Late Oligocene-Early Miocene) (Leckie et al. 1992). 
Chapter 3. The Tartan Formation

\section{CHAPTER 3}

\section{The Tartan Formation}

\subsection{Nomenclature and distribution of the Tartan Formation (and equivalents)}

\section{Nomenclature}

The name Waipawa Black Shale was first introduced by Finlay (1940) in a discussion of the distribution of Conotrochammina whangaia (Moore, 1989); however, it was Hornibrook and Harrington (1957) who made the first adequate description of the shale. It was formally defined in by Hornibrook (1959) who also termed the unit the 'Waipawa Black Siltstone'. Moore $(1987,1988 b, 1989)$ referred to the unit as both the Waipawa Black Shale and the Waipawa Formation; the latter being more commonly used since by authors referring to the formation in the East Coast Basin and elsewhere around New Zealand (see Field and Uruski, 1997; Killops et al. 1996; Killops et al. 2000; Rogers et al. 2001; Hollis et al. 2005; Hollis et al. 2006). Killops et al. (1997) use the term 'Tartan Member' to refer to the Late Paleocene Waipawa Black Shale equivalent in the Great South Basin. Cook et al. (1999) raised this unit to formation status and 'Tartan Formation' is now generally accepted as the formal name for the formation in the Great South Basin. Cook et al. (1999) stated that the Tartan Formation closely resembles the Waipawa Formation of eastern North Island, but used the name Tartan Formation because of the wide geographical separation between the Great South and East Coast basins.

In keeping with Cook et al. (1999), the present author also refers to the Late Paleocene black shale of southern New Zealand as the Tartan Formation. Reports by Killops et al. $(1997,2000)$ referred to this section as the Waipawa Formation in the Canterbury and Great South basins. Baillie and Uruski (2004) considers the southern limit of the Canterbury Basin to be contiguous with the northern area of the Great South Basin (Section 2.1.3). I regard the proximity of the Great South and Canterbury basins, the stratigraphic position of the shale over these basins (see Chapter 2), and the data obtained from the study by Meadows (2008) (see Appendix 3 for table of results) and the present study (see Chapter 6; Results, and Appendix 4) as valid reasons to extend the term 'Tartan Formation' to the Canterbury Basin. 
Chapter 3. The Tartan Formation

\section{Distribution}

The Tartan Formation and its stratigraphic equivalent, the Waipawa Formation, have been identified in several sedimentary basins around New Zealand. These are the Great South Basin, (Raine et al. 1993; Killops et al. 1997), the Canterbury Basin (Gibbons and Fry, 1986; Field and Browne, 1989; Killops et al. 1997), the East Coast Basin, from the Te Hoe River and East Cape in the northern region of the East Coast Basin to the Hawkes Bay-Wairarapa in the southern region of the East Coast Basin (Moore, 1988b, 1989; Field et al. 1997), Northland (Isaac et al. 1994; Hollis et al. 2005), northern Taranaki (Killops et al. 1994; King and Thrasher, 1996) and Marlborough (Strong et al. 1995). The formation is possibly also present in southern Westland (Nathan, 1976) (Fig. 3.1).

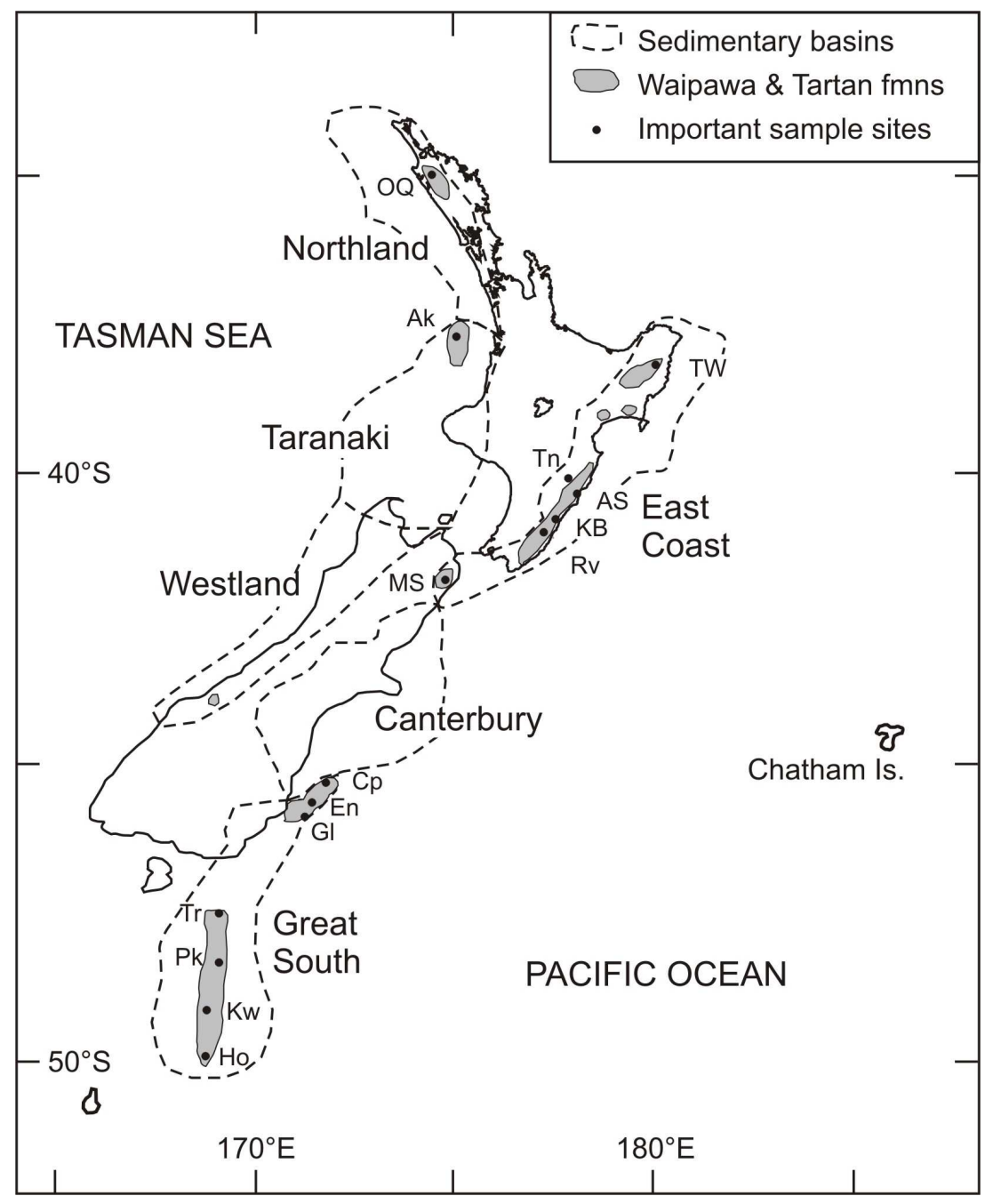

Figure 3.1 Regional distribution of the Tartan and Waipawa formations around New Zealand's sedimentary basins (Redrawn from From Killops et al. 1996, 2000). 
Chapter 3. The Tartan Formation

Outcrops of Waipawa Formation in the East Coast Basin show the contact with the underlying Whangai Formation to be conformable and typically gradational over centimeters to meters, and that with the overlying Wanstead Formation to be sharp but conformable, as reported by Moore (1986a, 1988b, and 1989) and Killops et al. (2000). Correlatives of the Wanstead and Whangai formations are recognised in exploration wells in the Great South Basin in which Tartan Formation is present; and in the Canterbury Basin, where a Tartan Formation equivalent has also been identified. As in the East Coast Basin, there are gradual changes in sedimentological characteristics at the Whangai/Waipawa boundary (Killops et al. 2000), which is equivalent to the Wickliffe/Tartan boundary in the Great South Basin. Whangai Formation equivalents occur in the Northland Basin, with a conformable, gradational boundary with the overlying Waipawa Formation (Isaac et al. 1994), and a Waipawa Formation equivalent formation appears to be present in the Ariki-1 exploration well in the Taranaki Basin. In both Northland and Taranaki basins, the Waipawa Formation is overlain by deep-water facies that resemble the Wanstead Formation (Killops et al. 2000).

\subsection{Thickness and depositional environment of the Waipawa and Tartan formations}

The Tartan Formation has been identified in five exploration wells in the Great South Basin: Toroa-1 (57 m thick), Pakaha-1 (41 m thick), Hoiho-1C (39 m thick), Kawau-1A (44 $\mathrm{m}$ thick), and is also represented in Pukaki-1 (30 m thick) (Schioler and Roncaglia, 2008). In comparison, Tartan Formation and equivalents encountered in exploration wells in other basins are generally thinner, such as in the Canterbury Basin (Clipper-1, $35 \mathrm{~m}$ thick; Endeavour-1, $40 \mathrm{~m}$ thick; and Galleon-1, $10 \mathrm{~m}$ thick) and in the Taranaki Basin, where only one exploration well has a Tartan Formation equivalent (Ariki-1, $10 \mathrm{~m}$ thick) (Fig. 3.1) (Killops et al. 2000). Moore (1988b, 1989) stated that the Waipawa Formation in East Coast Basin outcrops rarely exceeds a thickness of $50 \mathrm{~m}$.

During deposition of the Waipawa Formation, ocean surface waters were warmer than immediately prior to deposition of the formation (see Chapter 4). The global dysaerobic event that occurred during the latest Paleocene at the Teurian-Waipawan boundary, $55.5 \mathrm{Ma}$ is defined by extinctions and by carbon and oxygen isotopic excursions in benthic foraminiferan tests at high latitudes in the Southern Hemisphere oceans (Kennett and Stott, 1991; Zachos et al. 1993; Thomas, 1990).

Dylan Meadows, 2009. 
Chapter 3. The Tartan Formation

It is possible that the characteristic high organic content of the Waipawa Formation is the result of changes in oceanic circulation patterns prior to the benthic extinctions of the Late Paleocene warming (Field et al. 1997) (see Chapter 4).

The Waipawa Formation is interpreted to represent a condensed section that was likely to have been deposited at the peak of marine transgression or highstand of sea-level following a major lowering of the Late Paleocene sea-level (Haq et al. 1987; Strong et al. 1995; Rogers et al. 2001) during a period of global warming that began in the mid-Paleocene and climaxed during Late Paleocene to Early Eocene time (Zachos et al. 1993). Schioler and Roncaglia (2008) have reported that the Tartan Formation was deposited during a maximum regression in the Thanetian (Late Paleocene) (see Section 3.5).

Paleogeographic reconstructions (Fig. 3.2) show areas where the Waipawa Formation (and Tartan Formation) was deposited widely over the New Zealand landmass (Field et al. 1997).

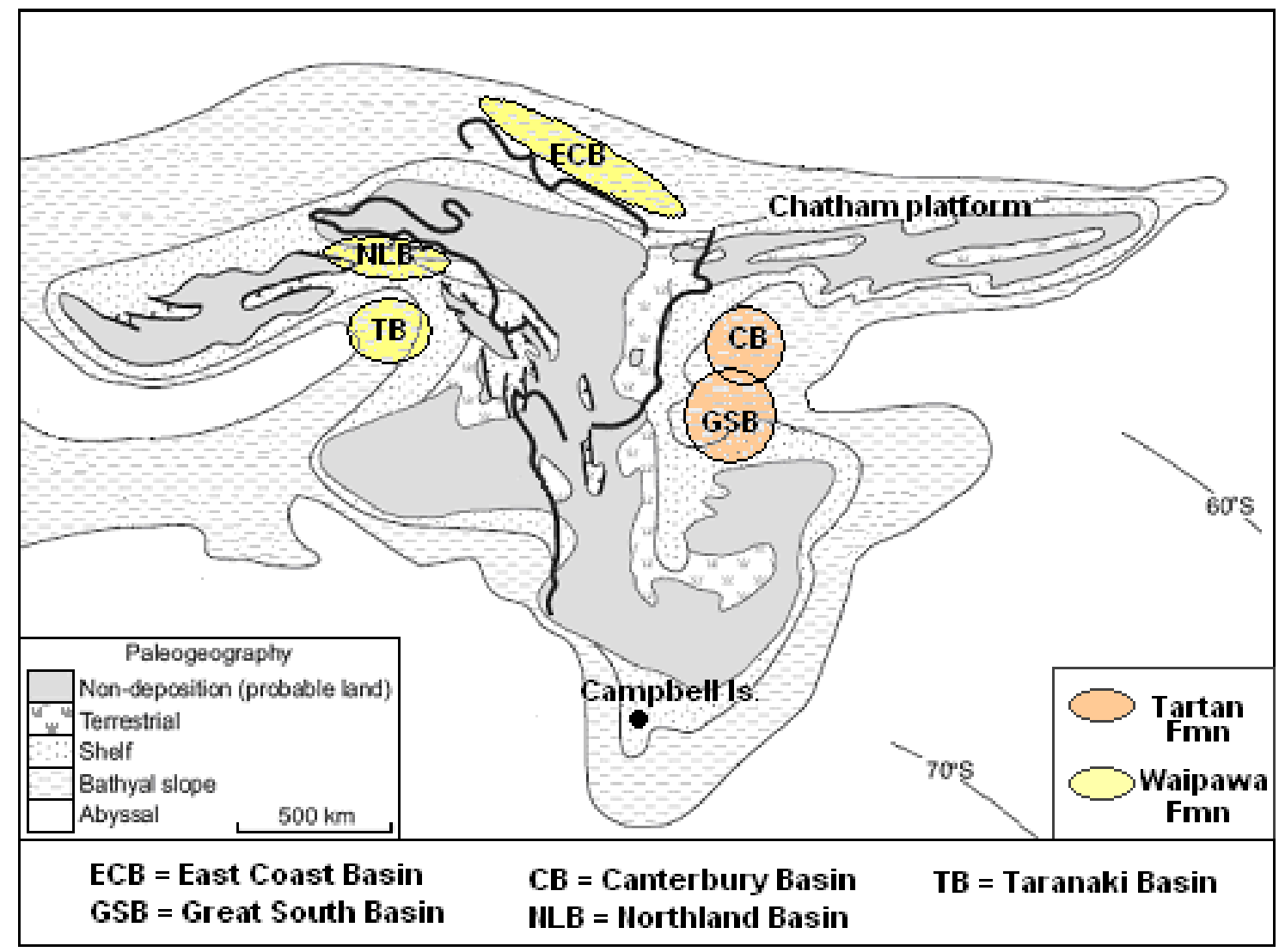

Figure 3.2 Paleogeographic reconstruction of the New Zealand microcontinent during the Late Cretaceous displaying basins where the Waipawa and Tartan formations have been identified. Modified from Hollis (2003). 
Dysaerobia has been associated with the deposition of the Waipawa Formation by Killops et al. (2000). This dysaerobia may have been instigated by high biological oxygen demand in the water column due to biological scavenging and reworking of descending organic matter. The biochemical degradation of this organic matter would have resulted in reduced oxygen saturation levels within the water. Killops et al. (2000) stated an important point, in that the change in circulation pattern from a thermohaline to halothermal system would create an oxygen-depleted water body below a depth of $200 \mathrm{~m}$, which may have also contributed to or had a profound influence on dysaerobic conditions during the deposition of the Waipawa Formation.

From the wide distribution of the Waipawa Formation and its equivalents throughout New Zealand it is unlikely that it was deposited contemporaneously in a number of basins with restricted bottom water circulation (Field et al. 1997). Wind-driven upwelling may have had a partial influence on high organic content of the Waipawa Formation in some places, but was unlikely to have been the cause of distinctive features of the formation such as the high sterane content and its paleodistribution around much of the New Zealand landmass (Killops et al. 1996; Killops et al. 2000; Field et al. 1997). It is probable that the degradation of a significant amount of organic matter below an area of high phytoplankton productivity, resulting from upwelling, led to sediments rich in organic content being deposited over a large part of the New Zealand region (Field et al. 1997).

To produce almost entirely anoxic bottom waters in an open, well-oxygenated marine setting from the aerobic decomposition of organic matter would require exceptionally high productivity in the surface waters, and this unusually high productivity would have had to have taken place over a large area to account for the distribution of the Waipawa Formation. Field et al. (1997) pointed out that there is no clear evidence that the Waipawa Formation is associated with such extreme high productivity, although the authors concluded that the high organic content of the formation did suggest that high productivity was involved. In some places, biogenic reworking and degradation prevented the preservation of organic carbon in equivalent condensed stratigraphic intervals, such as in the East Coat Basin. A likely example of this is documented by Rogers et al. (2001) for Tawanui. Here, the presence of greensands of the Te Uri Member rather than the coeval black shale of the Waipawa Formation observed in the nearby Angora Stream, approximately $10 \mathrm{~km}$ away, suggest that 
Chapter 3. The Tartan Formation

conditions were oxygenated enough for biologic degradation of organic matter deposited in the Tawanui area but not oxygenated enough for degradation of organic matter at Angora Stream.

Abundant sulfur and its large range of isotopic fractionation, shown by negative $\delta^{34} \mathrm{~S}$ values for kerogen and bitumen samples, suggest sulfate reduction with an unrestricted supply of fresh sulfate, which is typical of anoxia in an open marine system was likely to have taken place during the deposition of the Waipawa Formation (Killops et al. 2000).

Killops et al. (2000) have stated that 28, 30-Dinorhopane has a very high abundance in some Waipawa Formation samples from wells in the Great South Basin, such as Pakaha-1 and Kawau-1A. Waples and Machihara (1991) mention that sediments containing large amounts of 28, 30-Dinorhopane are often indicative of deposition under anoxic conditions. The high abundance of 28,30-Dinorhopane is suggested to be evidence of anoxic conditions developing rapidly within the sediments (Cook et al. 1999; Grantham et al. 1980). Killops et al. (2000) concurred, stating that anaerobia must have developed rapidly within the sediments based on the sulfur isotopic composition and content, benthic faunal abundances, and gamma ray logs of samples analysed from the Waipawa Formation.

The Waipawa Formation has an unusually high abundance of 24-n-propylcholestanes, which is diagnostic of a marine algal or phytoplankton contribution (Killops et al. 2000). Killops et al. (2000) stated that surface water conditions must have favoured phytoplankton that preferentially synthesised the $\mathrm{C}_{30}$ sterol precursors. Deposition of the Waipawa Formation coincides with a sharp increase in the abundance of 24-n-propylcholestanes; however, the relative abundance of 24-n-propylcholestanes began increasing gradually prior to the deposition of the Waipawa Formation earlier in the Teurian, during the deposition of the Upper Calcareous Member (UCM) of the Whangai Formation (Killops et al. 2000).

Deposition of the Waipawa Formation under dysaerobia is marked by very limited bioturbation in most exposures and low abundances of benthic microfossils (Killops et al. 2000). It is likely that the water immediately above the sediment/water interface was not completely anoxic, as shown by the presence of bioturbation within the Waipawa Formation.

The Waipawa Formation has very poor preservation of foraminifera; however, there is some evidence for changes in the foraminiferal assemblages through time. Below the Waipawa Formation sediments are dominated by benthic species, while the formation above the Waipawa Formation primarily contains planktonic species. Within the Waipawa 
Chapter 3. The Tartan Formation

Formation faunas are poor but most are planktonic species together with some calcareous and agglutinated benthics (Strong et al. 1995).

Strong et al. (1995) proposed that the Haplophragmoides-dominated assemblages that are commonly recovered may indicate environmental stress that could have resulted from low oxygen/high organic matter deposition. The "elongate nodosariids" are indicative of dysaerobia (Kaiho, 1991) and the presence of Alabamina is considered to be an indicator of deposition under a sub-oxic environment (Kaiho, 1994).

Strong et al. (1995) stated that there is no evidence for a major depth change at the time of deposition, suggesting that the Waipawa Formation was deposited under bathyal conditions. Killops et al. (2000) reached a similar conclusion and suggested that an open marine depositional environment, beyond the neritic zone, was associated with the deposition of the underlying Whangai and the overlying Wanstead formations. Waipawa Formation deposition corresponds to inner shelf or basal slope/abyssal environments (Killops et al. 1996; Killops et al. 2000). Field et al. (1997) and Cook et al. (1999) also concluded that in places that the Waipawa Formation was deposited, the formation was deposited in fairly deep water, below the limit of wave action $(>200 \mathrm{~m})$ and possibly on the upper continental slope, whereas deposition in the Great South Basin appears to have taken place in a relatively shallow, restricted marine environment (Raine et al. 1993).

The upwelling event that is associated with the deposition of the Waipawa Formation would have provided nutrients to the surface waters around the shelf break and could have caused shoaling of the oxygen minimum layer so that it impinged on the upper continental slope (Killops et al. 1996; Killops et al. 2000). The high primary productivity that accompanied the deposition of the Waipawa Formation could have occurred during a period of high sea-level that followed a glacio-eustatic fall. This period of glacio-eustatic fall during the mid Paleocene is marked by dropstones in the Upper Calcareous Member of the upper Whangai Formation that underlies the Waipawa Formation (Leckie et al. 1995).

At some locations where the Waipawa Formation is present, it is represented by two organic-rich black mudstone units separated by a less organic-rich and more calcareous unit (Killops et al. 1996, Hollis et al. 2005). The organic-rich layers may correspond to more intense episodes of upwelling (Field et al. 1997). Degradation of large amounts of organic detritus sinking through the water column would have intensified dysaerobia, enhancing preservation of the organic matter in the formation. 
Chapter 3. The Tartan Formation

The differences between the Tartan Formation of the Great South and Canterbury basins and the Waipawa Formation present elsewhere in New Zealand are likely related to the deposition of the Tartan Formation in relatively shallow water behind a near-surface ridge that was present from the Late Cretaceous to the Paleocene. This ridge was present immediately to the west of and extended parallel to the line of wells in the Great South Basin from which the Tartan Formation has been identified (Killops et al. 1996; Killops et al. 2000; Cook et al. 1999). The conditions associated with the deposition of the Waipawa Formation were present in the Great South and Canterbury basins; however, differences between the Tartan and Waipawa formations are likely due to local variations during deposition (Hollis et al. 2005).

\subsection{Lithology and recognition of the Tartan Formation}

Cook et al. (1999) described the Tartan Formation as a dark brown, firm, carbonaceous, slightly calcareous, very micaceous, and slightly glauconitic shale. Sidewall core and cuttings samples also exhibit clear visual changes in lithology, from the light grey shales and clays of the underlying Wickliffe Formation to the dark brown shales of the Tartan Formation, which is in turn overlain by siltstones and calcareous clays of the Laing Formation.

The Tartan Formation characteristically produces a higher than normal gamma ray response (Cook et al. 1999), which is very distinctive when compared to the responses produced by surrounding formations (see Figure 7.1).

\subsection{Tartan geochemical facies}

Reports by Cook et al. (1999) and Schioler, (pers. comm. 2008) define the Tartan Formation by its lithology and is recognised by its gamma ray log response. The suite of geochemical analyses performed in Meadows (2008) agree with the gamma ray data in defining the top of the Tartan Formation; however, the geochemical data (both TOC and $\delta^{13} \mathrm{C}$ ) from some wells demonstrate changes that appear below the recognised base of that formation (particularly in Kawau-1A and Pakaha-1), in the top of underlying Wickliffe Formation. For this reason, a geochemical facies termed the Tartan geochemical facies (TGF) was used to describe this interval by Meadows (2008).

In light of new data and further correlation the author has decided to discontinue using this name for the interval. The apparent differences between the gamma ray logs and 
Chapter 3. The Tartan Formation

geochemical data have now been inferred as having been the result of local conditions' response to the Paleocene Carbon Isotope Maximum (PCIM). The relationship between the Tartan Formation is further discussed in Section 3.5 and in Chapter 7.

\subsection{Age of the Tartan Formation (and equivalents)}

The age of the Tartan Formation has been reported in several publications, most citing deposition during the Late Paleocene; however, few have provided a specific age for the formation.

Cook et al. (1999) stated that the Tartan Formation was deposited during the Late Teurian (Late Paleocene), and from the gamma ray depths provided in that publication, and that by Schioler and Roncaglia (2008), correlation to the biostratigraphic review of the Great South Basin has been made by Raine et al. (1993) (see above biostratigraphic summaries of Great South and Canterbury basin wells). From their work, it is accepted here that the Tartan Formation was deposited between the mid Teurian (Dt) to earliest Waipawan (Dw) Stages.

Schioler and Roncaglia (2008) reported that the Tartan Formation was deposited during a peak regression during the Thanetian (58.7 to $55.8 \mathrm{Ma}$ ) Stage of the Late Paleocene, which approximately correlates to the duration of the Paleocene Carbon Isotopic Maximum (PCIM) 59.5 to $55.5 \mathrm{Ma}$ presented in Zachos et al. (2001; Figure 2) (Chapter 4). Tartan Formation deposition took place between a regressive trend in the Paleocene Wickliffe Formation and a Late Paleocene to Early Eocene transgression in the Laing Formation.

Killops et al. (2000) stated that the Waipawa Formation (in the Great South Basin and elsewhere around New Zealand) was deposited within a third-order eustatic rise in sea level (Haq et al. 1987), preceded by a climatic cooling at $59.1 \mathrm{Ma}$ (as described by Leckie et al. 1995), and a thermal maximum at 55.5 Ma, which Killops et al. (2000) mentioned is coincident with the Teurian-Waipawan (Paleocene-Eocene) boundary above the top of the formation. Killops et al. (2000) state that the top of the Waipawa Formation may be older than 55.5 Ma. They reported that there is commonly an undated stratigraphic gap between the top of the Waipawa Formation and the Teurian-Waipawan boundary due both to a scarcity of dateable microfossils and to sampling gaps within this section (which had previously been noted by Moore (1989) in East Coast Basin outcrops. At the Angora Stream outcrop (East Coast Basin), approximately $15 \mathrm{~m}$ of strata from the Teurian Wanstead Formation (see section 2.3) overlie Waipawa Formation. Similarly, in Kawau-1A (Great 
Chapter 3. The Tartan Formation

South Basin) the top of the Teurian lies approximately $80 \mathrm{~m}$ above the top of the Waipawa (Tartan) Formation, and in Galleon-1 (Canterbury Basin) there appear to be between $60 \mathrm{~m}$ and $100 \mathrm{~m}$ of Teurian deposits overlying Waipawa (Tartan) Formation (Killops et al. 2000). Killops et al. (2000) attempted to further constrain the age of the Tartan Formation by inferring constant depositional rates throughout the Teurian (based on rates estimated for Kawau-1A, Pakaha-1, and Toroa-1), and concluded that the formation was deposited over roughly 1.5 Myr between approximately 57.5 and $56 \mathrm{Ma}$.

Hollis et al. (2005) correlated Late Paleocene organic rich mudstones outcropping at Mead Stream outcrop (inland Marlborough) to the Waipawa Formation. The Waipawa Formation equivalent mudstone is suggested to represent the lower interval of the PCIM at Mead Stream (Hollis et al. 2005). Biostratigraphic constraints placed on the Waipawa Formation equivalent at Mead Stream and Tawanui (East Coast Basin) by Hollis et al. (2000) and Rogers et al. (2001) restricted the depositional age to between 58-57 Ma (Hollis et al. 2005).

The correlation between Tartan Formation deposition and the global Paleocene Carbon Isotope Maximum is further discussed in Chapter 7.

The biostratigraphy of the individual wells examined in this study and that by Meadows (2008) are discussed in Appendix 2. 


\section{CHAPTER 4}

\section{Environmental conditions during the Late Paleocene and Early Eocene}

\subsection{Early Paleogene temperature fluctuations}

Records from the Ocean Drilling Project (ODP) around the Southern Ocean indicate that a period of rapid climate change culminated in a brief transient climate of exceptional warmth during the Late Paleocene. This transient climate, referred to as the Late Paleocene Thermal Maximum (LPTM) (based on $\delta^{18} \mathrm{O}$ and temperature records), was a time of global warming that began to develop during the mid-Paleocene. The LPTM climate extreme was not stable and lasted only a few $100 \mathrm{kyr}$.

The time of the Paleocene-Eocene boundary was one of global transgression and was also the warmest period of the Cenozoic, with temperatures climaxing at the boundary (Field et al. 1997). Paleontologic proxies indicate that high latitude marine and terrestrial environments experienced near sub-tropical conditions (Zachos et al. 1993).

During the Early Paleogene, significant Antarctic warmth and higher precipitation may have caused a large reduction in deep waters derived from the high latitudes and polar sources. The highest temperature of the deep oceanic water was around $11-15{ }^{\circ} \mathrm{C}$ during the Early Eocene (Kennett and Stott, 1991).

Preceding the Late Paleocene to Early Eocene warming was a period of cooling, which is marked by a decline in deep sea water temperatures derived from $\delta^{18} \mathrm{O}$ benthic records from 65 to $62 \mathrm{Ma}$ (Corfield and Cartlidge, 1992). This period also recorded a significant carbon isotope excursion (CIE) (Figure 4.1), which Corfield and Cartlidge (1992) referred to as the Paleocene Carbon Isotope Maximum (PCIM) (based on $\delta^{13} \mathrm{C}$ records). They stated that the event was brought on by both internal carbon isotope fractionation effects (such as fractionation within the oceanic reservoir of total dissolved carbon) and external carbon isotope fractionation effects (such as exchange between carbon reservoirs). Haq et al. (1987) presented a figure that depicts the eustatic curve through the Cenozoic, where the interval coinciding with the PCIM recording a drastic lowering of sea level, indicating a period of regression. 
Chapter 4. Environmental conditions during the Late Paleocene-Early Eocene

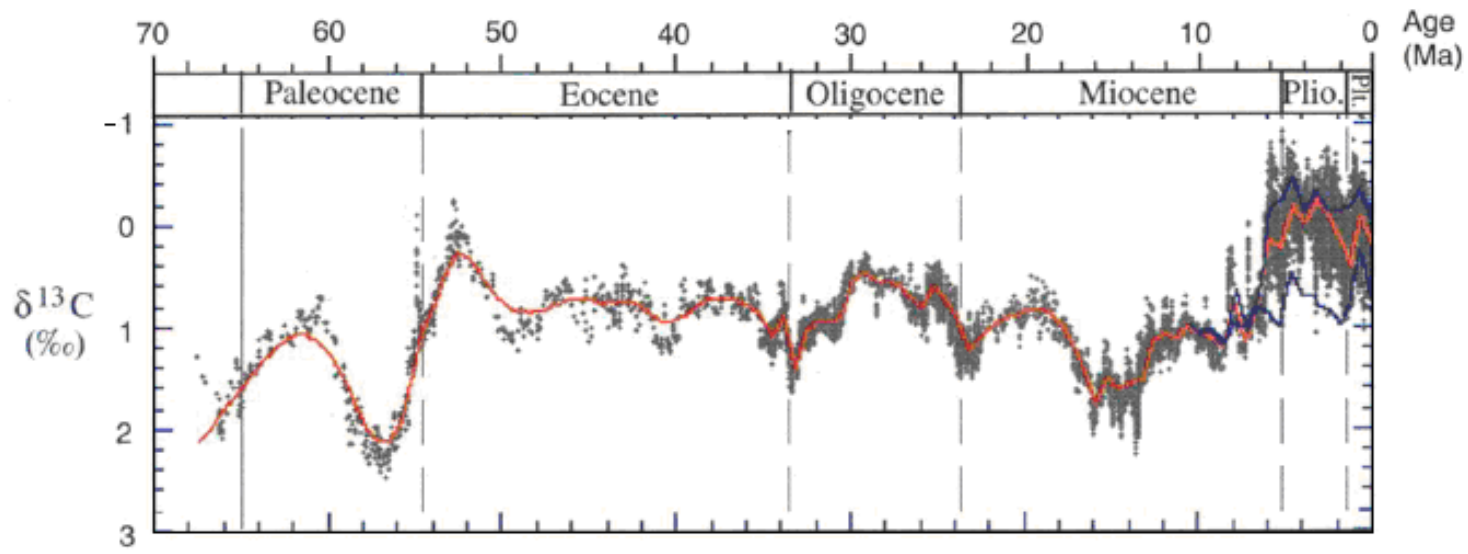

Figure $4.1 \delta^{13} \mathrm{C}$ record through the Cenozoic (from Zachos et al. 2001; Fig. 2). Typically, negative $\delta^{13} \mathrm{C}$ values correspond to cooler periods, whereas positive $\delta^{13} \mathrm{C}$ excursions correspond to warmer periods.

Kurtz et al. (2003) stated that the PCIM began 2 Myr after the Cretaceous-Tertiary boundary and peaked during the mid-Paleocene, then declined through the Late Paleocene into the Early Eocene.

Zachos et al. (1993) stated that, during the latest Paleocene, deep waters warmed to temperatures close to those at the ocean surface. This deep ocean warming temporarily eliminated the vertical temperature gradient between deep and surface waters, and carbonate records show decreases in both $\delta^{18} \mathrm{O}$ and $\delta^{13} \mathrm{C}$. The oceanic temperature gradient was reestablished $30 \mathrm{kyr}$ after the initial isotopic excursion.

The LPTM transient climate was accompanied by a re-organisation in ocean circulation and was marked by reduced oceanic turnover, and decreases in both marine productivity and global $\delta^{13} \mathrm{C}$. Benthic foraminiferal oxygen isotopic records show that, from the Late Paleocene to Early Eocene, deep sea temperatures warmed from $8{ }^{\circ} \mathrm{C}$ to $12{ }^{\circ} \mathrm{C}$. During this time, surface water temperatures increased by $5-6{ }^{\circ} \mathrm{C}$, with maximum temperatures exceeding $20^{\circ} \mathrm{C}$ (Zachos et al. 1993). This warming transition appears to have taken place in less than $10 \mathrm{kyr}$ and did not persist. Following this period of extraordinary warmth, temperatures almost immediately began to decrease, gradually cooling over the next $100 \mathrm{kyr}$ but remaining $1-2{ }^{\circ} \mathrm{C}$ higher then before the beginning of the excursion (Zachos et al. 1993; Kennett and Stott, 1991). 
Chapter 4. Environmental conditions during the Late Paleocene-Early Eocene

\subsection{Paleoceanographic conditions from the Paleocene to Eocene}

Based on $\delta^{13} \mathrm{C}$ studies by Corfield and Cartlidge (1992) concluded that during the Early Paleocene and part of the Late Paleocene (66 and $60 \mathrm{Ma}$ ), deep water production was more likely to have occurred at higher latitudes than low to mid latitudes. The decline in basinal $\delta^{13} \mathrm{C}$ gradients between the Atlantic and Pacific oceans from 60 to 56.2 Ma possibly indicates a change in the deeper regime. Corfield and Cartlidge (1992) have mentioned that more than one deep water source was active or that a low latitude source become more predominant or a high latitude source became less dominant during the interval 60 to $56.2 \mathrm{Ma}$. They also stated that the changes over this interval may have been the result of warm, saline, deep water (WSDW) production. This WSDW may have played an important role in deep water circulation between 60 and $56.2 \mathrm{Ma}$, and peaked during the LPTM and, following this period, deep waters are likely to have been produced at higher latitudes (Corfield and Cartlidge, 1992). The Southern Ocean could have been a source area for bottom waters as early as the Paleocene, with the exception of the interval between 60 and $56.2 \mathrm{Ma}$, climaxing near the Paleocene-Eocene boundary (Corfield and Cartlidge, 1992).

Deep ocean oxygen concentrations are primarily controlled by deep water formation processes. In the modern ocean, almost all dense, oxygen-rich waters are produced at high latitudes as a result of cold temperatures in combination with moderately high salinity (Kennett and Stott, 1991). Thomas (1990) suggested that during the LPTM there was a change from the formation of sinking, high latitude deep waters to the formation of deep to intermediate waters in the oceans by evaporation at lower latitudes. It is possible that these deep waters may have formed at sub-tropical latitudes, where evaporation strongly exceeds precipitation. As a result, heavy, dense, WSDW could have formed. This water would have likely been depleted in oxygen due to the lower solubility of oxygen at higher temperatures.

Today's oceanic circulation is thermohaline, which is essentially driven by the temperature differences between cold, well oxygenated, high latitudinal water. Zachos et al. (1993) stated that because the LPTM was a time of high temperatures and significant warmth, there would have been smaller planetary temperature gradients between high and low latitudes. During this time, deep sea water temperatures were similar to high latitudinal surface waters. The contribution of warm, saline waters to the overall deep circulation was likely to have been small, but as the higher latitudes began to warm during the mid-Paleocene, climaxing in the 
Chapter 4. Environmental conditions during the Late Paleocene-Early Eocene

Early Eocene, the density distribution of the ocean should have changed, shifting the ratio of deep water formation between high and low latitudes. At some threshold, deep ocean circulation may have changed into a form closer to a halothermal mechanism, driven by heavier, more dense, warm, saline surface waters originating from low to mid latitudes around 20-30 (Zachos et al. 1993; Kaiho et al. 1993). These surface waters would have been heavier and more dense than contemporaneous high latitudinal surface waters (Kaiho et al. 1993). There was a global dysaerobic event in the oceans associated with this change that is thought to have resulted from the switch from thermohaline to halothermal circulation (Killops et al. 2000). ODP data from the Southern Ocean suggest there was a short period of non-production of deep waters at high Southern latitudes at the Paleocene-Eocene boundary (Thomas, 1990).

During the LPTM, surface water temperatures had maximum temperatures surpassing 20 ${ }^{\circ} \mathrm{C}$. At the same time, bottom waters increased to $15{ }^{\circ} \mathrm{C}$ (Zachos et al. 1993; Kaiho et al. 1993). Warm, saline, shallow surface waters from mid to low latitudes may have sunk to the bottom of the ocean to drive slow circulation (Kaiho et al. 1993). When deep water temperatures reach or exceed $10{ }^{\circ} \mathrm{C}$, deep water circulation originating at high latitudes must disappear because heavy, cold water will not be produced at this temperature (De boar, 1986). Thus deep water oxygen levels would have declined if production was constant due to increasing oxygen consumption by biological activity. If circulation was slower this oxygen consumption would have been augmented (Kaiho et al. 1993).

It is possible that if oxygen consumption was sufficiently intense, bottom waters may have become anoxic. However, there is no record of the existence of total anoxia (Zachos et al. 1993).

Associated with the Late Paleocene-Early Eocene warming were major benthic foraminiferal extinctions. The process that caused the widespread extinctions was rapid $(\leq 3$ kyr) and had the capacity to affect great volumes of deep ocean very quickly. The extinctions were thought to have occurred at about the rate of replacement time of the Early Paleogene oceans (Kennett and Stott, 1991).

The absence of significant planktonic extinctions with respect to vast benthic extinctions and the nature of carbon and oxygen isotopic records have been suggested to reflect a decoupling of shallow and deep water ecosystems (Zachos et al. 1993). Elimination of ocean temperature gradients indicates vertical ocean mixing and homogenisation of nutrient 
Chapter 4. Environmental conditions during the Late Paleocene-Early Eocene

distributions. Whole ocean $\delta^{13} \mathrm{C}$ decreased by $2.5-3 \%$ in less than $10 \mathrm{kyr}$ during the Paleocene-Eocene warming episode. Such a rapid reduction in oceanic carbon composition requires an abrupt change in the flux of depleted carbon either to or from the ocean. A possible explanation was provided by Zachos et al. (1993), who suggested that lower global temperature gradients led to a decline in the vigor of atmospheric circulation, thus dampening wind driven upwelling and amplifying the reduction in nutrient flux to the oceans photic zone. As the result of vertical mixing and deep water turnover, nutrient fluxes would have declined, lowering the production and export of particulate carbon to and from the mixing layer.

\subsection{Isotopic and biological variations during the Paleocene to Eocene}

The deep sea $\delta^{13} \mathrm{C}$ record provides insights into the nature of global carbon cycle perturbations and on first order changes in deep sea circulation patterns (Zachos et al. 2001). Corfield and Cartlidge (1992) attributed some of the cause of the PCIM to increased ocean productivity, which in effect, implied greater photosynthesising biomass (and increased carbon burial). This may have had the effect of decreasing $p \mathrm{CO}_{2}$ of surface waters, resulting in the drawdown of atmospheric $\mathrm{CO}_{2}$ and a subsequent decline in $p \mathrm{CO}_{2}$. This decline may have led to global cooling (Corfield and Cartlidge, 1992), coinciding with the contemporaneous lowstand of sea level during this time (see Section 4.1) that gave way to a warming period during the early stages of the Late Paleocene.

The LPTM was marked by reduced oceanic turnover and decreases in global $\delta^{13} \mathrm{C}$ and marine productivity (Zachos et al. 1993). The event is characterised by a $\sim 3.0 \%{ }^{13} \mathrm{C}$ excursion of the marine, atmospheric, and terrestrial carbon reservoirs (Zachos et al. 2001). During the LPTM $\delta^{18} \mathrm{O}$ and $\delta^{13} \mathrm{C}$ records show a global dysaerobic event that is associated with the Paleocene warming. This dysaerobia affected benthic taxa but not surface planktonic species (Field et al. 1997; Zachos et al. 1993; Kennett and Stott, 1991). The climatic warming event was recognised in a pelagic sequence from the Maud Rise in the Atlantic sector of the Southern Ocean (Kennett and Stott, 1991).

$\delta^{18} \mathrm{O}$ analyses of foraminifera revealed abrupt, brief warming of deep ocean, high latitude surface waters coincident with a major extinction of benthic epifaunal foraminifera (Fig. 4.2). 
Chapter 4. Environmental conditions during the Late Paleocene-Early Eocene

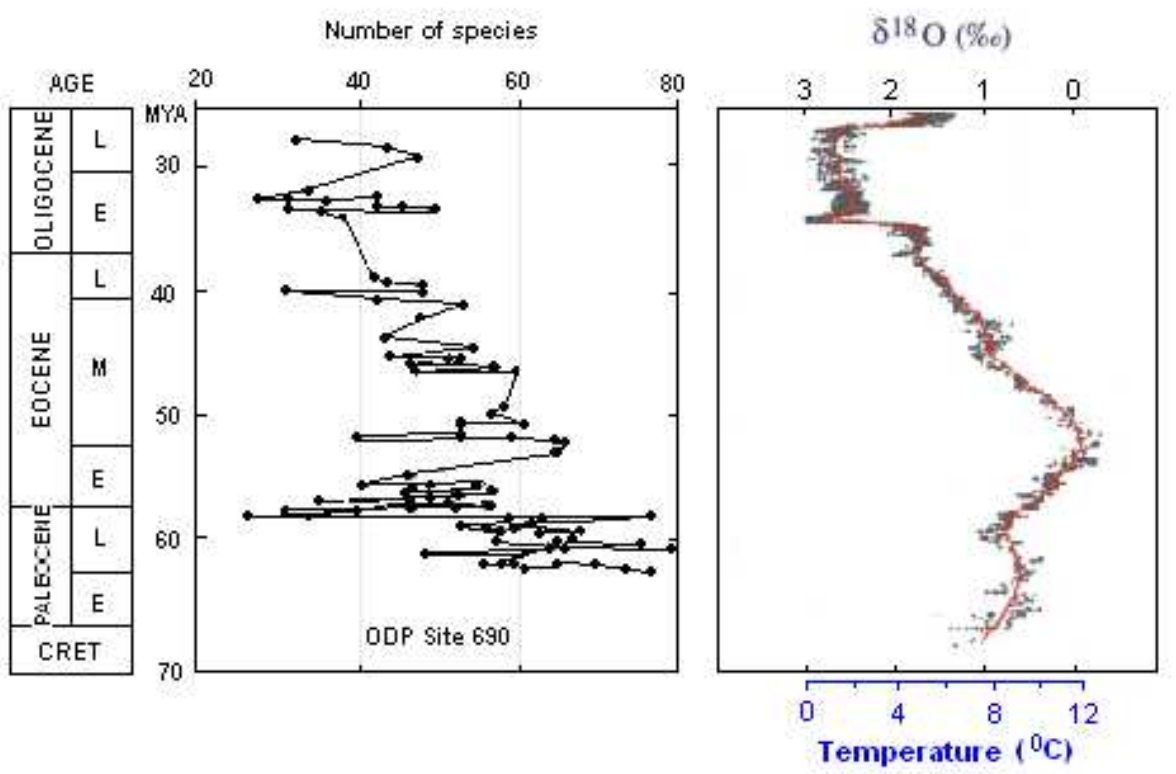

Figure 4.2 Lower Tertiary benthic epifaunal foraminifera variations at ODP 690 compared with global deep-sea oxygen isotope records. Modified from Zachos et al. (1993), and Zachos et al. (2001).

Thomas (1990) noted that benthic foraminiferal diversity dropped by $50 \%$ over a period of less than 25 kyr during the latest Paleocene, and this is corroborated by other authors such as Kennett and Stott (1991) who reported that benthic communities deeper than the continental shelf (>100 m depth) declined. During the widespread benthic epifaunal decline at the peak of the LPTM there were no extinctions of surface dwelling or terrestrial organisms on a comparable magnitude. This warming period was actually a time of low overall extinction rates (Thomas, 1990).

From the Late Paleocene to the Eocene, high latitudinal planktonic foraminiferal faunas and nannofossils became increasingly more diverse. Characteristic subtropical fauna and flora appeared in the Southern Oceans by Late Paleocene and reached peak abundance during the Early Eocene. These subtropical species slowly disappeared by the mid-Eocene as the temperature cooled to slightly higher than those temperatures before the Paleocene warming (Stott et al. 1990; Zachos et al. 1993).

Abundance records from the Late Paleocene to Early Eocene show deep sea benthic foraminiferal species underwent mass extinctions and epifaunal taxa disappeared. However, at the same time, planktonic biota diversity increased. This change is thought to have 
Chapter 4. Environmental conditions during the Late Paleocene-Early Eocene

resulted from a reduction of oxygen in bottom waters. The turnover in benthic species composition was abrupt, with most disappearances occurring just below the PaleoceneEocene boundary (Zachos et al. 1993).

Thomas (1990) has proposed that deep sea benthic foraminiferal faunas reflect the characteristics of deep waters. The benthic extinction event was likely due to changes in the oceanic conditions, with the replacement of a cold, well oxygenated water mass originating from high latitudes, with warm, heavy, saline, oxygen depleted water from mid to low latitudes, brought on by a change in water circulation patterns due to the LPTM warming (Field et al. 1997). Isotopic data from benthic foraminifera suggest that there was a short period of intense warm-saline water production during the Late Paleocene (Thomas, 1990).

Surface to deep water $\delta^{13} \mathrm{C}$ gradients, as reconstructed from planktonic and benthic foraminifera, briefly declined to near zero in less than $10 \mathrm{kyr}$ during the peak of the LPTM event (Zachos et al. 1993). Killops et al. (1996) stated that because benthic extinctions occurred at high latitudes and the main effect of the extinctions was encountered at intermediate depths, there was a loss in the oceanic temperature gradient between deep and surface waters. Kennett and Stott (1991) presented data that support this (Fig. 4.3).

$\delta 180$

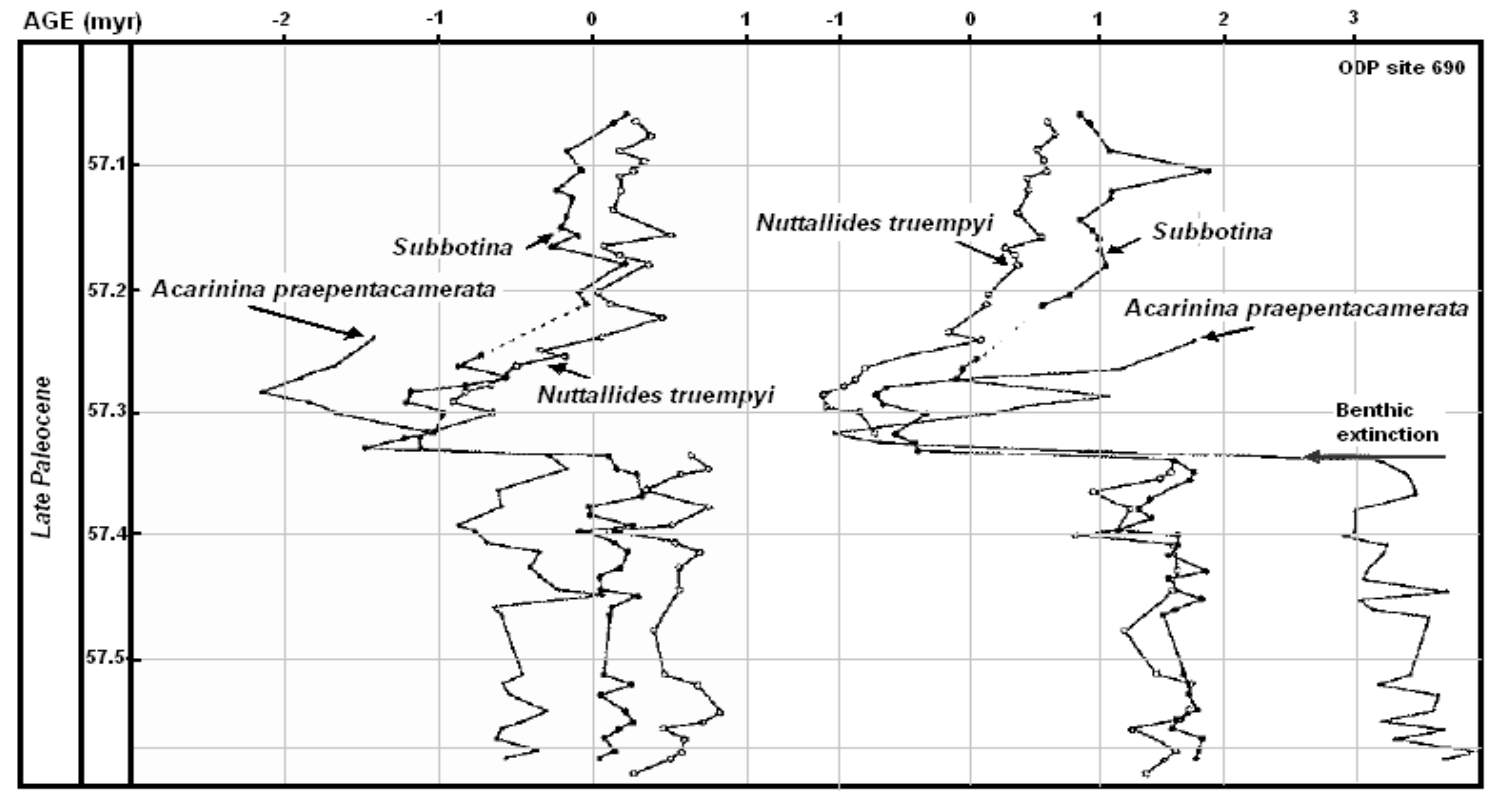

Figure 4.3 Late Paleocene $\delta^{18} \mathrm{O}$ and $\delta^{13} \mathrm{C}$ records from ODP site 690. Modified from Kennett and Stott (1991). 
Chapter 4. Environmental conditions during the Late Paleocene-Early Eocene

$\delta^{13} \mathrm{C}$ levels immediately preceding the extinction event are the highest in the entire Cenozoic. $\delta^{13} \mathrm{C}$ Benthic foraminiferal values at $57.32 \mathrm{Ma}$ are almost identical to contemporaneous surface water planktonic records, and there is usually a $2 \%$ gradient between surface and deep waters. Zachos et al. (1993) suggested that a decrease of over 3\%o in the $\delta^{13} \mathrm{C}$ records took place at this time.

From ODP research, Thomas (1990) concluded that the epifaunal benthic extinctions occurred over less than $25 \mathrm{kyr}$ and were followed by approximately $350 \mathrm{kyr}$ of low diversity and a strong dominance of planktonic species. This short interval is characterised by extremely low $\delta^{18} \mathrm{O}$ and $\delta^{13} \mathrm{C}$ values in benthic foraminiferal records. The dominance of infaunal species following the epifaunal reduction suggests the extinctions may have been caused by an increase in surface productivity, causing a strong increase in the abundance of infaunal biota. Such fauna appear to indicate high productivity of primary producers in the surface waters, good preservation of organic matter, and hence a lack of oxidation, or a combination of these. Dominance of infaunal taxa has been recorded from areas with a high flux of organic carbon to the ocean floor, or with low dissolved oxygen in the bottom waters.

As oceanic circulation during the LPTM was slow, more of the oxygen in deep waters must have been consumed by bacteria (Figures 4.3 and 4.4; Kaiho et al. 1993) and epifaunal species could not survive in such an oxygen-depleted environment.

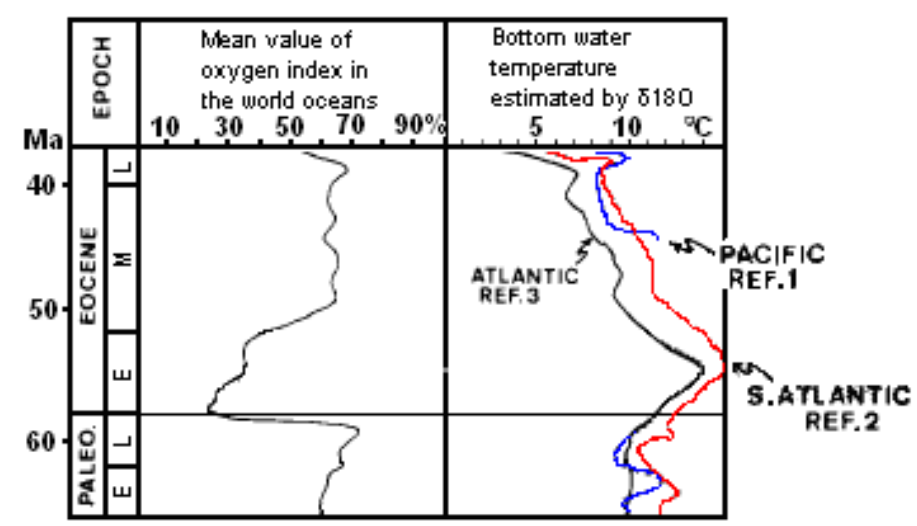

Figure 4.4 Low oxygen in the world's ocean compared with $\delta^{18} \mathrm{O}$ records. Modified from Kaiho et al. (1993). 
Chapter 4. Environmental conditions during the Late Paleocene-Early Eocene

Thomas (1990) later proposed that the benthic extinctions were most likely neither the result of an increase or decrease in surface productivity, but that rather the main cause was due to the deep ocean changes at the Paleocene-Eocene boundary.

Dylan Meadows, 2009. 
Chapter 5. Methods and Analytical Procedures

\section{CHAPTER 5 \\ Methods and analytical procedures}

Geochemical analyses were performed on cuttings and sidewall core samples from two wells from the Great South Basin, and four wells from the Canterbury Basin. Mass spectroscopy was undertaken at the GNS National Isotope Centre (Gracefield, Lower Hutt) using an elemental analyser isotope ratio mass spectrometer (EA-IRMS) to determine the total organic carbon (TOC) content, nitrogen content, and the carbon stable isotope ratio $\left(\delta^{13} \mathrm{C}\right)$ of each sample.

\subsection{Sampling}

Washed cuttings and sidewall cores were collected from the National Petroleum Core Store at Gracefield, Lower Hutt (now located in Featherston). Ninety cuttings samples were taken from four wells (Rakiura-1, Pukakai-1, Resolution-1, Endeavour-1, Clipper-1, and Galleon-1); five sidewall cores were also taken from Resolution-1. Samples were taken to approximately 75-200 $\mathrm{m}$ above and below the Tartan Formation interval, with a nominal sampling interval of 10-50 m. Within the Tartan Formation, closer sampling intervals of 3-5 $\mathrm{m}$ were used where possible.

In the present study, cuttings sample depths are not represented as a depth range (for example, Galleon-1; 2400-2405 m); instead, the depth intervals are given as the middle value of the depth range in order to clarify graphical interpretations and referencing (for example, Galleon-1; 2400-2405 $\mathrm{m}$ is represented as $2403 \mathrm{~m}$ ).

\subsection{Sample preparation}

Samples were prepared following the methods outlined by Rogers (pers. comm, 2008) and are as follows: Coarse cuttings fragments were hand picked using a microscope in order to select fragments that were most appropriate and closest resembled the average type of material from that particular cuttings sample. Selected cuttings and sidewall core samples were ground to fine powder using a mortar and pestle. This was then demineralised by placing the powdered sediment into $50 \mathrm{~mL}$ sample tubes, followed by the addition of approximately $10 \mathrm{~mL}$ of $1 \mathrm{~mol} \mathrm{HCl}$ to remove the inorganic carbon $\left(\mathrm{CO}_{3}{ }^{2-}\right)$. In some 
Chapter 5. Methods and Analytical Procedures

instances, $2 \mathrm{~mol} \mathrm{HCl}$, followed by heating at $50{ }^{\circ} \mathrm{C}$ in a water bath was used where it was thought that more intense treatment was required to remove more resilient calcareous material from the sample. The tubes were shaken vigorously and the acid left in the tube for at least 24 hours. Next, the acid was removed from the samples, and was neutralised by adding approximately $50 \mathrm{~mL}$ of distilled water and centrifuging at $3000 \mathrm{rpm}$ for 10 minutes. This neutralisation process was repeated and the powdered sediment allowed to dry in an oven at around $35-40{ }^{\circ} \mathrm{C}$.

\subsection{Mass Spectrometry}

In this study carbon isotopic ratios, nitrogen contents and organic contents were measured by Dr K. Rogers of GNS Science using a Europa Geo 20-20 isotope ratio mass spectrometer, interfaced to an ANCA-SL elemental analyser in continuous flow mode (EAIRMS). Around 6-80 mg of demineralised, powdered sediment was weighed in duplicate into tin capsules. The tin capsules were tightly crimped to avoid any trapping of air that would disturb the combustion process. After $\mathrm{O}_{2}$ injection, each capsule was dropped individually into a catalytic combustion furnace at a temperature around $1040{ }^{\circ} \mathrm{C}$. When $\mathrm{O}_{2}$ is introduced, tin oxidation creates an exothermic 'flash combustion' at $1800{ }^{\circ} \mathrm{C}$, ensuring complete combustion and oxidation of the sample (Grassineau, 2006). The carbon dioxide and nitrogen gases were resolved using gas chromatographic separation on a column at 60 ${ }^{\circ} \mathrm{C}$, and analysed simultaneously for isotopic abundance as well as total organic carbon (TOC) and nitrogen (\%N) content. Fry et al. (1992), and Grassineau (2006) provide detailed overviews of the stages concerning the method in which the $\delta^{13} \mathrm{C}$ data is derived.

Standards and blanks were included during the run for internal calibration. The analytical precision of the carbon isotopic measurements are $\pm 0.1 \%$. The final carbon isotopic ratio measurements are expressed using the standard $\delta$ notation (see Equation 5.1; White, 2001), as per mil (\%o) deviations relative to the Pee Dee Belemnite (V-PDB) standard for carbon.

Equation $5.1 \quad \delta^{13} \mathrm{C}=1000 \times\left[\left({ }^{13} \mathrm{C} /{ }^{12} \mathrm{C}\right)\right.$ sample $-\left({ }^{13} \mathrm{C} /{ }^{12} \mathrm{C}\right)$ standard $] /\left({ }^{13} \mathrm{C} /{ }^{12} \mathrm{C}\right)$ standard

$\mathrm{C} / \mathrm{N}$ ratios were calculated by dividing the TOC content by the total nitrogen content (TN or $\% \mathrm{~N}$ ) and multiplying by 14 (the atomic number of nitrogen) over 12 (the atomic number of carbon) (see Equation 5.2). 
Chapter 5. Methods and Analytical Procedures

Equation 5.2 $\mathrm{C} / \mathrm{N}=(\mathrm{TOC} / \mathrm{TN}) \times(14 / 12)$

Total Organic Carbon values recorded in the present study are accurate to one decimal place, and nitrogen contents are less accurate. Thus, $\mathrm{C} / \mathrm{N}$ calculations are rounded to the nearest whole number.

Dylan Meadows, 2009. 
Chapter 6. Results

\section{CHAPTER 6}

\section{$\underline{\text { Results }}$}

Geochemical analyses of six petroleum exploration wells from the Great South and Canterbury basins were undertaken using cuttings and sidewall core samples. Ninety cuttings and five sidewall core samples were selected, prepared (see Methods, Chapter 5) and analysed in duplicate for their TOC, $\delta^{13} \mathrm{C}$ and nitrogen contents using an elemental analyser isotope ratio mass spectrometer (EA-IRMS) (see Section 5.3). Results for TOC, $\delta^{13} \mathrm{C}$ and nitrogen contents for five other petroleum exploration wells from the Great South Basin (Takapu-1A, Hoiho-1C, Kawau-1A, Pakaha-1, and Toroa-1) are given in Meadows (2008) and in Appendix 3 here.

Graphical summaries of geochemical results are presented in Figures 6.1 to 6.6 for each well examined in this study, and Appendix 4 contains a complete list of all TOC, $\% \mathrm{~N}, \mathrm{C} / \mathrm{N}$ and $\delta^{13} \mathrm{C}$ values for each sample analysed.

\subsection{Rakiura-1}

Rakiura-1

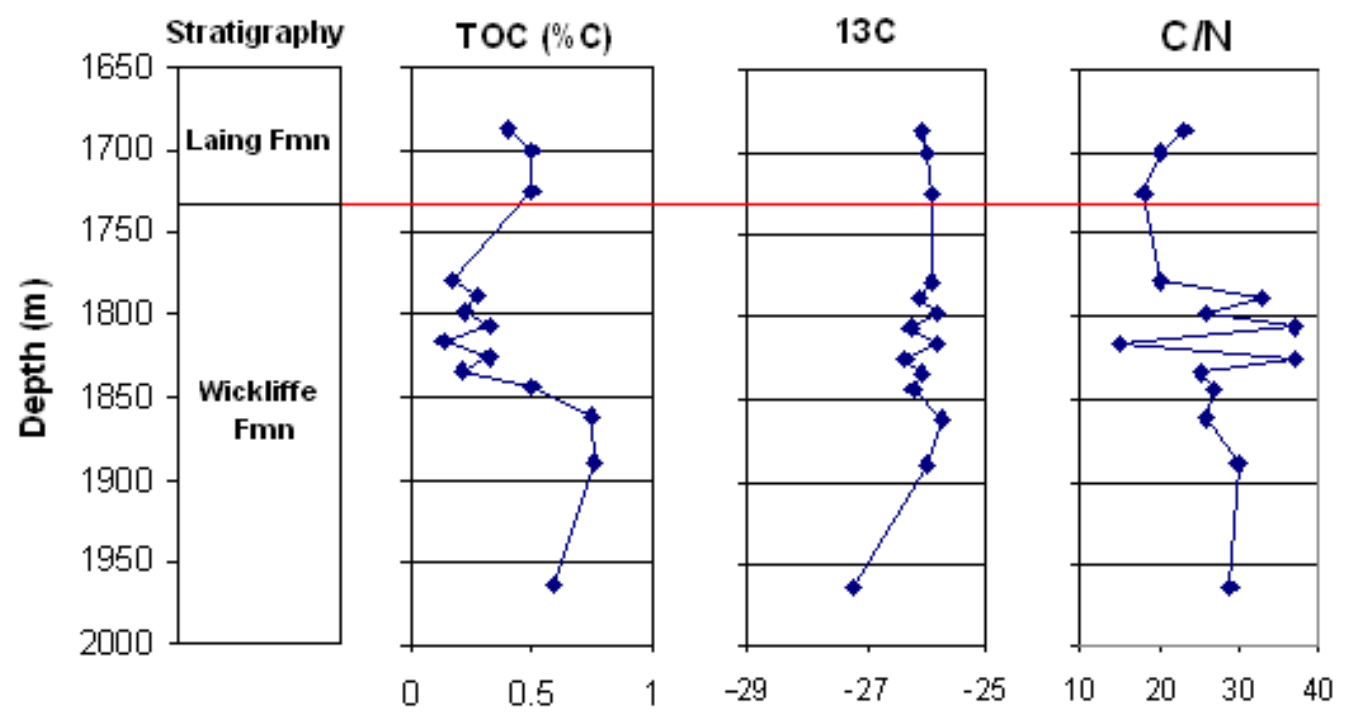

Figure 6.1 Geochemical results from Rakiura-1. 
Chapter 6. Results

\section{Total Organic Carbon (\%C)}

All cuttings samples analysed from this well have low TOC contents, consistent with the absence of the Tartan Formation. Samples selected range from Early Teurian to Late Waipawan \{based on interval depths presented by Cook et al. (1999)\}; none however recorded TOC values exceeding 1.0\%. The three deepest samples from $1964 \mathrm{~m}, 1889 \mathrm{~m}$, and $1861 \mathrm{~m}$ contain the highest TOC values of $0.6,0.8$, and $0.7 \%$ respectively. The remaining eleven samples have low TOC contents that range from 0.1 to $0.5 \%$, with the minimum value of $0.1 \%$ having been recorded in the sample from $1816 \mathrm{~m}$.

$\delta^{13} \mathrm{C}$

For the purposes of this study, $\delta^{13} \mathrm{C}$ values with an isotopic value around $-25 \%$ and lighter are considered isotopically light, while values around $-22 \%$ and heavier are considered heavy.

All samples examined in this well exhibit isotopically light $\delta^{13} \mathrm{C}$, with a narrow range, from -27.2 to $-25.7 \%$ o (1.5\% variation over 14 samples spanning $276 \mathrm{~m})$.

The deepest sample from $1964 \mathrm{~m}$ contains the lightest recorded $\delta^{13} \mathrm{C}$ value $(-27.2 \%)$. Over the following 13 samples, from $1889 \mathrm{~m}$ to $1688 \mathrm{~m}, \delta^{13} \mathrm{C}$ values range from -26.3 to $-25.7 \%$ o (a $0.6 \%$ variation over these 13 samples).

\section{Nitrogen content $(\% \mathrm{~N})$}

Nitrogen contents from all samples in this well are very low, and all recorded values below $0.1 \%$.

\section{Carbon/Nitrogen Ratio}

The deepest five samples analysed, from $1964 \mathrm{~m}$ to $1834 \mathrm{~m}$, all have moderate C/N ratios that range from 25 to 30 . A considerable increased was recorded in the sample from $1825 \mathrm{~m}$, which has a high ratio of 37 . This is followed by a relatively low $\mathrm{C} / \mathrm{N}$ ratio in the sample from $1816 \mathrm{~m}$ with a value of 15 , which is the lowest value recorded in this well. Above this, the following sample from $1807 \mathrm{~m}$ has a high C/N ratio of 37. Samples from $1798 \mathrm{~m}$ and $1789 \mathrm{~m}$ recorded ratios of 26 and 33 respectively. The following four samples, from $1779 \mathrm{~m}$ to $1688 \mathrm{~m}$, have moderate to low ratios that range between 18 and 23. There is a general 
Chapter 6. Results

trend throughout the sample set which appears to display increasingly higher $\mathrm{C} / \mathrm{N}$ ratios with increasing depth.

\subsection{Pukaki-1}

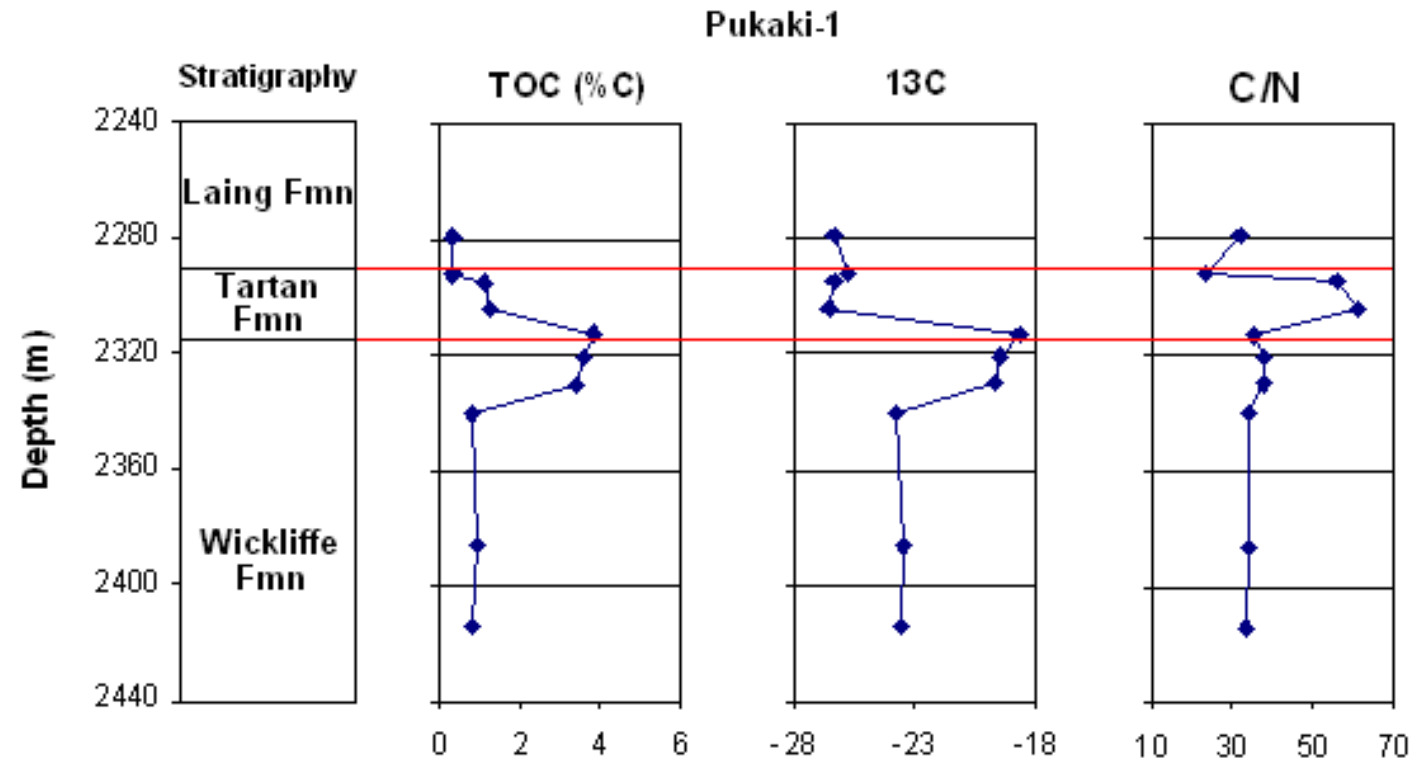

Figure 6.2 Geochemical results from Pukaki-1.

\section{Total Organic Carbon (\%C)}

The three deepest samples examined, from $2414 \mathrm{~m}$ to $2340 \mathrm{~m}$, have low to moderate TOC contents that range from 0.8 to $0.9 \%$. The first noticeable increase in TOC content was recorded in the sample from $2330 \mathrm{~m}$, with a value of $3.4 \%$. The two samples immediately above this, from $2321 \mathrm{~m}$ and $2313 \mathrm{~m}$ also contain high TOC concentrations, with 3.6 and $3.9 \%$ respectively. The sample from $2313 \mathrm{~m}(3.9 \%)$ has the highest recorded concentration of TOC of all samples investigated in this well. These three high TOC samples lie close to and within the Tartan Formation interval as identified by Schioler and Roncaglia (2008), once sample cavings have been accounted for (sample contamination from cuttings, where samples from higher depths are incorporated into samples received from deeper in the borehole). The next two samples, from $2304 \mathrm{~m}$ and $2295 \mathrm{~m}$, have moderate TOC values of 1.3 and $1.1 \%$ respectively. The shallowest samples from $2292 \mathrm{~m}$ and $2279 \mathrm{~m}$ have low TOC concentrations, each with a value of $0.3 \%$. 
Chapter 6. Results

$\delta^{13} \mathrm{C}$

The deepest three samples examined in this well, from $2414 \mathrm{~m}, 2386 \mathrm{~m}$, and $2340 \mathrm{~m}$, have very similar $\delta^{13} \mathrm{C}$ values of $-23.6,-23.5$, and $-23.8 \%$ respectively, with a mean value of 23.6\% . The following three samples from $2330 \mathrm{~m}, 2321 \mathrm{~m}$, and $2313 \mathrm{~m}$ recorded isotopically heavy $\delta^{13} \mathrm{C}$ values of $-19.7,-19.4$, and $-18.7 \%$ respectively. The mean $\delta^{13} \mathrm{C}$ for these three samples is $-19.3 \%$. The sample from $2313 \mathrm{~m}(-18.7 \%$ o $)$ recorded the heaviest $\delta{ }^{13} \mathrm{C}$ value of all samples in Pukaki-1. The remaining four samples from $2304 \mathrm{~m}$ to $2279 \mathrm{~m}$ all contain light $\delta^{13} \mathrm{C}$ values ranging from -26.6 to $-25.8 \%$, with an average of $-26.3 \%$.

It is evident from the data presented in Figure 6.2 that the samples below the heavy isotopic excursion (from $2330 \mathrm{~m}$ to $2313 \mathrm{~m}$ ) are much heavier than those above the isotopic excursion.

\section{Nitrogen content $(\% N)$}

Samples from $2414 \mathrm{~m}$ to $2340 \mathrm{~m}$ have low nitrogen contents, all below $0.1 \%$. The three samples from $2330 \mathrm{~m}, 2321 \mathrm{~m}$, and $2313 \mathrm{~m}$ display higher values, each containing $0.1 \%$ nitrogen. These three samples also have the highest TOC and heaviest $\delta^{13} \mathrm{C}$ values of all samples examined in this well. The four uppermost samples, from $2304 \mathrm{~m}$ to $2279 \mathrm{~m}$, each have nitrogen contents of less than $0.1 \%$.

\section{Carbon/Nitrogen Ratio}

The six deepest samples from $2414 \mathrm{~m}$ to $2313 \mathrm{~m}$ all contain high $\mathrm{C} / \mathrm{N}$ ratios ranging from 33 to 38. Samples from $2304 \mathrm{~m}$ and $2295 \mathrm{~m}$ both recorded exceptionally high C/N ratios of 61 and 56 respectively. The two shallowest samples from $2292 \mathrm{~m}$ and $2279 \mathrm{~m}$ have moderate ratios of 23 and 32 respectively. The mean $\mathrm{C} / \mathrm{N}$ ratio for all samples in this well is 39 . 
Chapter 6. Results

\subsection{Resolution-1}

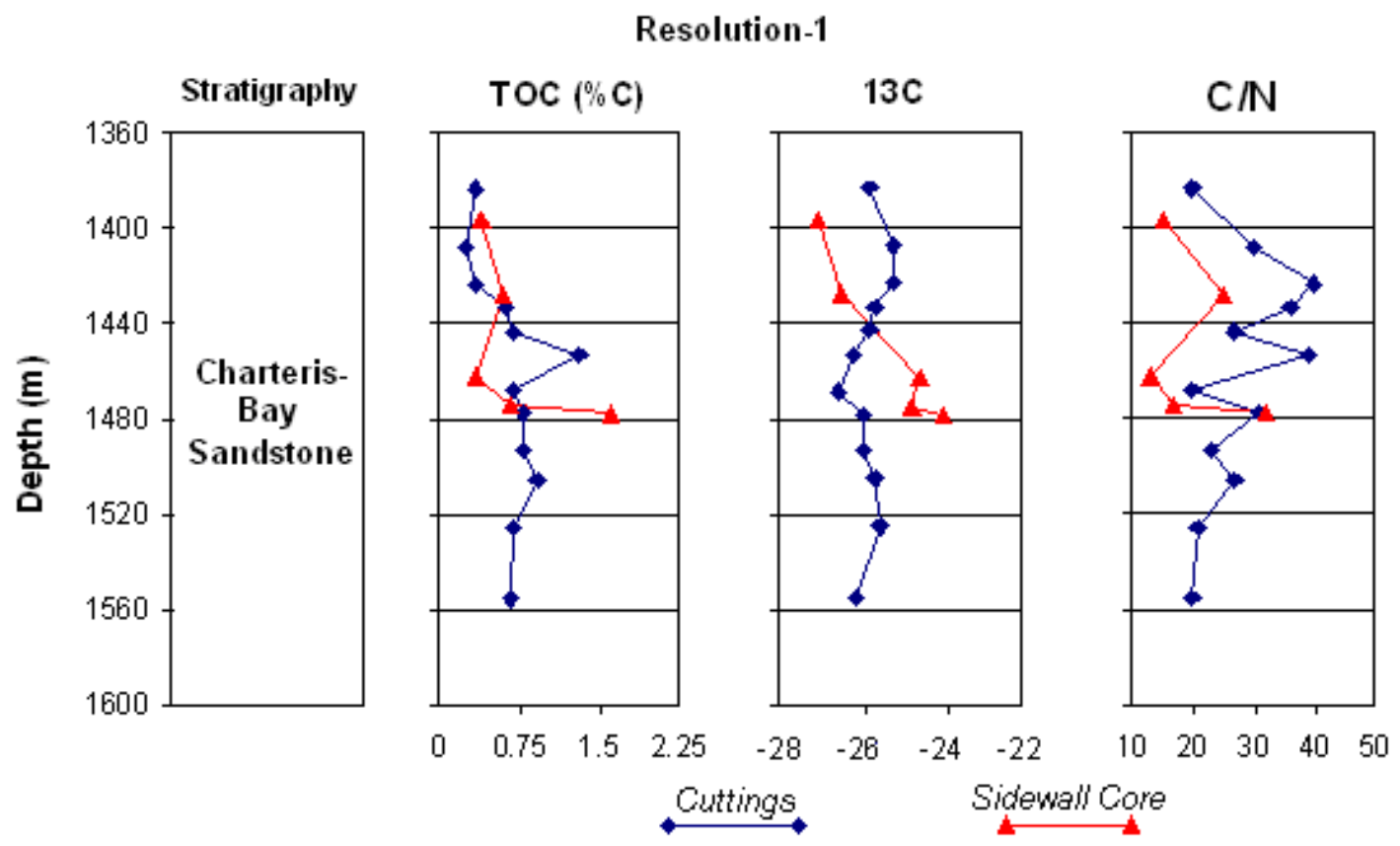

Figure 6.3 Geochemical results from Resolution-1.

Total Organic Carbon (\%C)

Sidewall cores:

Of the five sidewall cores analysed from this well, only one recorded a TOC value greater than $1.0 \%$. This came from the deepest sample from $1478 \mathrm{~m}$, with a value of $1.6 \%$. Above this, from $1474.5 \mathrm{~m}$ to $1396.5 \mathrm{~m}$, TOC contents are low, ranging from 0.3 to $0.7 \%$.

\section{Cuttings:}

Cuttings samples from $1555 \mathrm{~m}$ through $1468 \mathrm{~m}$ have low to moderate TOC values ranging from 0.7 to $0.9 \%$. The sample from $1453 \mathrm{~m}$ has the highest TOC concentration of all Resolution-1 cuttings analysed with a value of $1.3 \%$. This is considered to be a relatively low value compared with many samples around this interval from other wells investigated in this study. Samples from $1443 \mathrm{~m}$ through $1383 \mathrm{~m}$ gradually display lower concentrations of TOC, from $0.7 \%$ at $1443 \mathrm{~m}$ to $0.3 \%$ in the sample from $1383 \mathrm{~m}$. The average TOC content for all cuttings samples is $0.7 \%$, identical to the mean of the sidewall core samples.

Dylan Meadows, 2009. 
Chapter 6. Results

$\delta^{13} \mathrm{C}$

Sidewall cores:

Only five sidewall core samples were examined in this well from the $1478 \mathrm{~m}$ to $1396.5 \mathrm{~m}$ interval.

A trend observed from the data shows that the isotopic $\delta^{13} \mathrm{C}$ becomes heavier with increasing depth (as shown in Figure 6.3). The deepest sample, from $1478 \mathrm{~m}$, has the heaviest $\delta^{13} \mathrm{C}$ value with $-23.9 \%$. The overlying samples from $1474.5 \mathrm{~m}$ and $1462.5 \mathrm{~m}$ recorded $\delta^{13} \mathrm{C}$ values of -24.7 and $-24.5 \%$ respectively. The shallowest samples from $1428 \mathrm{~m}$ and $1396.5 \mathrm{~m}$ each displayed isotopically light $\delta^{13} \mathrm{C}$ with values of -26.5 and $-27.0 \%$ o respectively. The mean value for this set of sidewall core samples was $-25.3 \%$.

\section{Cuttings:}

Although many of the cuttings sampled in Resolution-1 are of similar depths to the above reported sidewall cores, the $\delta^{13} \mathrm{C}$ data obtained varies considerably. Over the twelve cuttings samples investigated from this well, there is relatively little variation in $\delta^{13} \mathrm{C}$. All samples lie between -26.6 and $-25.1 \%$ (a $1.5 \%$ difference over the $172 \mathrm{~m}$ sample set), with a mean value of $-25.8 \%$. The mean $\delta^{13} \mathrm{C}$ for cuttings samples is $0.5 \%$ lighter than the mean $\delta^{13} \mathrm{C}$ from the sidewall core samples.

All $\delta^{13} \mathrm{C}$ values from cuttings in this well are considered to be isotopically light.

\section{Nitrogen content $(\% N)$}

All five sidewall core samples analysed show low nitrogen contents, with values less than $0.1 \%$.

As in the sidewall core samples, low nitrogen contents of less than $0.1 \%$ are recorded for all twelve cuttings samples.

\section{Carbon/Nitrogen Ratio}

Sidewall cores:

Of the five sidewall core samples examined from this well only one recorded a moderate to high $\mathrm{C} / \mathrm{N}$ ratio. This was from $1478 \mathrm{~m}$ with a value of 32 . The remaining four samples from $1474.5 \mathrm{~m}$ to $1396.5 \mathrm{~m}$ recorded ratios that range from 13 to 25 . The lowest value of 13 
Chapter 6. Results

(from $1462.5 \mathrm{~m}$ ) is the lowest $\mathrm{C} / \mathrm{N}$ ratio of all samples examined in Resolution-1 (including cuttings samples). The mean $\mathrm{C} / \mathrm{N}$ ratio for these sidewall core samples was 20 .

\section{Cuttings:}

The two deepest samples examined, from $1555 \mathrm{~m}$ and $1525 \mathrm{~m}$, have $\mathrm{C} / \mathrm{N}$ ratios of 20 and 21 respectively. A ratio of 27 was recorded in the sample from $1505 \mathrm{~m}$, followed by 23 from $1493 \mathrm{~m}$. A moderate ratio of 31 was recorded in the sample from $1478 \mathrm{~m}$. The following two samples from $1468 \mathrm{~m}$ and $1453 \mathrm{~m}$ have vastly different ratios from one another despite a relatively small sampling gap, with values of 20 and 39 respectively. Two samples from 1443 $\mathrm{m}$ and $1433 \mathrm{~m}$ have ratios of 27 and 36. The highest recorded $\mathrm{C} / \mathrm{N}$ ratio in this well was identified in the sample from $1423 \mathrm{~m}$, with a ratio of 40 . The two shallowest samples from $1408 \mathrm{~m}$ and $1383 \mathrm{~m}$ have $\mathrm{C} / \mathrm{N}$ ratios of 30 and 20 respectively.

Throughout the twelve cuttings samples analysed there is little consistency from one sample to the next (Figure 6.3). However, the overall trend throughout the well suggests that the $\mathrm{C} / \mathrm{N}$ ratio lessens downwards in the well. The average $\mathrm{C} / \mathrm{N}$ ratio over this set of Resolution- 1 cuttings is 28 , compared to the mean ratio of 20 recorded from the sidewall core samples.

\subsection{Endeavour-1}

\section{Endeavour-1}

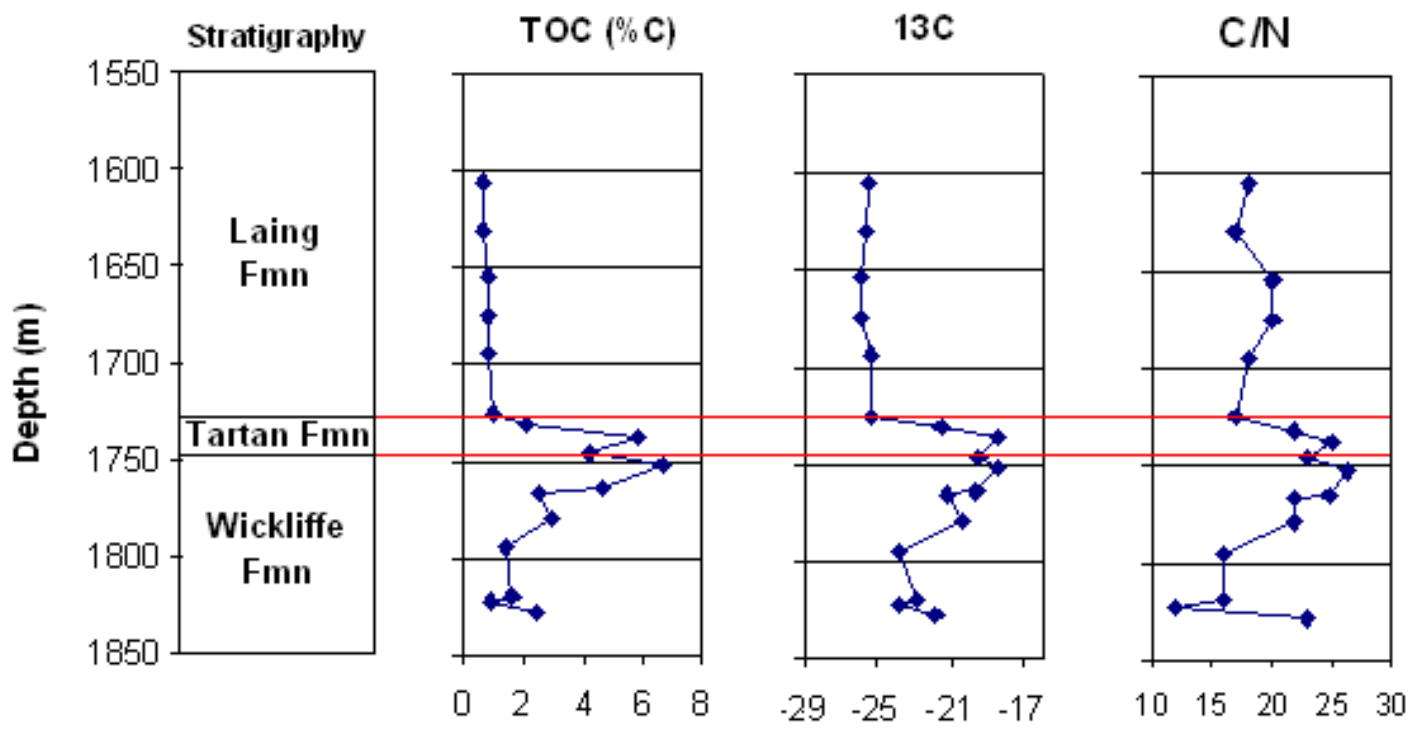

Figure 6.4 Geochemical results from Endeavour-1. 
Chapter 6. Results

\section{Total Organic Carbon (\%C)}

The deepest sample analysed for this well, from $1828 \mathrm{~m}$, has a relatively high TOC content of $2.4 \%$. This sample is approximately of mid-Paleocene age (inferred from Crown Minerals, 2008c). The next three samples, from $1822 \mathrm{~m}$ to $1795 \mathrm{~m}$, have moderate TOC contents ranging from 0.9 to $1.6 \%$. A significant increase in the TOC content is first observed in the sample from $1779 \mathrm{~m}$ (3.0\%). At $1766 \mathrm{~m}$ a slightly lower value of $2.5 \%$ was recorded, increasing to $4.6 \%$ in the sample from $1764 \mathrm{~m}$. The sample from $1752 \mathrm{~m}$ has the highest recorded TOC content of all Endeavour-1 samples investigated here, with a value of $6.6 \%$. The overlying sample from $1746 \mathrm{~m}$ has a noticeably lower TOC content of $4.2 \%$, followed by a significantly higher value of $5.9 \%$ in the sample from $1737 \mathrm{~m}$. The sample from $1731 \mathrm{~m}$ is the shallowest to display a significantly elevated TOC content $(2.1 \%)$. The remaining six samples above these elevated TOC samples have recorded low to moderate TOC values that generally show decreasing TOC values upwards in the well, from $1.0 \%$ in the sample from $1725 \mathrm{~m}$ to $0.7 \%$ in the shallowest sample analysed from $1605 \mathrm{~m}$.

It is evident from the data that the TOC content of samples below the elevated TOC interval (from $1779 \mathrm{~m}$ to $1731 \mathrm{~m}$ ) is higher than that of samples above the elevated TOC interval.

$\delta^{13} \mathrm{C}$

The deepest sample analysed $(1828 \mathrm{~m})$ has a relatively heavy $\delta^{13} \mathrm{C}$ value of $-21.9 \%$. The following three samples from $1822 \mathrm{~m}, 1819 \mathrm{~m}$, and $1795 \mathrm{~m}$ recorded moderately heavy $\delta^{13} \mathrm{C}$ values of $-23.9,-22.9$, and $-23.9 \%$ respectively. Over the $33 \mathrm{~m}$ depth that covers these deepest four samples there is $2.0 \%$ of variation in $\delta^{13} \mathrm{C}$. The next seven samples from 1779 $\mathrm{m}$ through $1731 \mathrm{~m}$ have all recorded heavy $\delta^{13} \mathrm{C}$ values. The deepest of these heavy $\delta^{13} \mathrm{C}$ samples $(1779 \mathrm{~m})$ recorded a $\delta^{13} \mathrm{C}$ value of $-20.4 \%$. The next sample from $1766 \mathrm{~m}$ has a slightly lighter value of $-21.3 \%$, and the following four samples from $1764 \mathrm{~m}$ to $1737 \mathrm{~m}$ contain the heaviest $\delta^{13} \mathrm{C}$ values in this well. The sample from $1764 \mathrm{~m}$ recorded a $\delta^{13} \mathrm{C}$ value of $-19.7 \%$, followed by $-18.5 \%$ in the sample from $1752 \mathrm{~m}$. A slightly lighter value of $19.5 \%$ was recorded from $1746 \mathrm{~m}$, followed by a return to $-18.5 \%$ in the sample from 1737 $\mathrm{m}$. Both of the samples from $1752 \mathrm{~m}$ and $1737 \mathrm{~m}$ contain $\delta^{13} \mathrm{C}$ values of $-18.5 \%$, which is the heaviest value obtained from these set of analyses. The final sample to display a heavy isotopic character came from $1731 \mathrm{~m}(-21.5 \%)$. Over the $48 \mathrm{~m}$ sample depth that covered 
Chapter 6. Results

these seven samples there is $3.0 \%$ variation in $\delta^{13} \mathrm{C}$, with a mean value of $-19.9 \%$. The six overlying samples from $1725 \mathrm{~m}$ to $1605 \mathrm{~m}$ all contain isotopically light $\delta^{13} \mathrm{C}$, ranging from 26.0 to $-25.3 \%$ o $(0.7 \%$ variation over $120 \mathrm{~m})$. The mean value for these six samples is $25.6 \%$, which is considerably lighter than the mean value of samples between $1779 \mathrm{~m}$ and $1731 \mathrm{~m}(-19.9 \%)$, and of samples below the heavy isotopic excursion, from $1828 \mathrm{~m}$ to 1795 $\mathrm{m}$ which have a mean $\delta^{13} \mathrm{C}$ of $-23.2 \%$.

\section{Nitrogen content $(\% \mathrm{~N})$}

The four samples from $1828 \mathrm{~m}$ through $1795 \mathrm{~m}$ have nitrogen contents of $0.1 \%$ or less. A significant increase in the nitrogen content is observed in the overlying seven samples from $1779 \mathrm{~m}$ to $1731 \mathrm{~m}$, where values range from 0.1 to $0.3 \%$. These samples also contain much higher TOC contents, and have isotopically heavier $\delta^{13} \mathrm{C}$ values than those samples with low nitrogen contents. The six samples above $1731 \mathrm{~m}$ all have very low nitrogen values of less than $0.1 \%$.

\section{Carbon/Nitrogen Ratio}

The deepest sample analysed from this well, from $1828 \mathrm{~m}$, recorded a C/N ratio of 23 . The three following samples from $1822 \mathrm{~m}$ to $1795 \mathrm{~m}$ have low ratios ranging between 12 and 16. These lowermost four samples have a mean $\mathrm{C} / \mathrm{N}$ ratio of 17 . There is a distinctive increase over the next seven samples from $1779 \mathrm{~m}$ to $1731 \mathrm{~m}$, where ratios range from 22 to 26 , with a mean value of 24 . The six shallowest samples from $1725 \mathrm{~m}$ to $1605 \mathrm{~m}$ have lower ratios of from 17 to 20 , with a mean of 18 . It is evident (Figure 6.4) that the sample set is separated into three sections. Between $1828 \mathrm{~m}$ and $1795 \mathrm{~m}$ there is a low mean $\mathrm{C} / \mathrm{N}$ ratio (17), followed by a considerable increase in the average $\mathrm{C} / \mathrm{N}$ ratio of samples between 1779 $\mathrm{m}$ and $1731 \mathrm{~m}$ (24). Above this, from $1725 \mathrm{~m}$ to $1605 \mathrm{~m}$, is a return to a lower mean value of 18.

Low to moderate $\mathrm{C} / \mathrm{N}$ ratios are dominant for the seventeen samples examined from Endeavour-1. The highest value of 26 was recorded in the sample from $1752 \mathrm{~m}$, whereas the lowest ratio of 12 came from a deep sample from $1822 \mathrm{~m}$. The latter recorded the lowest $\mathrm{C} / \mathrm{N}$ ratio of all samples examined in this set of analyses. The average $\mathrm{C} / \mathrm{N}$ ratio calculated for all samples in this well is 20 , which is the lowest mean value for any of the six wells 
Chapter 6. Results

investigated in this study; however, two wells investigated by Meadows (2008), Pakaha-1 and Toroa-1 (sidewall cores), have recorded lower mean $\mathrm{C} / \mathrm{N}$ ratios (Appendix 3).

\subsection{Galleon-1}

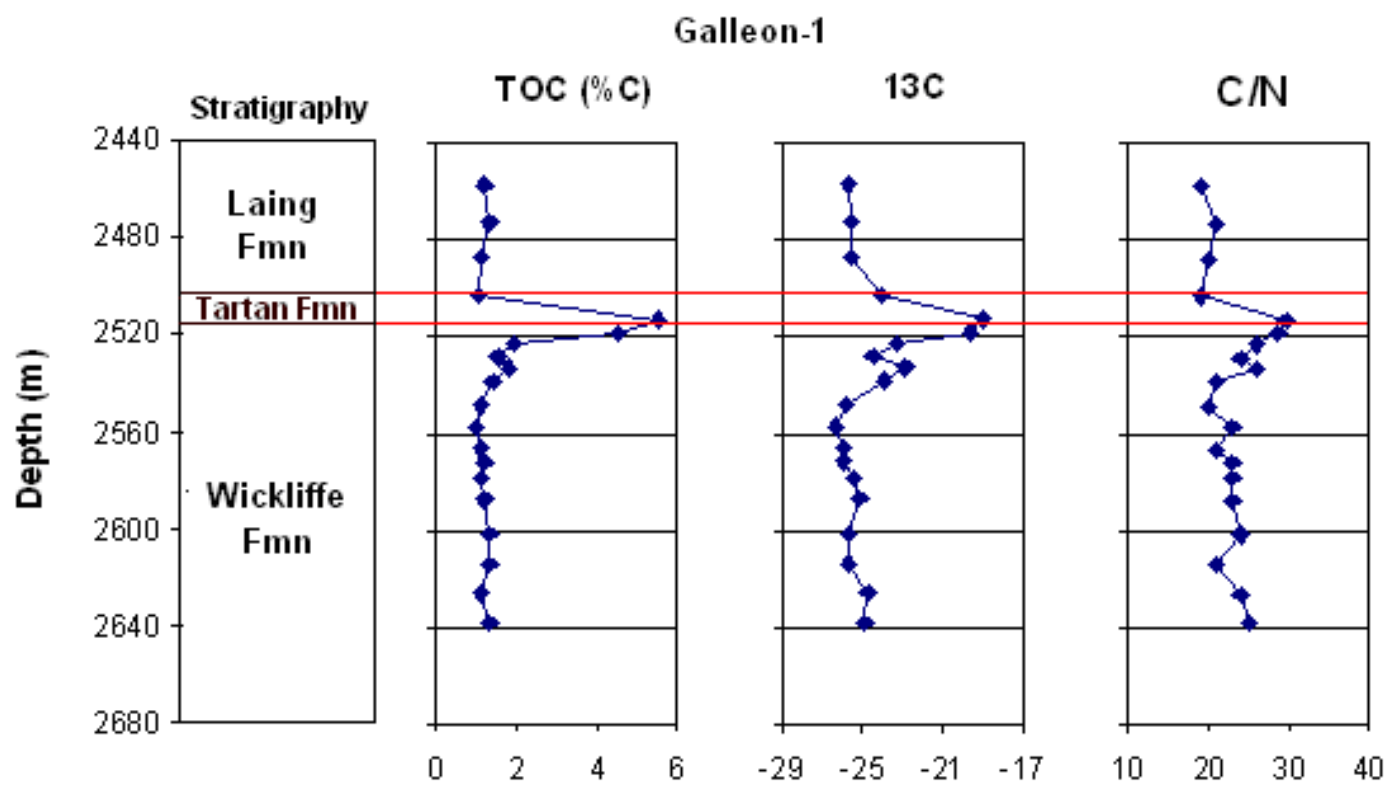

Figure 6.5 Geochemical results from Galleon-1.

\section{Total Organic Carbon (\%C)}

Of the twenty cuttings samples examined only four recorded TOC values exceeding $1.5 \%$. The eleven deepest samples from $2638 \mathrm{~m}$ through $2538 \mathrm{~m}$ all have very consistent TOC contents which range from 1.0 to $1.4 \%$, with a mean value of $1.2 \%$. These samples lie within the earliest to mid-Paleocene time interval (Crown Minerals, 2008c). The sample from 2533 $\mathrm{m}$ is the deepest to display an elevated TOC content $(1.8 \%)$, followed by a slightly lower value of $1.5 \%$ in the sample from $2528 \mathrm{~m}$. Over the next three samples from $2523 \mathrm{~m}, 2518$ $\mathrm{m}$, and $2513 \mathrm{~m}$ there are gradual increases in TOC content with recorded values of 2.0, 4.5 and $5.6 \%$ respectively. The sample from $2513 \mathrm{~m} \mathrm{(5.6 \% )}$ contains the highest concentration of TOC in this well. These five consecutive moderate to high TOC concentration samples have a mean value of $3.1 \%$. Above this, a return to low-moderate TOC contents is observed. The four samples from $2503 \mathrm{~m}$ to $2458 \mathrm{~m}$, which represent the uppermost Paleocene to earliest Eocene, have values ranging from 1.1 to $1.4 \%$, with a mean TOC content of $1.2 \%$, similar to that of the deepest samples.

Dylan Meadows, 2009. 
Chapter 6. Results

$\delta^{13} \mathrm{C}$

The eleven lowermost samples from $2638 \mathrm{~m}$ through $2538 \mathrm{~m}$ all contain isotopically light $\delta^{13} \mathrm{C}$ ranging from -26.4 to $-24.0 \%$ o (2.4\%o variation over $\left.100 \mathrm{~m}\right)$, with a average value of 25.4\% . A trend observed throughout these eleven samples shows the $\delta^{13} \mathrm{C}$ value becoming isotopically lighter the shallower the sample is located in the well. The sample from $2533 \mathrm{~m}$ contains a moderately heavy $\delta^{13} \mathrm{C}$ value of $-22.9 \%$, followed by an isotopically light sample from $2528 \mathrm{~m}(-24.5 \%$ ) and, above this, at $2523 \mathrm{~m}$, a moderately heavy value of $-23.3 \%$. The two samples from $2518 \mathrm{~m}$ and $2513 \mathrm{~m}$ both contain isotopically heavy $\delta^{13} \mathrm{C}$, with -19.6 and $-19.0 \%$ respectively. These two samples are the heaviest recorded from all samples examined from Galleon-1. The four shallowest samples from $2503 \mathrm{~m}$ to $2458 \mathrm{~m}$ all contain isotopically light $\delta^{13} \mathrm{C}$, ranging from -25.7 to $-24.1 \%$ (with a mean value of $-25.2 \%$ ). Samples above the heavy isotopic excursion have a similar mean value to those samples below it.

\section{Nitrogen content $(\% \mathrm{~N})$}

Of the fourteen samples analysed from $2638 \mathrm{~m}$ through $2523 \mathrm{~m}$, ten have nitrogen contents of $0.1 \%$, and the remaining four have values below $0.1 \%$. Only two samples from this well have nitrogen contents above $0.1 \%$. These samples $(2518 \mathrm{~m}$ and $2513 \mathrm{~m})$ each recorded values of $0.2 \%$, and also have the highest TOC contents and heaviest $\delta^{13} \mathrm{C}$ values recorded in this well. The four samples above $2513 \mathrm{~m}$ all have significantly lower nitrogen contents, all less than $0.1 \%$.

\section{Carbon/Nitrogen Ratio}

The eleven samples analysed, from $2638 \mathrm{~m}$ to $2538 \mathrm{~m}$, have similar C/N values ranging from 20 to 25. Samples from $2533 \mathrm{~m}, 2528 \mathrm{~m}$, and $2523 \mathrm{~m}$ recorded C/N ratios of 26, 24, and 26 respectively. The highest $\mathrm{C} / \mathrm{N}$ ratios of 29 and 30 were recorded in the samples from $2518 \mathrm{~m}$ and $2513 \mathrm{~m}$ respectively. The four shallowest samples from $2503 \mathrm{~m}$ to $2458 \mathrm{~m}$ all have similar ratios that range between 19 and 21. The overall mean value for these twenty samples is 23 , with a relatively narrow range between 19 and 30 . 
Chapter 6. Results

\subsection{Clipper-1}

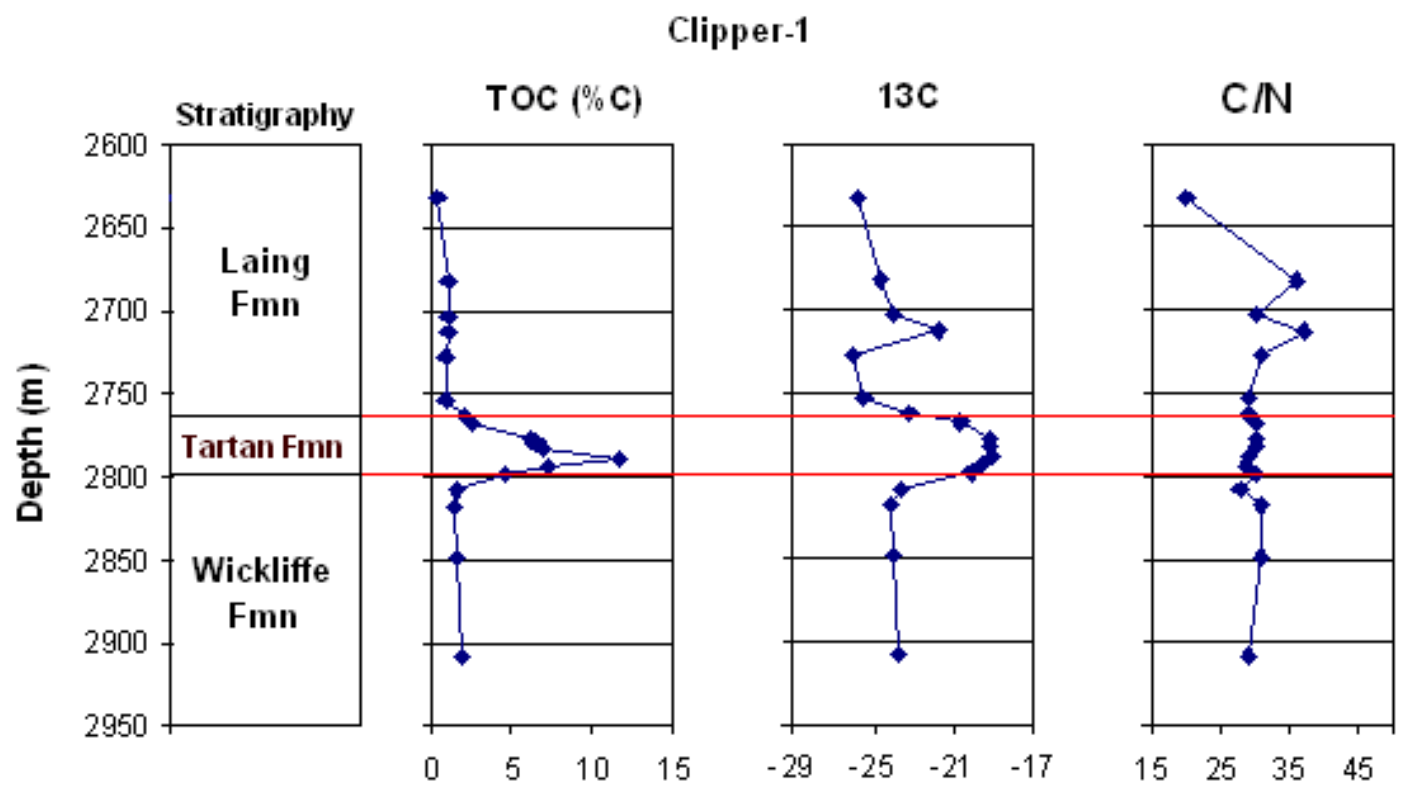

Figure 6.6 Geochemical results from Clipper-1.

Total Organic Carbon (\%C)

The deepest four samples examined, from $2908 \mathrm{~m}$ through $2808 \mathrm{~m}$, contain moderate TOC contents ranging from 1.3 to $1.8 \%$, with a mean value of $1.5 \%$. The sample ages are mid-Paleocene (Crown Minerals, 2008c). The overlying seven samples of mid to Late Paleocene age all have high TOC contents. The deepest of these, from $2798 \mathrm{~m}$ has a TOC content of $4.6 \%$ followed by a gradual rise in carbon content over the next two samples from $2793 \mathrm{~m}(7.1 \%)$ and $2788 \mathrm{~m}(11.7 \%)$. The sample from $2788 \mathrm{~m}$ has the highest TOC content of all samples examined in this set of analyses by a considerable margin (the highest TOC content outside of this well was a value of 6.6\%, recorded from Endeavour-1). There is a gradual decrease in the TOC content over the following four samples, from $6.8 \%$ in the sample from $2783 \mathrm{~m}$, to $2.0 \%$ in the sample from $2763 \mathrm{~m}$. The shallowest six samples from $2753 \mathrm{~m}$ to $2633 \mathrm{~m}$ represent the uppermost Paleocene to earliest Eocene. They exhibit low to moderate TOC contents, ranging from 0.4 to $1.0 \%$, with a mean value of $0.8 \%$. This mean value is considerably lower than the TOC content of samples below the seven elevated samples from $2798 \mathrm{~m}$ to $2763 \mathrm{~m}$.

Dylan Meadows, 2009. 
Chapter 6. Results

$\delta^{13} \mathrm{C}$

The four samples from $2908 \mathrm{~m}$ to $2808 \mathrm{~m}$ exhibit moderately light $\delta^{13} \mathrm{C}$ values ranging from -24.1 to $-23.5 \%$ o (0.6\% variation over $100 \mathrm{~m})$, with a mean $\delta^{13} \mathrm{C}$ of $-23.8 \%$. There are six consecutive samples from $2798 \mathrm{~m}$ to $2768 \mathrm{~m}$ that have recorded isotopically heavy $\delta^{13} \mathrm{C}$. The deepest of these samples, from $2798 \mathrm{~m}$, recorded a $\delta^{13} \mathrm{C}$ value of $-20.1 \%$. The following two samples from $2793 \mathrm{~m}$ and $2788 \mathrm{~m}$ become increasingly heavier with values of -19.5 and $-19.0 \%$ respectively. The sample from $2788 \mathrm{~m}\left(-19.0 \%\right.$ ) has the heaviest $\delta^{13} \mathrm{C}$ value in Clipper-1. The next two samples from $2783 \mathrm{~m}$ and $2778 \mathrm{~m}$ both contain heavy $\delta^{13} \mathrm{C}$, with recorded values of -19.2 and $-19.1 \%$. The shallowest of these six isotopically heavy samples from $2768 \mathrm{~m}$ has a $\delta^{13} \mathrm{C}$ value of $-20.6 \%$. The mean value for this heavy $\delta^{13} \mathrm{C}$ excursion interval is $-19.6 \%$, and there is $1.6 \%$ of variation over the $30 \mathrm{~m}$ sample interval. The shallowest seven samples contain light to moderately light $\delta^{13} \mathrm{C}$ values with the exception of the sample from $2713 \mathrm{~m}$, which has a relatively heavy $\delta^{13} \mathrm{C}$ of $-21.6 \%$. These seven samples range from -25.9 to $-21.6 \%$, with a mean value of $-24.3 \%$. This mean value is isotopically lighter than that of the average of the four samples that lie below the heavy $\delta^{13} \mathrm{C}$ excursion.

\section{Nitrogen content $(\% \mathrm{~N})$}

The deepest samples analysed, from $2908 \mathrm{~m}$ to $2818 \mathrm{~m}$, have nitrogen contents below $0.1 \%$. From $2808 \mathrm{~m}$ through $2763 \mathrm{~m}$, eight samples were analysed, all of which recorded high nitrogen values between 0.1 and $0.5 \%$. The highest recorded value of $0.5 \%$ came from $2788 \mathrm{~m}$, which also has the highest TOC content, and the heaviest $\delta^{13} \mathrm{C}$ values of all samples investigated in this well. This sample has the highest nitrogen content of all samples analysed in this study. Once again, all samples from this well that have high nitrogen contents have significantly higher TOC contents and isotopically heavier $\delta^{13} \mathrm{C}$ values than samples with low nitrogen contents. The six shallowest samples from $2753 \mathrm{~m}$ through $2633 \mathrm{~m}$ all recorded values below $0.1 \%$.

\section{Carbon/Nitrogen Ratio}

The thirteen samples from the deepest sample examined at $2908 \mathrm{~m}$ to the sample from $2728 \mathrm{~m}$ contain very similar $\mathrm{C} / \mathrm{N}$ ratios that range from 28 to 31 . The sample from $2713 \mathrm{~m}$ recorded the highest ratio, with a value of 37 . The sample from $2703 \mathrm{~m}$ has a ratio of 30 , followed by another high $\mathrm{C} / \mathrm{N}$ ratio in the sample from $2683 \mathrm{~m}(\mathrm{C} / \mathrm{N}=36)$. The shallowest 
Chapter 6. Results

sample, from $2633 \mathrm{~m}$, contains the lowest value of all samples examined in this well with a ratio of 20 . The average $\mathrm{C} / \mathrm{N}$ ratio of all seventeen samples analysed in Clipper- 1 is 30 .

\subsection{Discussion of TOC contents between wells across the Great South and Canterbury basins}

Total Organic Carbon (TOC) data provide a measure of how much organic matter is present in sediments. In this section, discussion will focus on the TOC changes throughout the sampled sections of each of the wells investigated and the most likely causes for such changes. Key concepts relating to the deposition and source of the Tartan Formation in the Great South and Canterbury basins combining all relevant geochemical data are discussed later in Chapter 7.

\section{Rakiura-1}

Samples investigated from Rakiura-1 generally display low organic richness ranging from 0.1 to $0.8 \%$ TOC. Unlike other wells studied here, and in most wells studied by Meadows (2008), there is no noticeable TOC increase in Late Paleocene to Early Eocene samples (approximately 1800-1750 m depth in this well as deduced from well logs in Placid Oil Co. 1984b), indicating that the Tartan Formation is absent from this well. Cook et al. (1999) describe this interval as having a sandier lithology and only locally carbonaceous. The gamma ray $\log$ response is not as marked as in other wells where the Tartan Formation is present and Schioler and Roncaglia (2008) do not recognise the Tartan Formation in this well. In fact, TOC contents are lower in the mid Paleocene than in the Early Paleocene, and this low organic content continues throughout the Late Paleocene until slightly higher organic contents are recorded from Early Eocene samples (Fig. 6.7; Rakiura-1).

Dylan Meadows, 2009. 

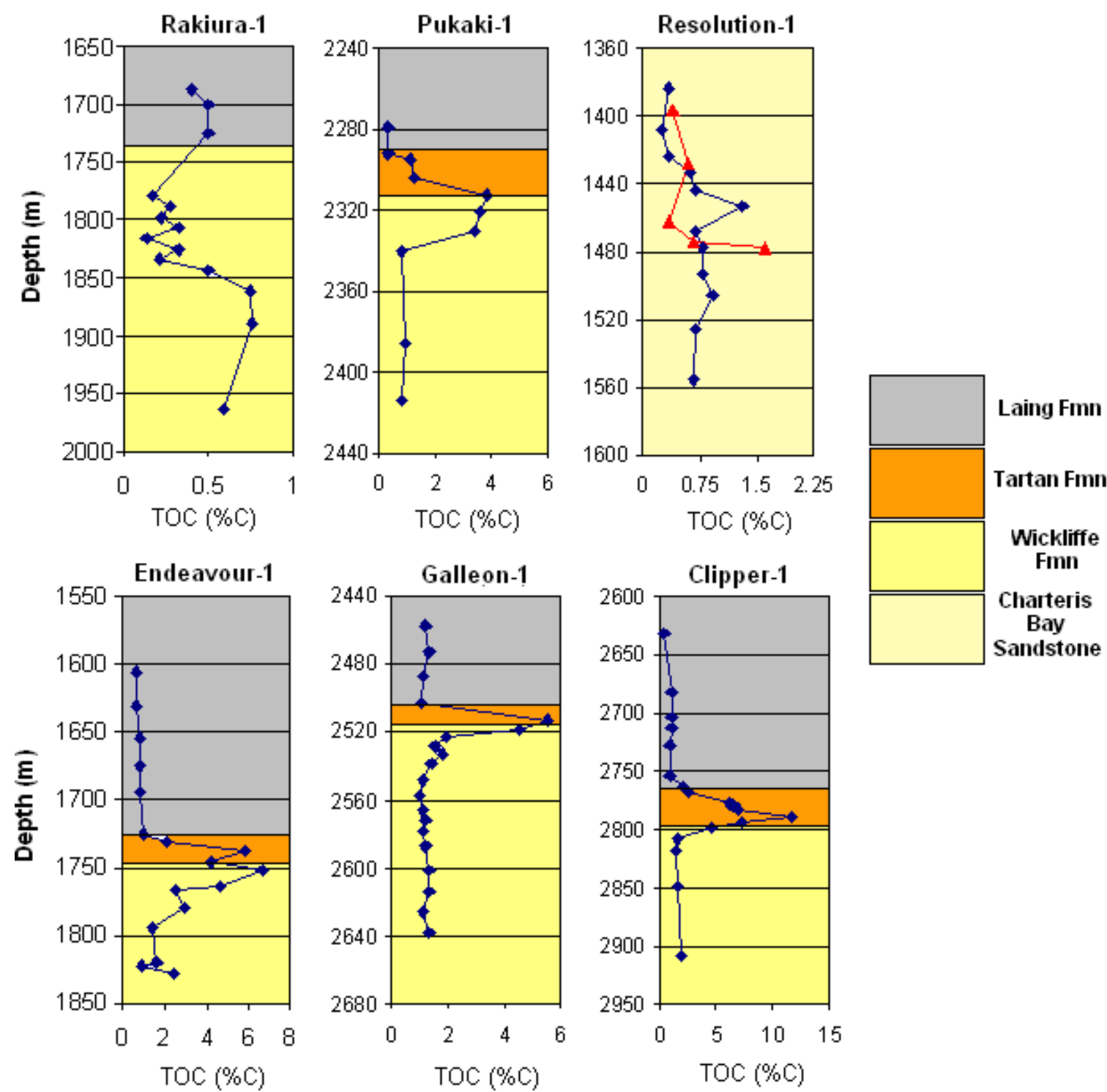

Figure 6.7 Well by well comparison of TOC content (note different depth and TOC scales).

\section{Pukaki-1}

Three cuttings samples from Pukaki-1 have high organic contents $(2330 \mathrm{~m}, 2321 \mathrm{~m}$, and $2313 \mathrm{~m}$ ). These have TOC contents of 3.4, 3.6, and 3.9\% respectively (Fig. 6.7; Pukaki-1). They are believed to belong to the Tartan Formation based on the gamma ray log response (see Section 7.1). Samples analysed from the overlying Laing and underlying Wickliffe formations have low to moderate TOC contents ranging from 0.3 to $1.3 \%$. It is thus evident that there was a profound change in the conditions under which the Tartan Formation 
Chapter 6. Results

accumulated and was preserved during deposition in this area of the Great South Basin with respect to the adjacent formations.

The relatively low organic richness of the Wickliffe and Laing formations is likely the result of low organic input and/or poor organic preservation of deposited organic matter. This gave way to good preservation of deposited organic matter, likely combined with increased organic input, during deposition of the Tartan Formation.

\section{Resolution-1}

Analysis of five sidewall cores and twelve cuttings samples from Resolution-1 yielded only two samples with TOC contents exceeding 1\%. The one sidewall core sample from $1478 \mathrm{~m}$ has the highest recorded TOC content of all samples in this well with an organic content of $1.6 \%$ TOC. This sample is believed to be from the earliest Paleocene, well below the Paleocene-Eocene boundary (approximately 1410-1435 m from GR logs). Samples examined around this Late Paleocene interval have low TOC contents ranging from 0.3 to $0.6 \%$. The only other sample from this well to exceed 1\% TOC came from a cuttings sample from 1453 $\mathrm{m}(1.3 \%$ TOC), and like the previously mentioned sidewall core sample, is from an early to mid Paleocene horizon. Late Cretaceous to Early Paleocene samples from Resolution-1 have slightly higher organic richness than those from the Late Paleocene to Early Eocene (Figure 6.7). This is the only well in this study where this trend is observed and it provides some evidence to suggest the absence of the Tartan Formation in Resolution-1. This trend also suggests that conditions for the preservation and accumulation of organic matter were slightly more favorable during the Early to mid Paleocene than they were during the Late Paleocene to Eocene in the Resolution-1 area of the Canterbury Basin.

\section{Endeavour-1}

Analysis of cuttings from Endeavour-1 between $1828 \mathrm{~m}$ and $1605 \mathrm{~m}$ yielded seven samples with high organic richness believed to represent the Tartan Formation. These seven samples, from $1779 \mathrm{~m}$ to $1731 \mathrm{~m}$, range in TOC content from 2.1 to $6.6 \%$ (Figure 6.7; Endeavour-1). Endeavour-1 displays a gradual increase in the TOC content from 3.0\% in the sample from $1779 \mathrm{~m}$ (the deepest sample to show an elevated organic content) through to the peak TOC content of $6.6 \%$ recorded in the sample from $1752 \mathrm{~m}$. A gradual decline in organic content is observed in the following Tartan Formation samples up to the shallowest elevated TOC 
Chapter 6. Results

sample from $1731 \mathrm{~m}(2.1 \%)$. It should be noted that the sample from $1746 \mathrm{~m}$ has a TOC value of $4.2 \%$ and is directly between two higher TOC samples $(6.6 \%$ below, and $5.9 \%$ above). This could be attributed to natural variation between samples (due to local depositional factors or even contamination of the cuttings in the well) or it could be evidence of a double pulse. Killops et al. $(1996,2000)$ have reported instances where a double pulse of organic richness in sedimentation is observed in outcrops of Waipawa Formation. In both Angora Stream (East Coast Basin) and Mead Stream (Inland Marlborough) the organic rich Waipawa Formation contains a unit of less organic rich, more calcareous sediment (Hollis et al. 2005). Killops et al. (1996, 2000) also report a similar double pulse in the Tartan Formation of Pakaha-1 and possibly Kawau-1A (Great South Basin), from results of TOC plotted against depth.

The TOC content of samples from below the Tartan Formation is, on average, higher than those from above it (1.6\% mean below, $0.8 \%$ mean above). This suggests that there was greater organic input and conditions for the preservation and accumulation of organic matter were greater prior to the deposition of the Tartan Formation than following it.

\section{Galleon-1}

A total of twenty cuttings samples were examined from Galleon-1 from $2638 \mathrm{~m}$ to $2458 \mathrm{~m}$ (Fig. 6.7; Galleon-1). Four of these samples displayed the high organic richness associated with the Tartan Formation (from $2533 \mathrm{~m}$ to $2513 \mathrm{~m}$ ), with the deepest, from $2533 \mathrm{~m}$, recording a TOC content of $1.8 \%$. This is considered to be a relatively low value for a sample from the Tartan Formation; however, on comparison with the heavy $\delta^{13} \mathrm{C}$ value recorded from this sample, it would appear to be characteristic of the Tartan Formation. The overlying sample from $2528 \mathrm{~m}$ does not appear to possess the characteristically high TOC content and heavy $\delta^{13} \mathrm{C}$ value associated with the Tartan Formation, as it has a relatively low TOC content of $1.5 \%$ (and an isotopically light $\delta^{13} \mathrm{C}$ value of $-25.5 \% 0$ ). It is possible that this low TOC sample represents the intervening organically poor layer between two organic rich layers of the unit as discussed above (Endeavour-1; TOC discussion). The next three samples from 2523, 2518, and $2513 \mathrm{~m}$ each contain high organic contents with TOC values of $2.0,4.5$, and $5.6 \%$ respectively.

Samples from underlying and overlying formations contain similar mean TOC values, suggesting that in this area of the Canterbury Basin conditions for the preservation and 
Chapter 6. Results

accumulation of organic matter were similar both prior and post Tartan Formation deposition. This situation is unique to this well, as other wells investigated in the present study and by Meadows (2008), where Tartan Formation is present, commonly show samples from underlying formations with greater organic richness than that of samples from above the Tartan Formation. This will be discussed further below.

\section{Clipper-1}

In Clipper-1, six of the seventeen samples analysed from $2908 \mathrm{~m}$ to $2633 \mathrm{~m}$ recorded high organic richness that is consistent with Tartan Formation (Fig. 6.7; Clipper-1). The deepest of these, from $2798 \mathrm{~m}$, has a TOC content of 4.6\%, and a gradual rise in organic content occurs over the following two samples from $2793 \mathrm{~m}$ and $2788 \mathrm{~m}$ with values of 7.1 and $11.7 \%$ respectively. The sample from $2788 \mathrm{~m}(11.7 \%)$ has the highest TOC content of all samples examined here. Over the following four samples, from $2783 \mathrm{~m}$ to $2763 \mathrm{~m}$, there is a gradual decrease in the organic richness from $11.7 \%$ at $2788 \mathrm{~m}$ to $2.0 \%$ at $2763 \mathrm{~m}$. The pattern for Clipper-1 Tartan Formation samples (Fig. 6.7; Clipper-1) suggests that environmental perturbations associated with deposition of the formation were less pronounced during the initial and final stages of deposition, but were at their peak during the mid stages of deposition, coinciding with the higher TOC values of $7.1,11.7$, and $6.8 \%$ at 2793, 2788, and $2783 \mathrm{~m}$ respectively. Figure 6.7 (Clipper-1) shows that samples below the Tartan Formation contain, on average, higher TOC contents than that of those samples above the Tartan Formation.

\subsection{Nitrogen contents of samples from wells from the Great South and Canterbury basins}

For the purposes of this study, the nitrogen contents were primarily recorded and used in conjunction with the TOC data to calculate the $\mathrm{C} / \mathrm{N}$ ratio for each sample. The nitrogen content data are not discussed individually; instead, Section 6.9 details the importance of these data when combined with TOC data. The nitrogen contents of all samples examined in this study are presented in Appendix 4. 
Chapter 6. Results

\subsection{Discussion of $\mathrm{C} / \mathrm{N}$ between wells across the Great South and Canterbury basins}

$\mathrm{C} / \mathrm{N}$ ratios can be used to distinguish between marine and terrestrial origins in sedimentary organic matter (Meyers, 1994). Fresh, unaltered algae typically have atomic C/N ratios between 5 and 8 (Emerson and Hedges, 1988; Meyers, 1994), whereas vascular land plants have $\mathrm{C} / \mathrm{N}$ ratios of $\geq 20$ (Meyers, 1994). This distinction is caused by the absence of cellulose in algae and its abundance vascular plants (Meyers, 1994), and also the protein richness of algal organic matter (Rau et al. 1987; Twichell et al. 2002). Meyers (1994) has stated that $\mathrm{C} / \mathrm{N}$ ratio variability can also result from changes in the proportions of $\mathrm{C}_{3}$ and $\mathrm{C}_{4}$ plant material.

Meyers (1992) suggested that elevated $\mathrm{C} / \mathrm{N}$ ratios may be associated with high rates of marine productivity, possibly under conditions of low nitrogen availability, and this has been observed in modern sediments (Meyers et al. 2006). The organic matter produced under these conditions would be lipid-rich and nitrogen-poor. Organic-rich strata may have elevated $\mathrm{C} / \mathrm{N}$ ratios as a result of selective loss of nitrogenous organic compounds (Rau et al. 1987). Verardo and MacIntyre (1994) have proposed that high $\mathrm{C} / \mathrm{N}$ ratios can indicate faster loss of nitrogen over carbon during the sinking of marine organic matter from the photic zone. They reasoned that nitrogen-containing proteinaceous matter is more readily utilised by microbes than carbohydrate compounds. Meyers (1997) made a similar point in that partial degradation of algal organic matter during sinking can selectively reduce proteinaceous compounds, thus raising the $\mathrm{C} / \mathrm{N}$ ratio. Van Mooy et al. (2002) stated that degradation of organic matter is different under oxic and suboxic conditions. They concluded that suboxic microbial degradation by denitrification preferentially utilises nitrogen-rich amino acids, leaving a larger portion of the nitrogen-poor organic components intact than under an oxic environment, and thus the $\mathrm{C} / \mathrm{N}$ ratios of the surviving organic matter are higher.

Selective degradation of organic matter components during early diagenesis can also modify $\mathrm{C} / \mathrm{N}$ ratios of organic matter in sediments (Meyers, 1997). The $\mathrm{C} / \mathrm{N}$ source signature of sub-aqueous sediments is generally well preserved despite the large reduction of the total amount of organic matter during sinking. Both $\mathrm{C} / \mathrm{N}$ and $\delta{ }^{13} \mathrm{C}$ values appear to experience little diagenetic change through time once deposited on the seafloor (Meyers, 1994; Twichell 
Chapter 6. Results

et al. 2002), and thus the source information gathered from $\mathrm{C} / \mathrm{N}$ ratios in sub-aqueous sediments is generally reliable (Meyers, 1997).

Meyers et al. (2006) stated that elevated C/N ratios are typical of black shales, and indicate depressed organic matter degradation associated with suboxic conditions in the water column, which preferentially favors preservation of carbon-rich forms of marine organic matter over nitrogen-rich components. Meyers et al. (2006) also mentioned that $\mathrm{C} / \mathrm{N}$ values between 20 and 40 in black shales are unusual for marine organic matter but are common in mid-Cretaceous black shales (Rau et al. 1987; Meyers, 1989; Dumitrescu and Brassell, 2006).

There are circumstances where the $\mathrm{C} / \mathrm{N}$ ratios impart misleading indications of bulk organic matter origins. The majority of sediments contain low inorganic nitrogen (IN) concentrations compared to the organic nitrogen content and thus $\mathrm{C} / \mathrm{N}$ ratios usually represent organic matter concentration closely. However, in some sediments that contain low organic matter concentrations, where the TOC content is less than $0.3 \%$, the proportion of inorganic nitrogen can occasionally constitute a large fraction of the residual nitrogen, and so $\mathrm{C} / \mathrm{N}$ ratios based on residual nitrogen could be artificially low (Meyers, 1997). Rau et al. (1987) made a similar point, and further suggested that $\mathrm{C} / \mathrm{N}$ ratios may also be depressed because of significant adsorbed inorganic nitrogen from bacterial degradation of organic material. Rogers (pers. comm, 2008) considered that $\mathrm{C} / \mathrm{N}$ ratios in samples with low organic contents (below 0.3\%) become more difficult to accurately detect using present analytical methods, and hence analytical errors become larger. These views are taken into consideration in the $\mathrm{C} / \mathrm{N}$ discussion in Chapter 7 .

The $\mathrm{C} / \mathrm{N}$ ratios calculated from the TOC and nitrogen contents in this study are of particular importance. Previous studies of the Tartan/Waipawa Formation by Killops et al. (1996) and Killops et al. (2000) have stated that the formation had a predominantly marine origin with variable terrestrial components incorporated. Terrestrial components are present in many samples examined from the Waipawa Formation in the East Coast Basin, and traces of black, coaly material are also present in samples examined from the Great South Basin from Kawau-1A, Pakaha-1 and Toroa-1 (Killops et al. 2000).

Of the four wells studied here that appear to contain Tartan Formation, no sample from within the Tartan Formation interval has a C/N ratio below 20 (Fig. 6.8). 

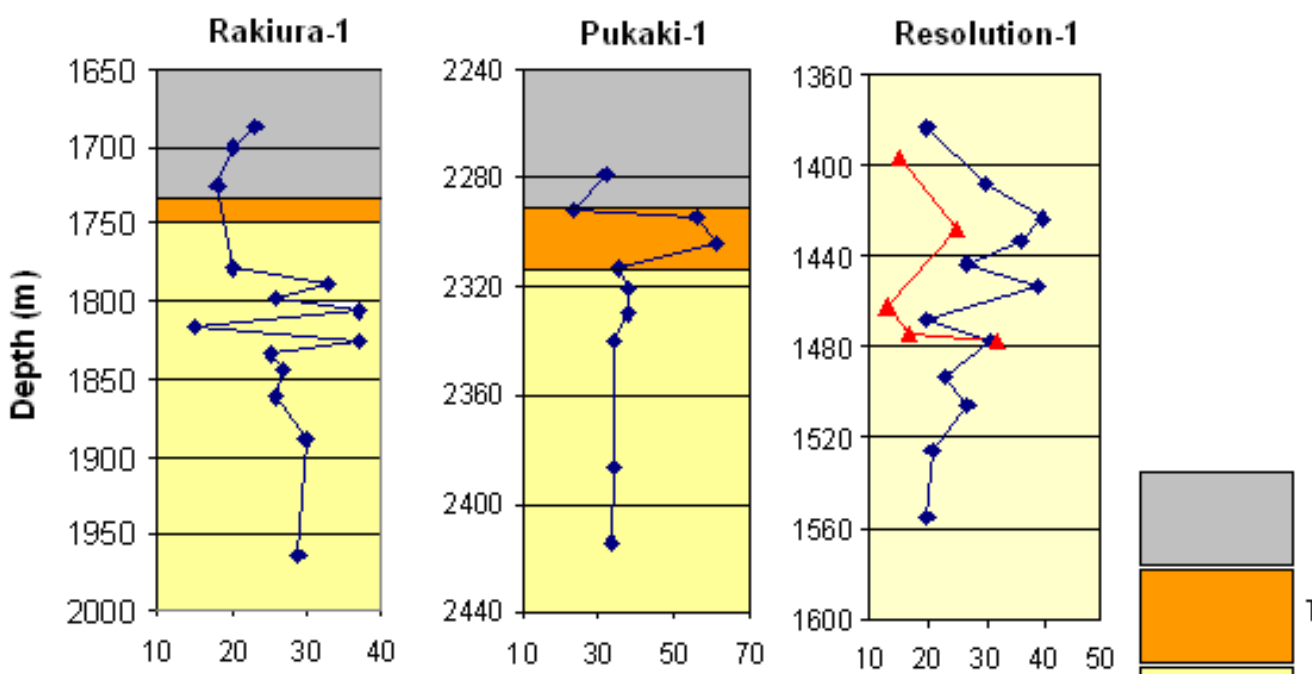

Laing Fmn

Tartan Fmn
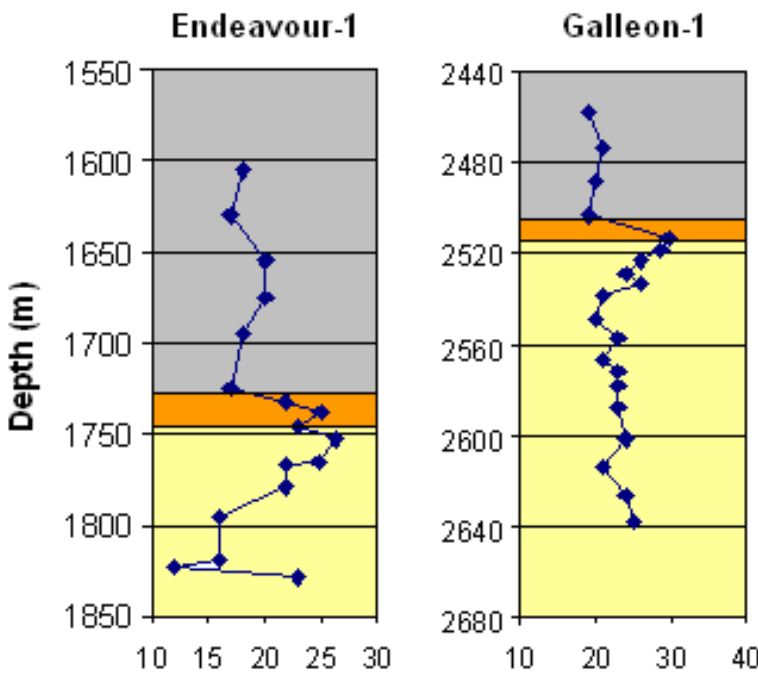

Clipper-1

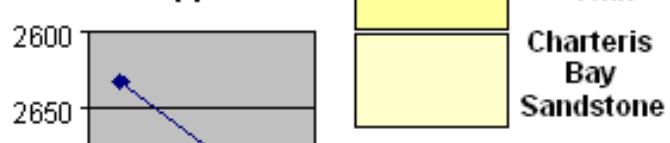

Wickliffe

Fmn

Charteris

Sandstone
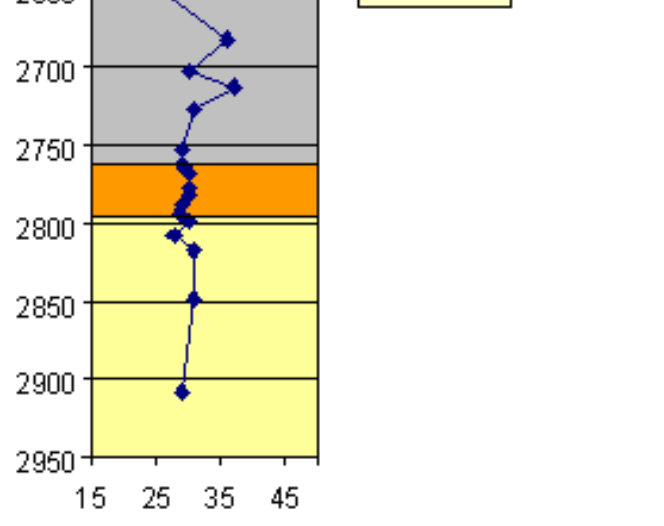

Cuttings. Sidewall Core

Figure 6.8 Well by well comparison of $\mathrm{C} / \mathrm{N}$ ratio (note different depth and $\mathrm{C} / \mathrm{N}$ scales).

As discussed above, typical unaltered algal organic matter has low $\mathrm{C} / \mathrm{N}$ ratios between 5 and 8 , and $\mathrm{C} / \mathrm{N}$ ratios of 20 or greater are associated with vascular land plants, whereas ratios between 10 and 20 are considered to have been derived from a mixed marine and terrestrial source. The approximately twenty samples from four wells with Tartan Formation present have $\mathrm{C} / \mathrm{N}$ ratios between 22 and 38 .

$\mathrm{C} / \mathrm{N}$ results presented in Figure 6.8 of samples within the Tartan Formation interval indicate that the organic matter is derived from a predominantly terrestrial source, with possibly some marine contribution that has elevated $\mathrm{C} / \mathrm{N}$ ratios as a result of preferential nitrogen loss during biological degeneration. Overall, 79 of 90 cuttings and 2 of 5 sidewall

Dylan Meadows, 2009. 
Chapter 6. Results

core samples have $\mathrm{C} / \mathrm{N}$ ratios of 20 or greater, and all 95 samples examined have ratios exceeding 10 (Appendix 4).

\section{Rakiura-1}

In Rakiura-1, where the Tartan Formation does not appear to be present, $\mathrm{C} / \mathrm{N}$ ratios range from 15 to 37 , with a mean value of 26 , indicating that some samples contain a mixed marine and terrestrial origin and others contain organic matter derived from a predominantly terrestrial source but that overall the organic matter is primarily derived from a terrestrial vascular plant type.

\section{Pukaki-1}

The three Tartan Formation samples analysed from Pukaki-1, from 2330 m to $2313 \mathrm{~m}$, each recorded similar $\mathrm{C} / \mathrm{N}$ ratios ranging from 36 to 38 , indicating a constant source of organic matter that was likely derived from predominantly terrestrial plants. The two samples from $2304 \mathrm{~m}$ and $2295 \mathrm{~m}$ have exceptionally high $\mathrm{C} / \mathrm{N}$ ratios of 61 and 56 respectively. These values could be the result of a very high terrestrial composition, and selective nitrogen loss within the organic matter during sediment deposition by microbial reworking. Remaining samples from above and below the Tartan Formation interval have $\mathrm{C} / \mathrm{N}$ ratios ranging from 23 to 34 , which suggests that there is a high proportion of terrestrial organic matter contained within these samples; however, the terrestrial organic matter contained within these samples differs from the terrestrial organic matter contained within the Tartan Formation samples, as shown by the $\mathrm{C} / \mathrm{N}$ ratio differences.

\section{Resolution-1}

Sidewall core analyses from Resolution-1, between $1478 \mathrm{~m}$ and $1396.5 \mathrm{~m}$, indicate a mixed marine and terrestrial organic matter origin for three of the five samples $(\mathrm{C} / \mathrm{N}$ ratios range from 13 to 17), and two samples which exhibit a primarily terrestrial character (ratios of 25 and 32). Cuttings sampling of Resolution-1 between $1555 \mathrm{~m}$ and $1383 \mathrm{~m}$ recorded C/N ratios between 20 and 40, with a mean ratio of 28 . This indicates that the organic matter contained within samples over this sampling range was primarily derived from a terrestrial source. No Tartan Formation appears to be present in Resolution-1 from analyses of both sidewall core and cuttings samples. Upon examination of Figure 6.8 (Resolution-1) it is 
Chapter 6. Results

apparent that sidewall core and cuttings samples give relatively similar trends for $\mathrm{C} / \mathrm{N}$ ratios; however, the sidewall core samples appear to contain, on average, slightly lower $\mathrm{C} / \mathrm{N}$ ratios. The slight ratio differences between sidewall cores and cuttings may indicate that the marine component is better preserved in the sidewall core samples than it is in cuttings samples, which may be contaminated by cavings, where samples from higher depths are incorporated into samples received from deeper in the borehole.

\section{Endeavour-1}

Sampling of cuttings from Endeavour-1 recorded C/N ratios that range between 12 and 26, with a mean of 20 (Fig. 6.8; Endeavour-1). Seven of the seventeen samples examined from $1828 \mathrm{~m}$ to $1605 \mathrm{~m}$ lie within the Tartan Formation interval (samples $1779 \mathrm{~m}$ through $1731 \mathrm{~m}$ ) and have $\mathrm{C} / \mathrm{N}$ ratios between 22 and 26 (mean $=24$ ). It appears that the formations that immediately enclose the Tartan Formation contain mixed marine and terrestrial organic matter, with relatively low $\mathrm{C} / \mathrm{N}$ ratios, whereas those samples within the Tartan Formation with high $\mathrm{C} / \mathrm{N}$ ratios have a greater terrestrial organic matter component.

\section{Galleon-1}

Of the twenty samples examined from Galleon-1 between $2638 \mathrm{~m}$ and $2458 \mathrm{~m}$, four have the geochemical characteristics associated with the Tartan Formation (from 2533 m to 2513 $\mathrm{m}) . \mathrm{C} / \mathrm{N}$ ratios are high in these four samples, ranging from 26 to 30 (mean $=28$ ). This is considerably higher than for samples from above and below the Tartan Formation interval and for the overall $\mathrm{C} / \mathrm{N}$ mean for all Galleon-1 samples (23). This suggests that the Tartan Formation was under a greater terrestrial influence than adjacent formations. The $\mathrm{C} / \mathrm{N}$ ratio appears to decrease with decreasing depth (excluding the four Tartan Formation samples Figure 6.8 [Galleon-1]). This may indicate that a more marine influence developed during the course of deposition from 2638 m to 2458 m (Early Paleocene to mid-Late Paleocene).

\section{Clipper-1}

Analyses of seventeen cuttings samples from Clipper-1 showed six to lie within the Tartan Formation interval boundaries as recognised by gamma ray log response (see Section 7.1). These are from $2798 \mathrm{~m}$ to $2768 \mathrm{~m}$ and have $\mathrm{C} / \mathrm{N}$ ratios ranging from 29 to 30, indicating a primarily terrestrial organic matter source. This consistent $\mathrm{C} / \mathrm{N}$ range over the $30 \mathrm{~m}$ of 
Chapter 6. Results

Tartan Formation samples suggests that the conditions under which the Tartan Formation was preserved was consistent throughout deposition. Samples lying outside the Tartan Formation interval have $\mathrm{C} / \mathrm{N}$ ratios that range from 20 to 37 , with a mean ratio of 30 . The most likely origin of the organic matter in this sample set is again terrestrial.

\subsection{Discussion of $\delta^{13} \mathrm{C}$ between wells across the Great South and Canterbury basins}

Carbon isotopic ratios are useful for distinguishing between marine and continental plant sources of organic matter and for identifying different types of land plant contributions in marine sediments (Meyers, 1994, 1997).

Biochemical fractionation of carbon isotopes is primarily a kinetic process (White, 2001) and occurs during photosynthesis (Meyers, 1994). In marine plants such as phytoplankton, carbon isotopic fractionation is controlled by many factors such as temperature, availability of $\mathrm{CO}_{2}$ (aqueous), light intensity, nutrient availability and $\mathrm{pH}$, as well as physiological factors such as cell size and growth rate (Hoefs, 2004). Most photosynthetic plants incorporate carbon into organic matter using the $\mathrm{C}_{3}$ Calvin-Benson metabolic pathway, which biochemically discriminates against ${ }^{13} \mathrm{C}$ to produce a $\delta^{13} \mathrm{C}$ shift of approximately $-20 \%$ from the isotopic ratio of the inorganic carbon source (Meyers, 1994). Approximately $90 \%$ of modern plants utilise the Calvin-Benson metabolic pathway, producing $\mathrm{C}_{3}$ plants. These include most trees and shrubs, algae and autotrophic bacteria and most cultivated vegetation. Isotopic ranges for organic matter of $\mathrm{C}_{3}$ type marine plants are approximately $-20 \%$ for bacterial carboxylation and $-29 \%$ for higher plant species (White, 2001). Organic matter produced from atmospheric $\mathrm{CO}_{2}\left(\delta^{13} \mathrm{C} \sim-7 \%\right.$ ) by land plants using the $\mathrm{C}_{3}$ pathway consequently has average $\delta^{13} \mathrm{C}$ values between -29 and -26\% PDB (Meyers, 1994).

Some plant species incorporate carbon into organic matter using the $\mathrm{C}_{4}$ Hatch-Slack pathway, which creates less carbon isotopic fractionation and gives heavier $\delta^{13} \mathrm{C}$ values (White, 2001). Meyers (1994) stated that organic matter derived from $\mathrm{C}_{4}$ type plants has $\delta^{13} \mathrm{C}$ values around $-14 \%$. Modern $\mathrm{C}_{4}$ plant types include many grasses, corn and sugarcane (White, 2001).

Hayes (1993) concluded that the ${ }^{13} \mathrm{C}$ content of each biomolecule depends primarily on four factors: (1) the ${ }^{13} \mathrm{C}$ content of the carbon source, (2) isotopic effects associated with the assimilation of carbon, (3) isotopic effects associated with metabolism and biosynthesis (i.e. during respiration and uptake of $\mathrm{CO}_{2}$ ), and (4) cellular carbon budgets at each branch point 
(at each point within the cellular reaction network, distribution of carbon among products will affect isotopic compositions). White (2001) suggested that $\delta^{13} \mathrm{C}$ compositions become slightly heavier moving up the food chain. The carbon isotopic compositions of organic matter reflect principally the dynamics of carbon assimilation during photosynthesis and the isotopic composition of the source (Hayes, 1993).

Marine algae (all $\mathrm{C}_{3}$ type plants; White, 2001) and bacteria are isotopically heavier than $\mathrm{C}_{3}$ land plants (Meyers, 1994), as the main chemical compounds (lipids and carbohydrates) in terrestrial plants are usually isotopically lighter than those of marine plants (Tissot and Welte, 1978). Hayes (1993) stated that lipids contain less heavy ${ }^{13} \mathrm{C}$ than other products of biosynthesis and hence are isotopically lighter. The distinction between marine and terrestrial organic matter reflects the isotopic composition of the carbon source for photosynthesis; marine plants utilise dissolved carbonate components in seawater, whereas terrestrial plants use atmospheric $\mathrm{CO}_{2}$, with an isotopically lighter $\delta^{13} \mathrm{C}$ ratio (Tissot and Welte, 1978). Freshwater algae utilise dissolved $\mathrm{CO}_{2}$, which is usually in isotopic equilibrium with atmospheric $\mathrm{CO}_{2}$. The source of inorganic carbon for marine algae is dissolved bicarbonate, which, with a $\delta^{13} \mathrm{C}$ value of approximately 0\%o (Meyers, 1994), is heavier than atmospheric $\mathrm{CO}_{2}\left(\delta^{13} \mathrm{C} \sim-7 \%\right.$ ). Thus marine organic matter is generally isotopically heavier than terrestrial organic matter.

Late Cretaceous black shales are commonly isotopically lighter than Cenozoic organic-rich marine sediments. Dean et al. (1986) concluded from carbon isotopic studies that the isotopic differences between Cretaceous black shales (-29 to -26\%0) and Neogene organicrich sediments $\left(-23\right.$ to $-16 \%$ ) were the result of dissolved $\mathrm{CO}_{2}$ availability to marine algae. They reported that $\mathrm{CO}_{2}$ availability during the Late Cretaceous was higher than in the Neogene, thus resulting in isotopically lighter $\delta^{13} \mathrm{C}$ ratios in Cretaceous black shales.

Carbon isotope results from this study will be discussed initially as a well by well description of results and later, in Chapter 7, will integrate all relevant geochemical data to provide an overall interpretation of possible sources and conditions surrounding the deposition of the organic matter present in the Tartan Formation. Further correlation and comparison are also discussed in Chapter 7 where geochemical data from the present study are integrated with the findings from Meadows (2008). 
Chapter 6. Results

\section{Rakiura-1}

$\delta^{13} \mathrm{C}$ results from Rakiura-1 (Fig. 6.9; Rakiura-1) display a narrow range in light isotopic values (from -27.2 to $-25.7 \%$ ). As there is such little variation in $\delta^{13} \mathrm{C}$ over the $276 \mathrm{~m}$ sampling range, it is likely that there was a consistent source of deposited organic matter throughout the sampled section of this well. The isotopically light nature of samples from in this well suggests that the organic matter contains a significant proportion of terrestrial plant material, which was most likely derived from plants that utilised the $\mathrm{C}_{3}$ Calvin-Benson metabolic pathway.
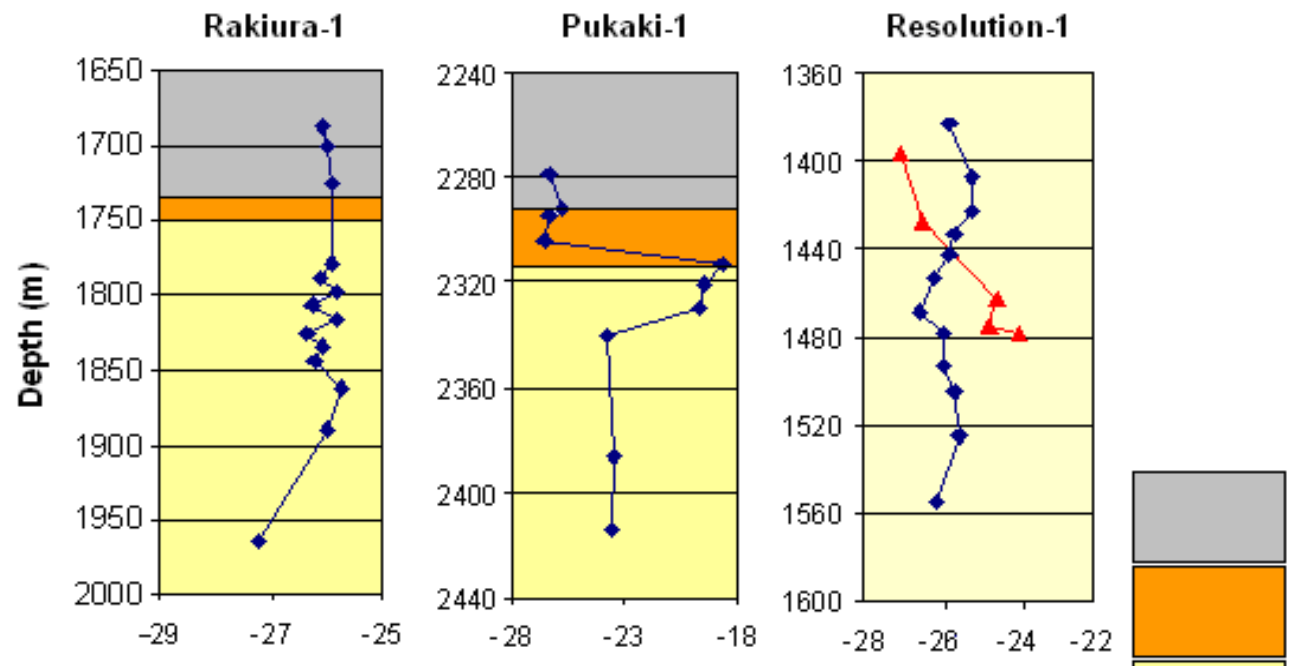

Laing Fmn
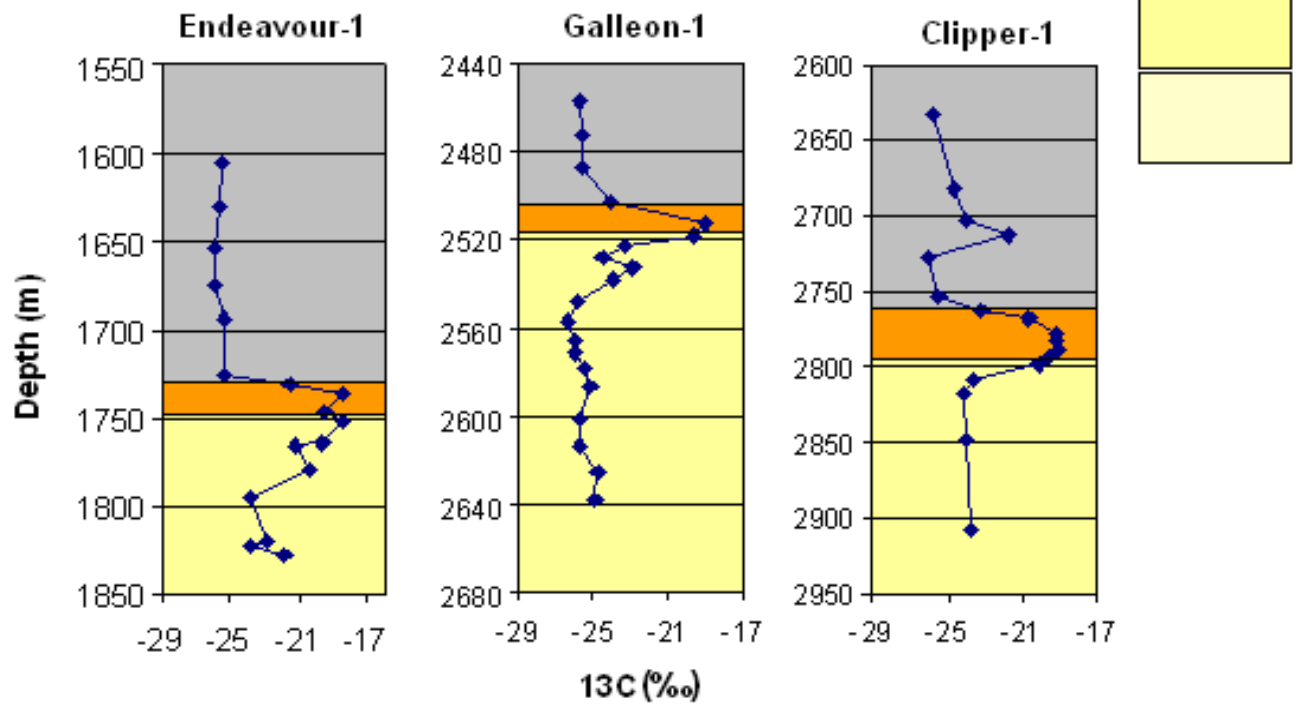

Tartan Fmn

Wickliffe

Fmn

Charteris

Bay

Sandstone

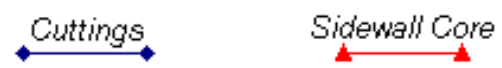

Figure 6.9 Well by well comparison of $\delta^{13} \mathrm{C}$ (note different depth and $\delta^{13} \mathrm{C}$ scales).

Dylan Meadows, 2009. 
Chapter 6. Results

\section{Pukaki-1}

Ten samples from Pukaki-1, from $2414 \mathrm{~m}$ to $2279 \mathrm{~m}$, were analysed and a positive isotopic excursion was recorded over the three samples from 2330 m, $2321 \mathrm{~m}$, and $2313 \mathrm{~m}$ (Fig. 6.9; Pukaki-1). These three samples have $\delta^{13} \mathrm{C}$ values ranging from -19.7 to $-18.7 \%$. Figure 1 from Meyers (1994) shows that $\mathrm{C}_{3}$ marine algae and $\mathrm{C}_{3}$ land plants can record values around $-20 \%$; however, $\mathrm{C}_{3}$ terrestrial plants average approximately $-27 \%$. To get the heaviest value of $-18.7 \%$ recorded in the sample from $2313 \mathrm{~m}$ it is possible that there was a significant contribution from marine plant and bacterial material, possibly with $\mathrm{C}_{3}$ land plants. Possible origins of the organic matter contained within these samples will be discussed in greater detail in Chapter 7.

The three samples analysed from below the Tartan Formation positive excursion in Pukaki-1 have an isotopic range from -23.8 to $-23.5 \%$. This isotopic range is indicative of $\mathrm{C}_{3}$ marine plants, marine bacteria and algae, and/or $C_{3}$ terrestrial plants. Above the Tartan Formation excursion, from $2304 \mathrm{~m}$ to $2279 \mathrm{~m}$, the $\delta^{13} \mathrm{C}$ range is lighter than that of samples below the Tartan Formation excursion, ranging from -26.6 to $-25.8 \%$. It is likely that the organic matter contained within these samples is derived from a predominantly $\mathrm{C}_{3}$ land plant source. The approximately $2.5 \%$ lighter $\delta^{13} \mathrm{C}$ difference in samples from above the Tartan Formation interval indicates that there is a higher concentration of $\mathrm{C}_{3}$ terrestrial plants in these samples compared to the isotopically heavier samples below the Tartan Formation excursion.

\section{Resolution-1}

$\delta^{13} \mathrm{C}$ analyses of five sidewall core samples from Resolution-1 between $1478 \mathrm{~m}$ and 1396.5 $\mathrm{m}$ recorded isotopically light values that range from -27.0 to $-23.9 \%$. It is likely that organic matter contained within these samples was derived from a predominantly $\mathrm{C}_{3}$ terrestrial source. The deepest sample examined from $1478 \mathrm{~m}$, which recorded a moderately heavy $\delta^{13} \mathrm{C}$ value of $-23.9 \%$ may have a mixed $\mathrm{C}_{3}$ marine and $\mathrm{C}_{3}$ land plant source.

Analyses of twelve cuttings samples from Resolution-1, from $1555 \mathrm{~m}$ to $1383 \mathrm{~m}$, recorded a narrow $\delta^{13} \mathrm{C}$ isotopic range from -26.6 to $-25.1 \%$. These isotopically light $\delta^{13} \mathrm{C}$ values are indicative of predominantly $\mathrm{C}_{3}$ land plant-derived organic matter. The relatively small variations throughout the sample set suggest a constant source of organic matter throughout 
Chapter 6. Results

deposition. The cuttings samples overlap the $\delta^{13} \mathrm{C}$ range of the Resolution-1 sidewall core samples from similar depths; however, the sidewall cores, on average, have slightly heavier $\delta^{13} \mathrm{C}$ values than the cutting samples (Fig. 6.9; Resolution-1).

\section{Endeavour-1}

Seven of the seventeen cuttings samples analysed from Endeavour-1 between $1828 \mathrm{~m}$ and $1605 \mathrm{~m}$ were from the Tartan Formation interval (between $1779 \mathrm{~m}$ and $1731 \mathrm{~m}$ ). Each of these seven gave isotopically heavy $\delta^{13} \mathrm{C}$ values ranging from -21.5 to $-18.5 \%$ (Fig. 6.9; Endeavour-1). The organic matter contained in samples from the Tartan Formation in this well was most likely derived from $\mathrm{C}_{3}$ marine plants and bacteria with some $\mathrm{C}_{3}$ land plant contribution. The four samples examined from below the Tartan Formation, from $1828 \mathrm{~m}$ to $1795 \mathrm{~m}$, have relatively heavy $\delta^{13} \mathrm{C}$ values ranging from -23.9 to $-21.9 \%$. These are much heavier than the mean $\delta^{13} \mathrm{C}$ values of the six samples from above the Tartan Formation interval (from 1725 to $1605 \mathrm{~m}$ ), which have a light isotopic character ranging from -26.0 to $25.3 \%$ (mean $=-25.6 \%$ ). It is evident that environmental conditions and/or source material deposition were different before and after Tartan Formation deposition (Figure 6.9; Endeavour-1). These differences could be caused by differences in the relative proportions of marine and terrestrial components incorporated into the deposited organic matter. The organic matter contained in these samples is likely to be a mixture of marine and terrestrial $\mathrm{C}_{3}$ plant material. The lighter $\delta^{13} \mathrm{C}$ samples from above the Tartan Formation interval most probably have a higher proportion of $\mathrm{C}_{3}$ land plant material than that of the samples below the Tartan Formation, accounting for the lighter $\delta^{13} \mathrm{C}$ character observed.

\section{Galleon-1}

Twenty cuttings samples were examined from Galleon-1, between $2638 \mathrm{~m}$ and $2458 \mathrm{~m}$ (Fig. 6.9; Galleon-1). Of these samples, four are thought to represent the Tartan Formation (from 2533, 2523, 2518, and $2513 \mathrm{~m}$ ). The latter have a $\delta^{13} \mathrm{C}$ range from -23.3 to $-19.0 \%$, with a mean value of $-21.2 \%$, and probably contain organic matter derived from a mixture of $\mathrm{C}_{3}$ terrestrial plant and $\mathrm{C}_{3}$ marine plant sources. The eleven samples from below the Tartan Formation interval have all recorded relatively light $\delta^{13} \mathrm{C}$ values ranging from -26.4 to $-24.0 \%$, with a mean of $-25.2 \%$. Samples above the Tartan Formation interval have very similar $\delta^{13} \mathrm{C}$ parameters, ranging from -25.7 to $-24.1 \%$, with a mean of $-25.2 \%$. It is possible 
Chapter 6. Results

that around this area of the Canterbury Basin the source of organic matter was similar both prior and post Tartan Formation deposition. The relatively light isotopic nature of these samples suggests that the organic matter source was predominantly $\mathrm{C}_{3}$ terrestrial plants, with some small $\mathrm{C}_{3}$ marine plant contributions in the heavier non-Tartan Formation samples.

\section{Clipper-1}

Six of the seventeen samples analysed between $2908 \mathrm{~m}$ and $2633 \mathrm{~m}$ from Clipper-1 lie within the Tartan Formation interval. These six samples, from $2798 \mathrm{~m}$ to $2768 \mathrm{~m}$, have recorded heavy $\delta^{13} \mathrm{C}$ values which range from -20.6 to $-19.0 \%$, with a mean of $-19.6 \%$. The organic matter here is most likely to have been derived from a mixture of sources. Organic matter with $\delta^{13} \mathrm{C}$ values of around $-20 \%$ could have been sourced from $\mathrm{C}_{3}$ marine plants that were derived from bacterial carboxylation, and marine algae, and possibly some $\mathrm{C}_{3}$ land plant contribution. There are two samples from $2808 \mathrm{~m}$ and $2763 \mathrm{~m}$, from above and below the Tartan Formation interval respectively, which have intermediate $\delta^{13} \mathrm{C}$ values of $-23.5 \%$ o and $-23.2 \%$. Close inspection of Figure 6.9 (Clipper-1) suggests that these two samples possibly represent the initial and final stages of Tartan Formation deposition. If this is the case, then an explanation for the slightly lighter $\delta^{13} \mathrm{C}$ character of these samples, compared to the heavy Tartan Formation samples, could be a gradual onset of and decline from the environmental changes that built up to the Tartan Formation deposition in this area of the basin. The three remaining samples below the Tartan Formation contain intermediate $\delta^{13} \mathrm{C}$ values, with a mean of $-23.9 \%$. These samples are on average heavier than those samples above the Tartan Formation interval, which recorded a mean $\delta^{13} \mathrm{C}$ of $-24.5 \%$. It is probable that the organic matter present in these samples was derived from a mixed marine and terrestrial source. The sample from $2713 \mathrm{~m}$ had an anomalously heavy $\delta^{13} \mathrm{C}$ value of $-21.6 \%$. This is well above the recognised Tartan Formation interval, and its heavy $\delta^{13} \mathrm{C}$ character could be the result of a brief period of increased marine contribution to the organic matter; however, the high $\mathrm{C} / \mathrm{N}$ ratio of 37 indicates a predominantly terrestrial origin, complicating the origin of its organic mater. The samples taken directly above and below this sample, from $2728 \mathrm{~m}$ and $2703 \mathrm{~m}$ have much lighter values of -25.9 and $-23.9 \%$ respectively, consistent with values from enclosing formations of the Tartan Formation recorded in other wells. 
Chapter 7. Discussion

\section{CHAPTER 7}

\section{Discussion}

Discussion here of geochemical data from exploration wells investigated is based upon correlation to gamma ray (GR) logs (defining the lithological interval of the Tartan Formation), as these show differences between lithologic and geochemical boundaries over the intervals studied. Possible sources of organic matter are also discussed, as are the causes and timing of Tartan Formation deposition, and correlation to the Waipawa Formation. Data obtained during the present study are integrated with results from the study by Meadows (2008).

\subsection{Geochemical correlation to Gamma Ray logs}

GR logs covering the sampled interval, including the Tartan Formation interval, were derived from the original logs that are included in the relevant well completion and petroleum reports.

GR logs are lithology logs that measure the natural radiation of a formation. Sandstones and carbonates have low concentrations of radioactive material, and thus emit low levels of gamma radiation. Shales characteristically concentrate more radioactive material, thus emitting higher levels of gamma radiation than coarser sediments. Thus, as the shale content of a formation increases so to does the GR response (Asquith, 1983).

In the present study two wells from the Great South Basin (Rakiura-1 and Pukaki-1), and four wells from the Canterbury Basin (Resolution-1, Endeavour-1, Galleon-1, and Clipper-1) have been investigated. Four of these six wells contained Tartan Formation: Pukaki-1, Endeavour-1, Galleon-1, and Clipper-1. The GR logs for each of the wells are plotted against the geochemical data in Figure 7.1.

Dylan Meadows, 2009. 
Chapter 7. Discussion

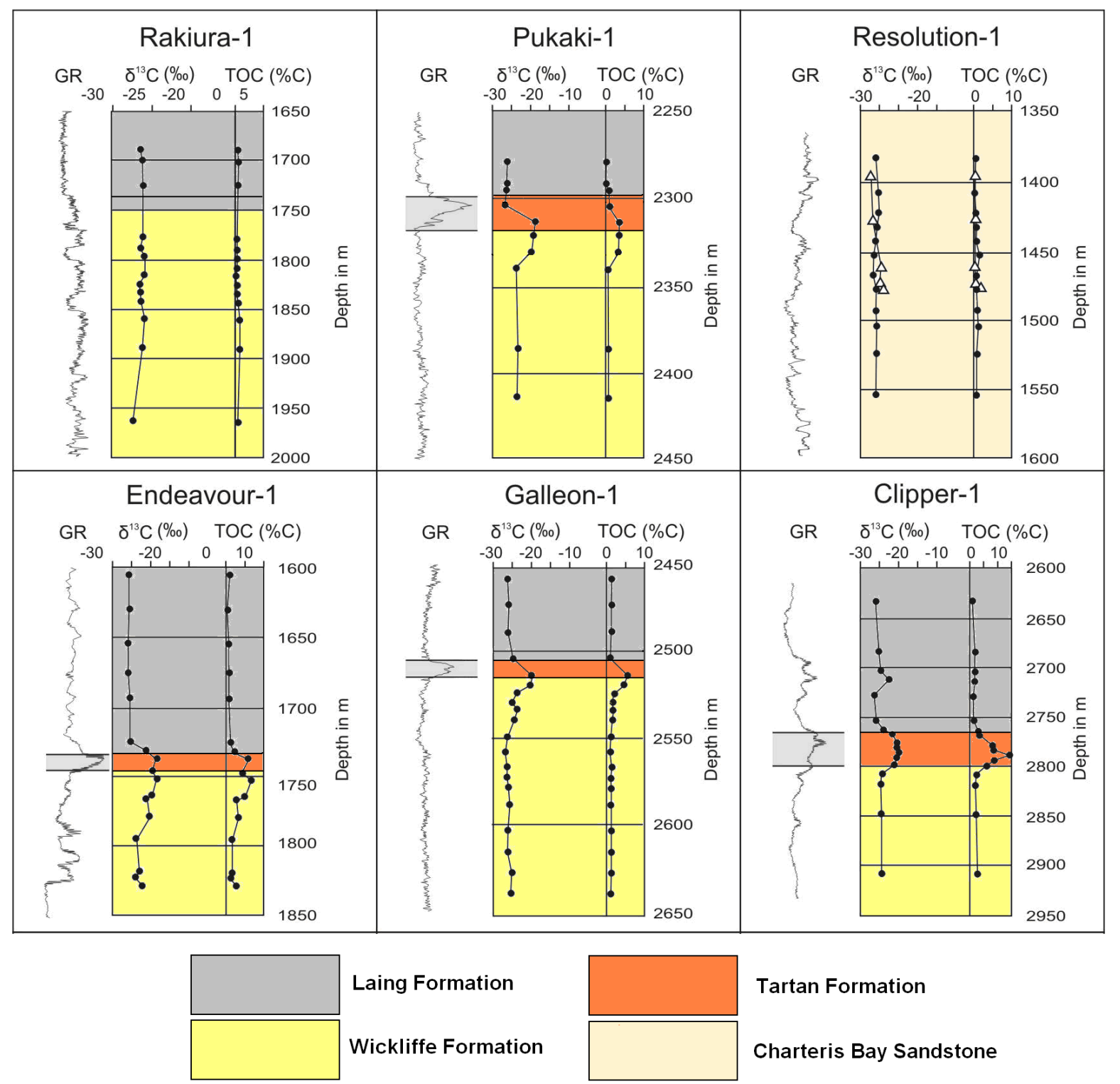

Figure 7.1 Geochemical comparisons to gamma ray log data (Shaded areas of the GR logs represent the Tartan Formation interval, solid points represent cuttings samples, and hollow points are sidewall core samples. Also note the variable depth and chemical scales for each well).

From this figure, it is evident that the GR response generally correlates to at least part of the geochemical excursions shown by the TOC and $\delta^{13} \mathrm{C}$ records. It appears that, in wells where the Tartan Formation is present, the GR excursion occurs towards the top of the geochemical excursion, which often exceeds the limits of the GR excursion. This is a possible result of sample contamination from cuttings, where samples from higher depths

Dylan Meadows, 2009. 
Chapter 7. Discussion

are incorporated into samples received from deeper in the borehole; thus providing an offset indication of geochemical boundaries. However, it is likely that the depth differences between the GR and geochemical excursions in Pukaki-1, Endeavour-1, and possibly Galleon-1 are not caused solely by cuttings contamination from shallower samples. It appears that the deepest GR excursion finishes well above the deepest excursions of the geochemical data in these three wells. Small differences between GR and geochemical data can be attributed to cuttings contamination, but the larger variance observed is more likely controlled by the type of organic matter contained within the samples. As the GR log is a lithology log, changes in the properties of the strata encountered within the well influence its response depending upon the amount and distribution of the natural radiation present in a formation. The TOC and $\delta^{13} \mathrm{C}$ values recorded in this study measure the quantity and type of organic carbon present in the formation. It is possible that the onset of the event associated with the geochemical changes began prior to the change in lithology, which would account for the differences in the data.

Meadows (2008) used the term "geochemical facies" to distinguish the differences between the GR response (as defining the formation boundaries) and the geochemical data over this interval. In light of the data obtained from the present study and further research into the global isotopic changes during the Paleocene, it appears that these geochemical changes prior to the recognised base of the Tartan Formation and the geochemical changes of the formation are associated with the Paleocene Carbon Isotope Maximum (PCIM) (see Chapter 3, Chapter 4, and Section 7.4).

\subsection{Source of organic matter in samples from the Great South and Canterbury basins}

$\mathrm{C} / \mathrm{N}$ ratios from samples within the Tartan Formation interval (Figure 7.2) range from 22 to 38 , and TOC contents range from 1.8 to $11.7 \%$, with most samples having $\mathrm{C} / \mathrm{N}$ ratios between 22 and 30, and TOC between 2 and $7 \%$.

Dylan Meadows, 2009. 
$\mathrm{C} / \mathrm{N}$ ratios vs TOC-Tartan Formation only

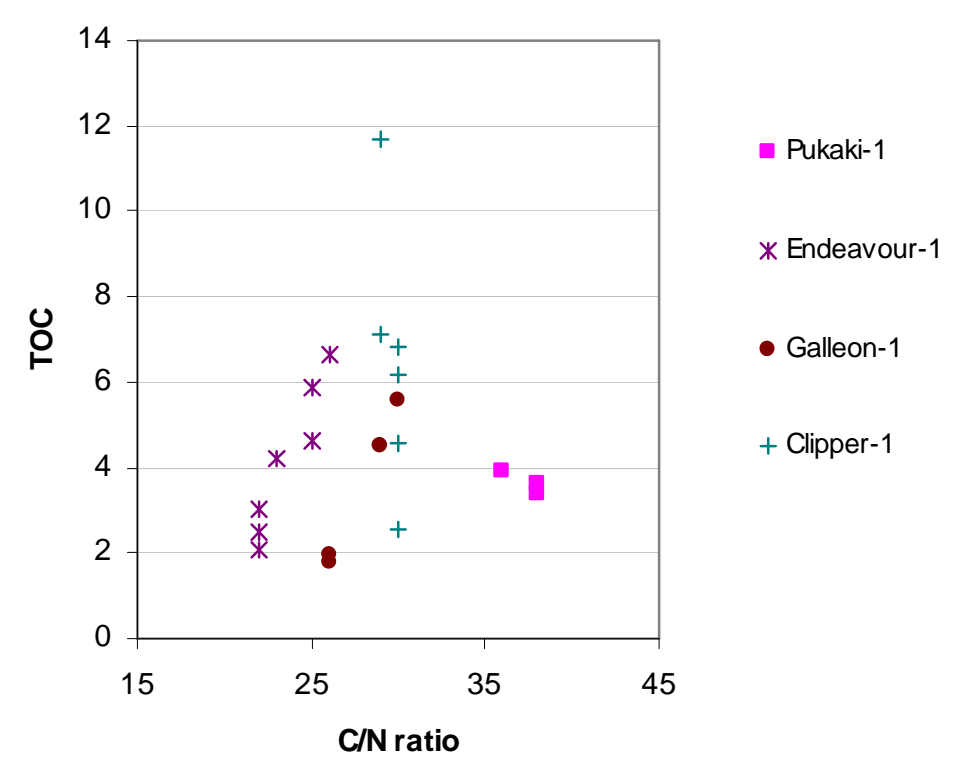

Figure 7.2 C/N vs. TOC for samples from the Tartan Formation.

Figure 7.2 displays the general trend of large increases in TOC content correlating positively with relatively small increases in $\mathrm{C} / \mathrm{N}$ ratios. Only one sample examined within the Tartan Formation interval had a TOC value below 2\% (Galleon-1; 2533 m, 1.8\%), and all samples had $\mathrm{C} / \mathrm{N}$ ratios above 20 , indicating a predominantly terrestrial organic matter source with some possible marine plant contribution. There is greater terrestrial influence on organic matter with increasing TOC content, possibly as a result of enhanced organic matter preservation with increasing terrestrial composition. The elevated $\mathrm{C} / \mathrm{N}$ ratios likely indicate reduced organic matter degradation associated with suboxic conditions within the water column. This would have led to preferential preservation of carbon-rich organic matter over nitrogenous components (Meyers et al. 2006). Microbial degradation under suboxic conditions by denitrification preferentially utilises nitrogenous compounds, such as amino acids (van Mooy et al. 2002) and proteinaceous matter, rather than carbon-rich compounds, such as carbohydrates (Verardo and MacIntyre, 1994) and $\mathrm{C}_{3}$ and $\mathrm{C}_{4}$ high-cellulose plants (Meyers, 1994). This leaves higher proportions of nitrogen-poor components in the sediments, resulting in higher $\mathrm{C} / \mathrm{N}$ ratios. Data from this study suggest that similar conditions and events could have influenced the organic matter contained within Tartan Formation sediments, resulting in the high $\mathrm{C} / \mathrm{N}$, high TOC results observed. 
Chapter 7. Discussion

Samples from the Tartan Formation are clearly distinct from samples from the enclosing formations (Fig. 7.3).

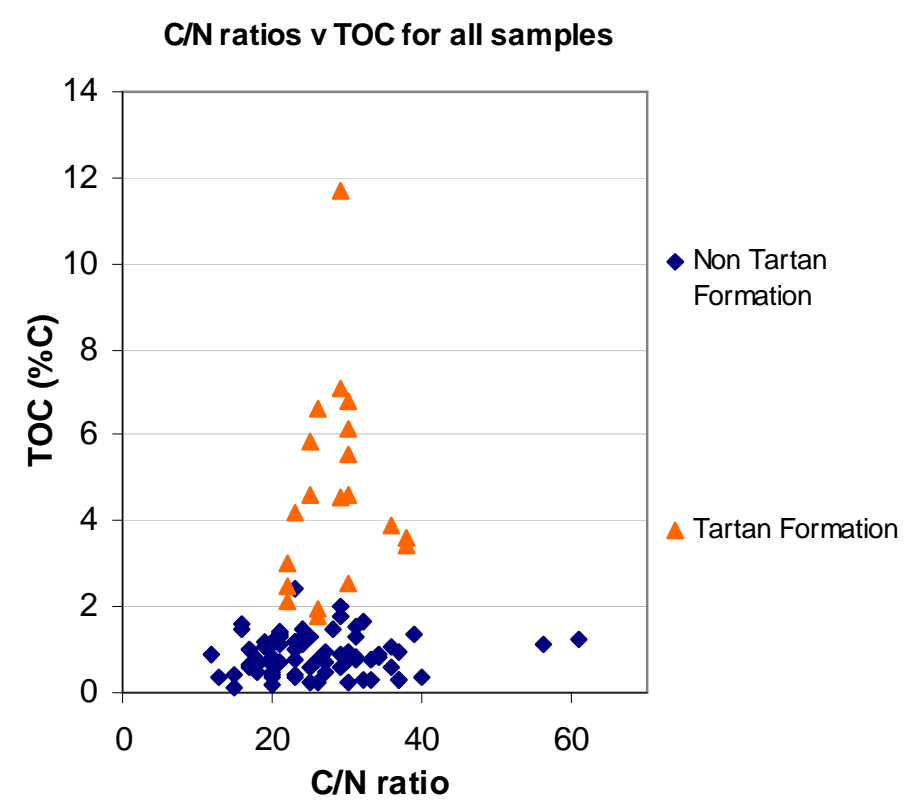

Figure $7.3 \mathrm{C} / \mathrm{N}$ vs. TOC for all samples analysed in this study.

From Figure 7.3, it is evident that there is much less variation in the $\mathrm{C} / \mathrm{N}$ ratios of the Tartan Formation samples than from samples of adjacent formations. All but two samples from enclosing formations have TOC contents below $2 \%$, and the trend of $\mathrm{C} / \mathrm{N}$ vs. TOC is almost linear, whereas samples from the Tartan Formation typically display greater terrestrial influence on organic matter with increasing TOC content. This indicates that TOC has little effect on the $\mathrm{C} / \mathrm{N}$ ratio of Tartan Formation samples compared to those from enclosing formations.

There are many samples from the underlying and overlying formations that have $\mathrm{C} / \mathrm{N}$ ratios below 20, indicating a marine plant and algal or mixed marine/terrestrial source. There are also many samples that have $\mathrm{C} / \mathrm{N}$ values at or above 20 , indicating higher proportions of terrestrial components in the organic matter. The change in $\mathrm{C} / \mathrm{N}$ ratio without a corresponding change in the TOC amongst samples from enclosing formations could be explained by the conditions surrounding preservation, and by differences in the extent of microbial activity degrading nitrogenous compounds of the organic matter (see below). Dumitrescu and Brassell (2006) suggest that samples with uniform $\mathrm{C} / \mathrm{N}$ ratios could 
represent organic matter derived from a uniform source; this indicates that samples from the Tartan Formation (Fig. 7.2) have a much more uniform source of organic matter than adjacent formations (Fig. 7.3).

Examination of the individual data points for $\mathrm{C} / \mathrm{N}$ ratios plotted against $\delta^{13} \mathrm{C}$ values from each well from samples of the Tartan Formation (Fig. 7.4) shows a grouping of samples for each well (with the exception of Galleon-1, which is divided into two separate sub-clusters). The distinct grouping of samples in each well suggests that the organic matter supply was similar, and variability across wells suggests that preservation and organic matter supply varied from place to place.

C/N ratios vs d13C-Taratn Formation only

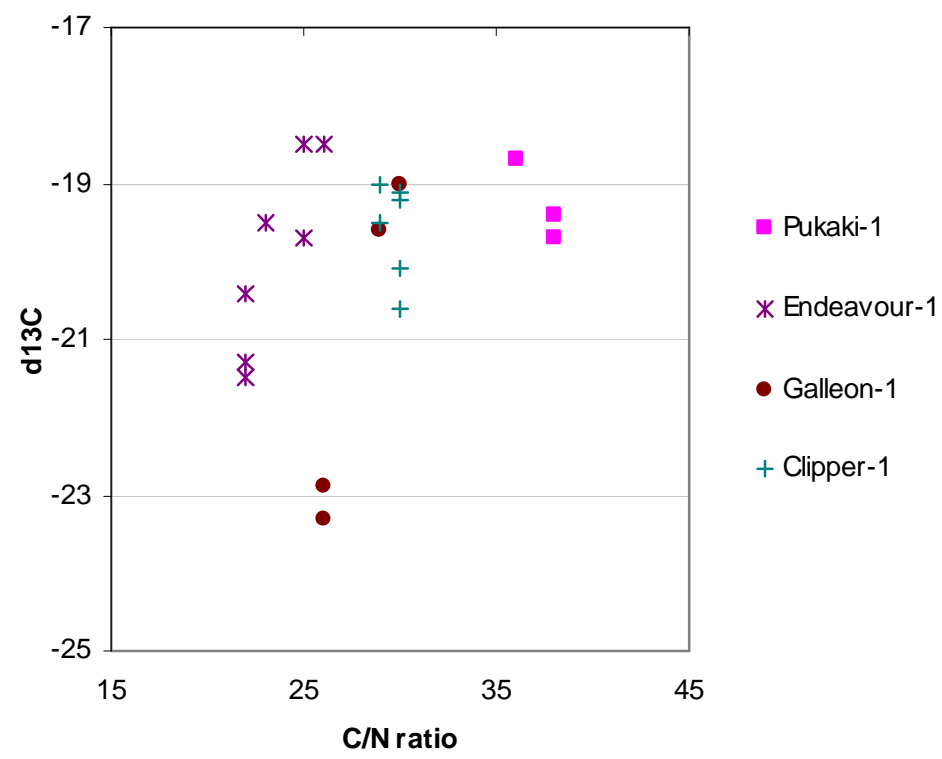

Figure $7.4 \mathrm{C} / \mathrm{N}$ vs. $\delta^{13} \mathrm{C}$ data for samples from the Tartan Formation interval.

$\delta^{13} \mathrm{C}$ ratios around $-20 \%$ are typical of organic matter derived from $\mathrm{C}_{3}$ marine plants/algae/bacteria (White, 2001), and heavier isotopic ratios of approximately -14\%o are characteristic of $\mathrm{C}_{4}$ land plants (Meyers, 1994); however, it is unlikely that any $\mathrm{C}_{4}$ land plant material would be present in samples from the Late Paleocene Tartan Formation as this plant type has been reported to have only developed around 25-30 Ma (Osborne and Beerling, 2006). Due to the high $\mathrm{C} / \mathrm{N}$ ratios of samples within the Tartan Formation, it would appear that a terrestrial source of organic matter is likely. However, $\delta^{13} \mathrm{C}$ analyses have 
given many isotopically heavy values, below $-20 \%$, that tend to indicate a mixed marine and terrestrial source.

Figure 7.5 shows that samples of the Tartan Formation interval almost all lie between marine plant/bacterial, $\mathrm{C}_{3}$ land plant and $\mathrm{C}_{4}$ land plant compositions. Thus, it is likely that the organic matter of the Tartan Formation is derived from a mixture of sources, both marine and terrestrial, with the differences being produced by variations in the relative proportion of each type of source material. There are variations in both $\delta^{13} \mathrm{C}$ and $\mathrm{C} / \mathrm{N}$ ratios indicating changes in the source of organic matter throughout deposition, coupled with variable levels of preservation throughout the depositional period.

\section{$\mathrm{C} / \mathrm{N} \vee \delta{ }^{13} \mathrm{C}$ for all samples}

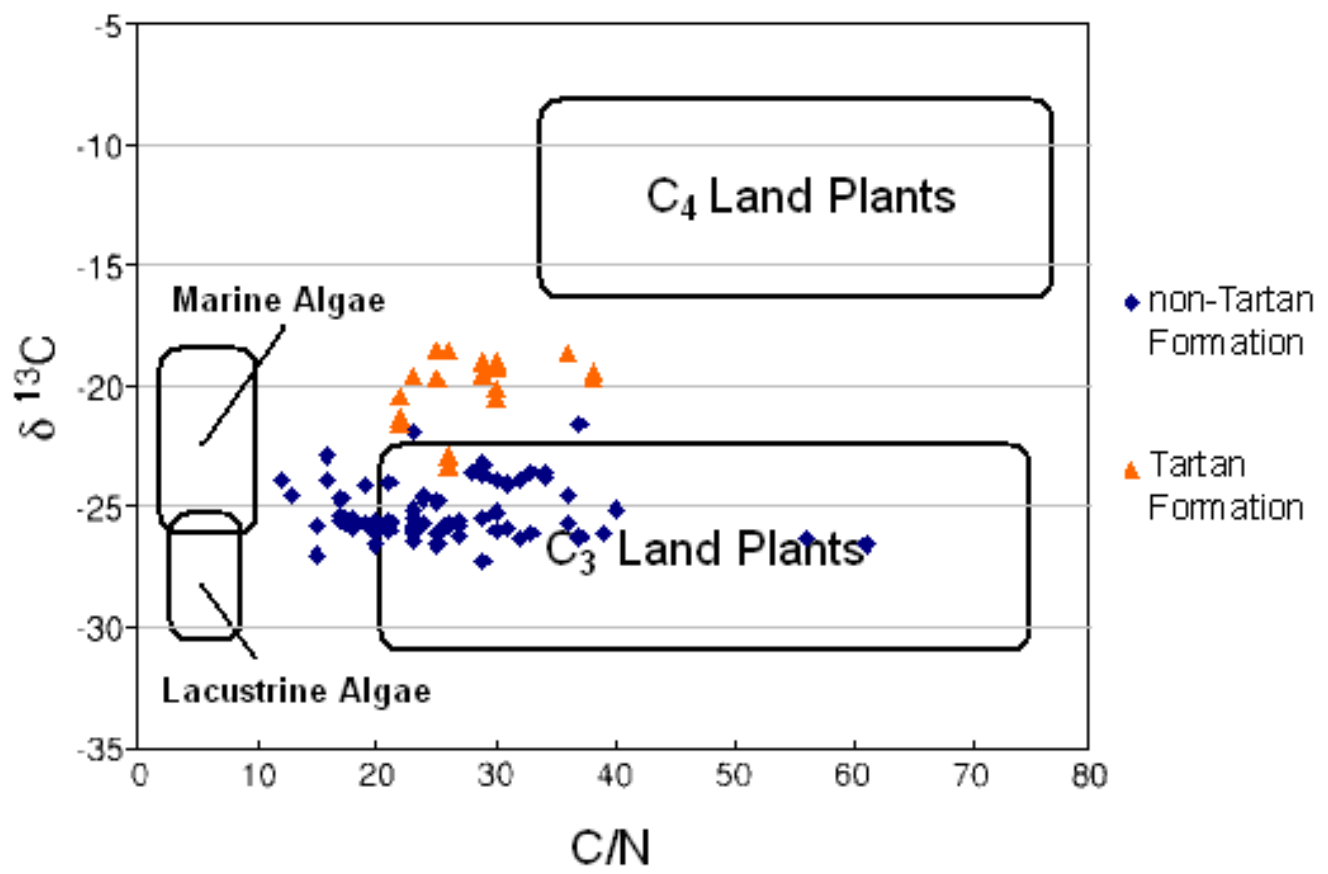

Figure 7.5 Comparison of $\mathrm{C} / \mathrm{N}$ vs. $\delta^{13} \mathrm{C}$ data from all samples analysed in this study, (including the above-mentioned Tartan Formation samples from Fig. 7.4) overlain onto a diagram modified from Meyers (1994; Fig. 1) The original diagram specified ranges for $\mathrm{C} / \mathrm{N}$ and $\delta^{13} \mathrm{C}$ values for different organic matter sources.

From Figure 7.5, Tartan Formation samples plot towards the lower $\mathrm{C} / \mathrm{N}$ end-member for $\mathrm{C}_{3}$ plants and towards the heavier $\delta^{13} \mathrm{C}$ range for marine algae. There are several samples from the Tartan Formation interval that recorded $\delta^{13} \mathrm{C}$ values towards the heaviest isotopic end-member range of marine algae. It is possible that these samples contain higher 
Chapter 7. Discussion

proportions of marine material than $\mathrm{C}_{3}$ terrestrial organic matter, giving the heavy isotopic character which they exhibit.

Figure 7.5 also displays samples from the immediately adjacent Wickliffe and Laing formations. There is a distinct difference between samples from the Tartan Formation and those of the enclosing formations. These samples generally lie within the $\delta^{13} \mathrm{C}$ range of -27 to $-23 \%$, and most $\mathrm{C} / \mathrm{N}$ ratios lie between 15 and 40 . This indicates that there were several sources for organic matter (also shown in Figure 7.6), deposited with varying degrees of preservation. The majority of non-Tartan Formation samples plot towards the lower endmember for $\mathrm{C} / \mathrm{N}$ ratios, and towards the middle and heavier end-member of the $\delta^{13} \mathrm{C}$ range for $\mathrm{C}_{3}$ land plants. Some of these samples appear to have a mixed terrestrial and marine character; such samples tend to plot on the lower end-member of the $\mathrm{C} / \mathrm{N}$ ratio for $\mathrm{C}_{3}$ land plants and the isotopically lighter end-member for $\delta^{13} \mathrm{C}$ marine algae. The data in Figure 7.5 suggest that the organic matter of the enclosing formations of the Tartan Formation was derived from a combination of $\mathrm{C}_{3}$ land plants and marine components, but predominantly contain terrestrial components.

In Figure 7.6 TOC data are compared to $\delta^{13} \mathrm{C}$ data. Again, there is a clear distinction between samples from the Tartan and adjacent formations.

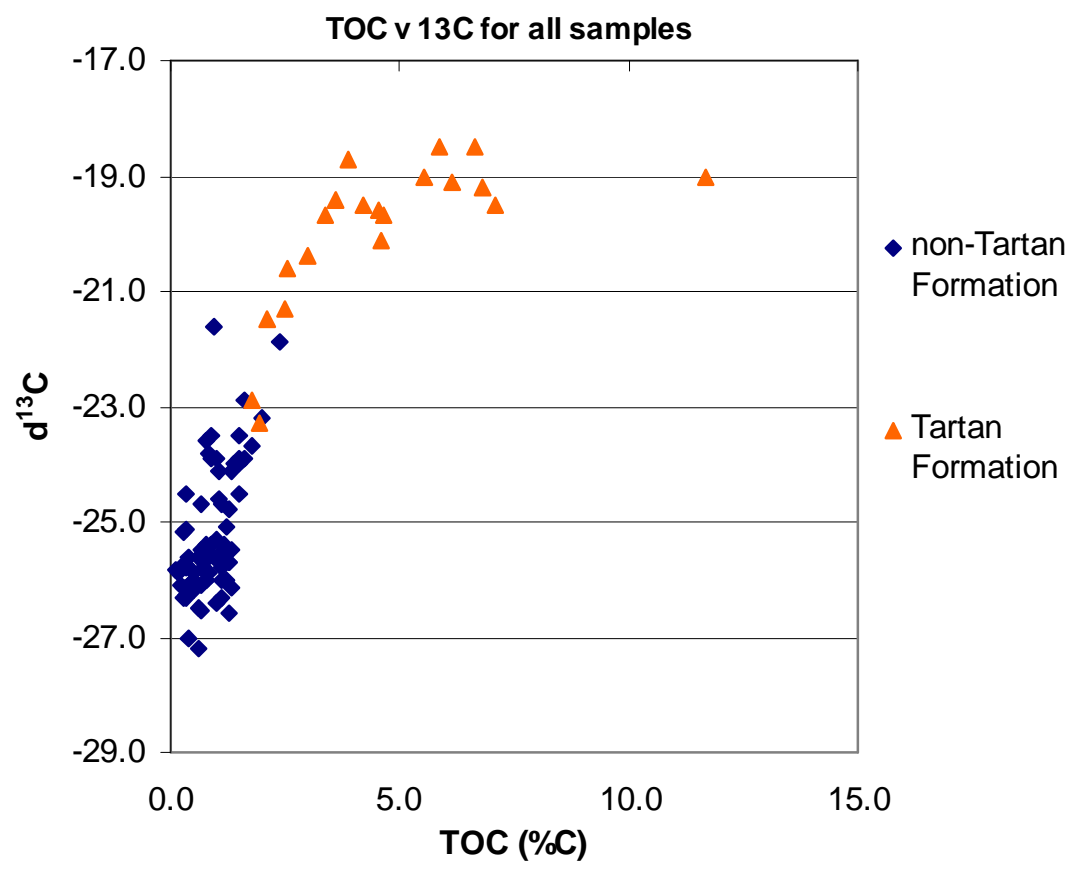

Figure 7.6 Comparison of TOC vs. $\delta^{13} \mathrm{C}$ for Tartan and non-Tartan Formation samples. 
Chapter 7. Discussion

The higher organic content samples correlate positively with heavier $\delta^{13} \mathrm{C}$ values within the Tartan Formation. Figure 7.6 also demonstrates that the Tartan has variable preservation of organic matter between wells, probably due to both depositional environment and organic input. This is shown by variations in TOC content for Tartan Formation samples from 1.8 to $11.7 \%$. Variations in $\delta^{13} \mathrm{C}$ values across wells within the Tartan Formation indicate a change in the source of organic matter (also see Fig. 7.5 and corresponding discussion).

\subsection{Correlation of latest geochemical data to Meadows (2008)}

This section will compare the results from the present study of the Canterbury and Great South basins to previous work from the Great South Basin undertaken by the author. The previous work is included with this thesis as an electronic copy of Meadows (2008) as supplementary data.

In the present study six well from the Great South and Canterbury basins were investigated. The Late Paleocene Tartan Formation was present in four of these wells (Pukaki-1, Endeavour-1, Galleon-1, and Clipper-1). The Late Paleocene to Early Eocene section of five other wells from the Great South Basin have previously been investigated by the author; of which, four contained Tartan Formation (Kawau-1A, Hoiho-1C, Pakaha-1, and Toroa-1). In total, eight of eleven wells investigated contain Tartan Formation (five from the Great South Basin, and three from the Canterbury Basin). Table 7.1 displays peak geochemical values recorded from both studies for each well where Tartan Formation was identified. 


\begin{tabular}{|c|c|c|c|c|}
\hline Well & Peak $8^{13} \mathrm{C}(\%)$ & Depth (m) & Peak TOC (\%) & Depth (m) \\
\hline Meadows (2008) & \multicolumn{5}{|c|}{ Cuttings } \\
\hline Kawau-1A & -17.4 & 2264 & 11 & 2264 \\
\hline Pakaha-1 & -19.3 & 2551 & 6.5 & 2551 \\
\hline Meadows (2008) & \multicolumn{5}{|c|}{ Sidewall core } \\
\hline Hoiho-1C & -15.8 & 1578 & 17.1 & 1578 \\
\hline Kawau-1A & -18.2 & 2240 & 9.3 & 2240 \\
\hline Pakaha-1 & -20.7 & 2576 & 5.3 & 2576 \\
\hline Toroa-1 & -21 & 2162 & 7.2 & 2162 \\
\hline Present study & \multicolumn{5}{|c|}{ Cuttings } \\
\hline Fukaki-1 & -18.7 & 2313 & 3.9 & 2313 \\
\hline Endeavour-1 & -18.5 & $1752 \& 1737$ & 6.6 & 1752 \\
\hline Galleon-1 & -19 & 2513 & 5.6 & 2513 \\
\hline Clipper-1 & -19 & 2788 & 11.7 & 2788 \\
\hline
\end{tabular}

Table 7.1 Peak $\delta^{13} \mathrm{C}$ and TOC values recorded from this study and that by Meadows (2008).

The data presented in Table 7.1 displays highly organic rich and isotopically heavy $\delta^{13} \mathrm{C}$ values for all wells containing the Tartan Formation. From well to well, peak TOC contents range from $3.9 \%$ in Pukaki-1, to a maximum of $17.4 \%$ in Hoiho-1C. $\delta^{13} \mathrm{C}$ values range from $-25 \%$ in Hoiho-1C, to $-15.8 \%$, also in Hoiho-1C, whereas C/ $\mathrm{N}$ ratios (see Appendix 3 and Appendix 4) range from 21 (Pakaha-1) to 44 (Hoiho-1C).

Tartan Formation samples from Pukaki-1 and Hoiho-1C contain the highest $\mathrm{C} / \mathrm{N}$ ratios ranging from 35 to $44 . \mathrm{C} / \mathrm{N}$ ratios within this range are indicative of plant material that has been derived from a predominantly terrestrial source. $\delta^{13} \mathrm{C}$ data recorded from Tartan Formation samples in these wells range from $-25 \%$ to $-15.8 \%$ o (both from Hoiho-1C), whereas the Pukaki-1 Tartan Formation samples range from $-19.7 \%$ o to $-18.7 \%$. This range of $\delta^{13} \mathrm{C}$ values are generally indicative of primarily marine sources of organic matter, such as algae, bacteria, and $\mathrm{C}_{3}$ marine plants. The conflicting $\mathrm{C} / \mathrm{N}$ and $\delta^{13} \mathrm{C}$ data of the source of organic matter from Hoiho-1C and Pukaki-1C most likely indicate that organic matter was derived from mixed $\mathrm{C}_{3}$ land plant, $\mathrm{C}_{3}$ marine plant, marine bacterial, and algal sources (Fig. 7.7).

Dylan Meadows, 2009. 


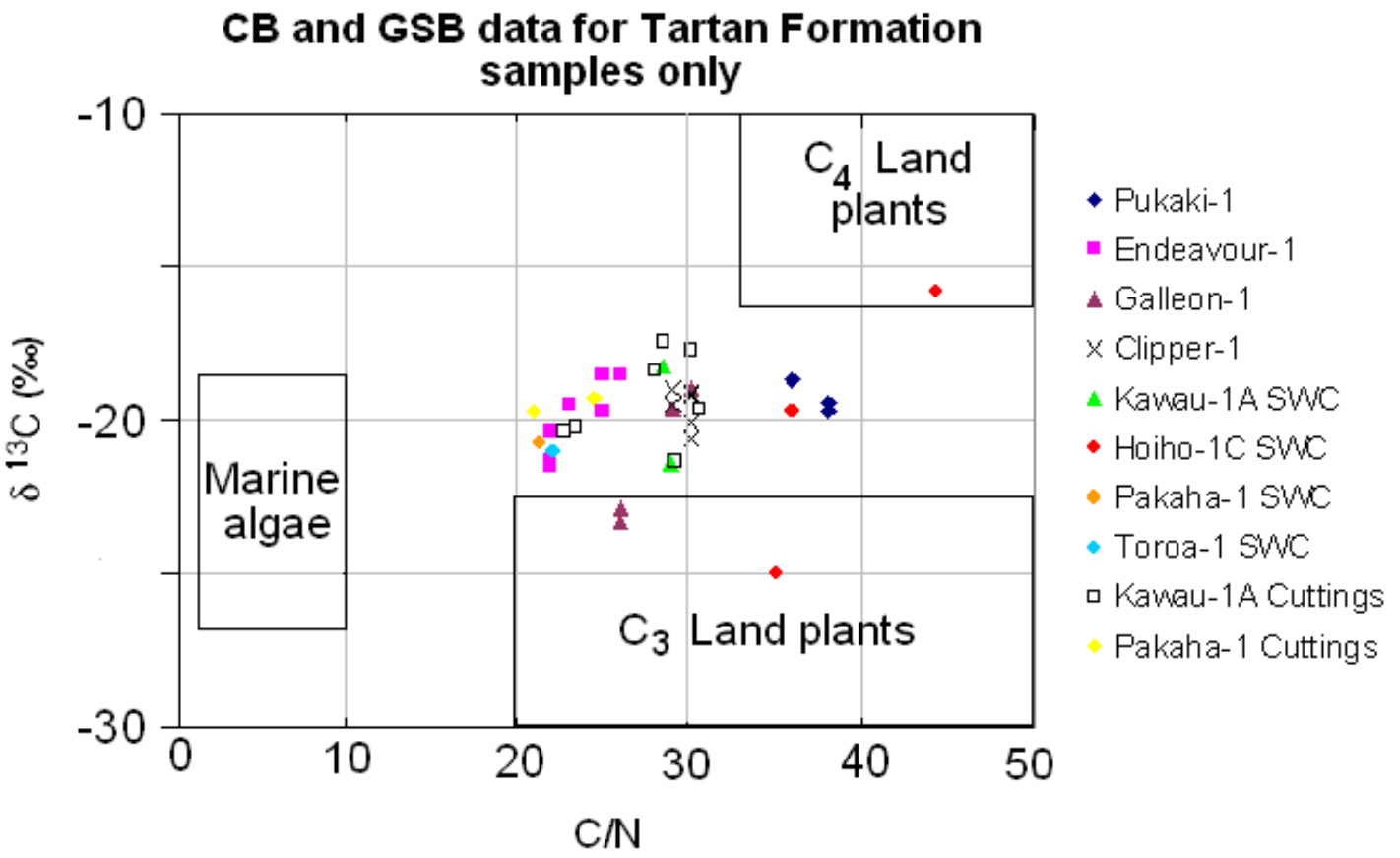

Figure $7.7 \mathrm{C} / \mathrm{N}$ and $\delta^{13} \mathrm{C}$ data for all samples lying within the Tartan Formation (Figure modified from Meyers, 1994).

Differences in values for these samples are likely due to differing proportions of each type of organic matter present in samples.

Tartan Formation samples from Endeavour-1, Galleon-1, Clipper-1, Kawau-1A, Pakaha-1, and Toroa-1 contain relatively similar geochemical values. $\mathrm{C} / \mathrm{N}$ ratios range from 21 to 31, TOC contents range from 1.8\% (Galleon-1) and 11.7\% (Clipper-1), while $\delta^{13} \mathrm{C}$ values range from -23.3\% (Galleon-1) to -17.4\%o (Kawau-1A).

$\mathrm{C} / \mathrm{N}$ ratios that lie between 21 and 31 are generally considered to contain organic matter that has been derived from a predominantly terrestrial source (Fig. 7.7). $\delta^{13} \mathrm{C}$ values between $-23.3 \%$ and $-17.4 \%$ are indicative of mixed marine and terrestrial plant sources (Fig. 7.6). As previously mentioned, differences in values between these Tartan Formation samples are likely due to differing compositions of marine and terrestrial components incorporated within the organic matter of a sample. The sample from Galleon-1 $(-23.3 \%)$ is likely to contain a high proportion of $\mathrm{C}_{3}$ land plant material, whereas the sample from Kawau-1A ($17.4 \%$ ) is likely to contain a much higher ratio of marine derived plant material. Differences in the TOC content between samples indicate perturbations in factors affecting the preservation and accumulation of organic matter, such as; organic input, sedimentation rate, 
and sediment dilution, organic matter degradation by biological reworking, and other environmental factors.

Figure 7.8 is a well by well plot of $\mathrm{C} / \mathrm{N}$ v. TOC for all wells containing Tartan Formation from the present study and the previous study by the author.

CIN v TOC for all Tartan Formation samples

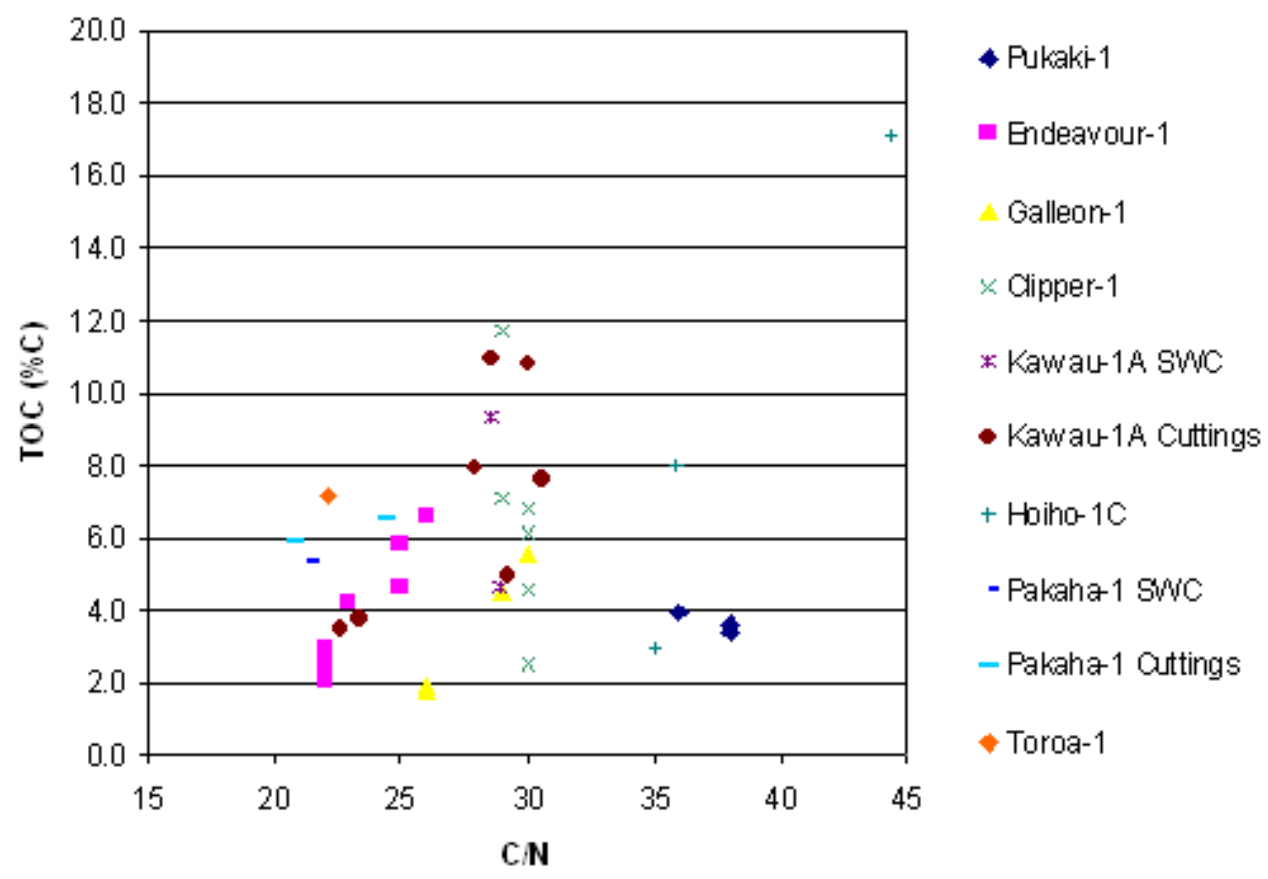

Figure 7.8 Well by well plot of Tartan Formation samples comparing $\mathrm{C} / \mathrm{N}$ and TOC for all wells containing Tartan Formation.

The figure typically demonstrates grouping of data points for each well examined. The general trend of Figure 7.8 is for highly variable TOC contents correlating with relatively constant $\mathrm{C} / \mathrm{N}$ ratios in any given well. This data suggests that there was a constant organic matter source with varying levels of preservation. The $\mathrm{C} / \mathrm{N}$ ratio differences between wells are a likely reflection of varying types or proportions of organic matter sources between wells. From the work presented by Meadows (2008) C/N ratios appear to increase with distance from the inferred paleoshoreline, indicating greater terrestrial influence in the more distal well sites in the Great South Basin. Schioler and Roncaglia (2008) have reported a similar trend for the Tartan Formation using detailed palynological analyses. From their work, an increase in non-marine proxies was recorded in the three most distal wells of the Great South Basin (Hoiho-1C, Kawau-1A, and Pakaha-1), and was interpreted to be the 
result of deposition during a peak regression during the Thanetian (Late Paleocene) (see Sections 3.5 and 7.4 for further discussion).

Figure 7.9 demonstrates increasingly heavy $\delta^{13} \mathrm{C}$ values correlating positively with increasing TOC contents amongst Tartan Formation samples for any given well. This trend indicates variable preservation between Tartan Formation samples in each well. The observed variations in $\delta^{13} \mathrm{C}$ values across Tartan Formation samples in a given well indicate changing organic matter source components, with a likely more marine influence on the heavier $\delta^{13} \mathrm{C}$ values and a mixed marine/terrestrial influence for the lighter $\delta^{13} \mathrm{C}$ values. The higher organic content of the heavier $\delta^{13} \mathrm{C}$ samples could suggest enhanced preservation of marine organic matter components over terrestrial components or a combination of greater preservation and accumulation of marine over terrestrial components.

\section{TOC $\vee \delta^{13} \mathrm{C}$ for all Tartan Formation samples}

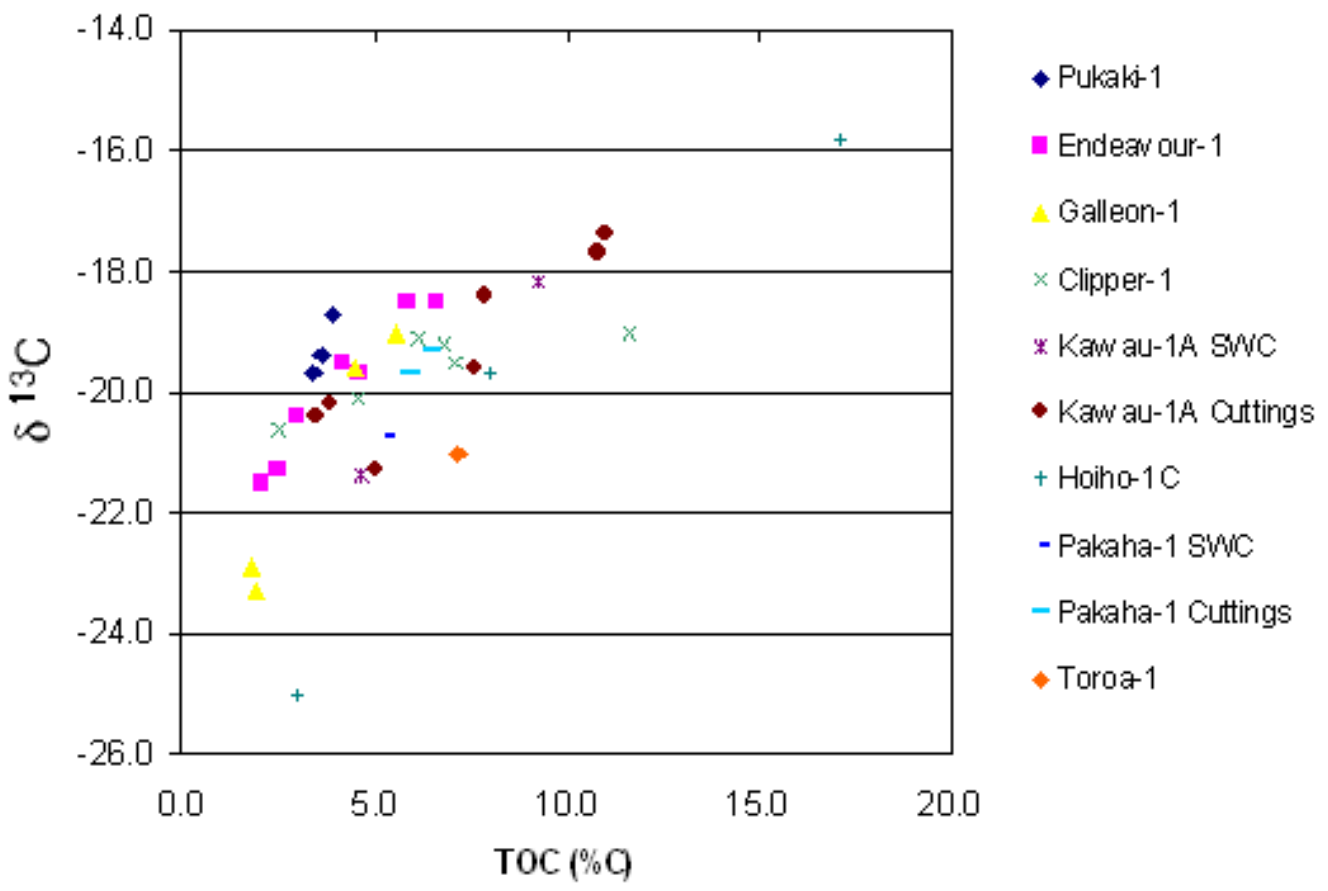

Figure 7.9 Well by well plot of Tartan Formation samples comparing TOC and $\delta^{13} \mathrm{C}$ for all wells containing Tartan Formation.

Data comparing TOC and $\delta^{13} \mathrm{C}$ for all Tartan Formation samples from both the present study and that by Meadows (2008) are presented in Figure 7.10. 


\section{TOC $\vee \delta^{13} \mathrm{C}$ for all Tartan Formation samples}

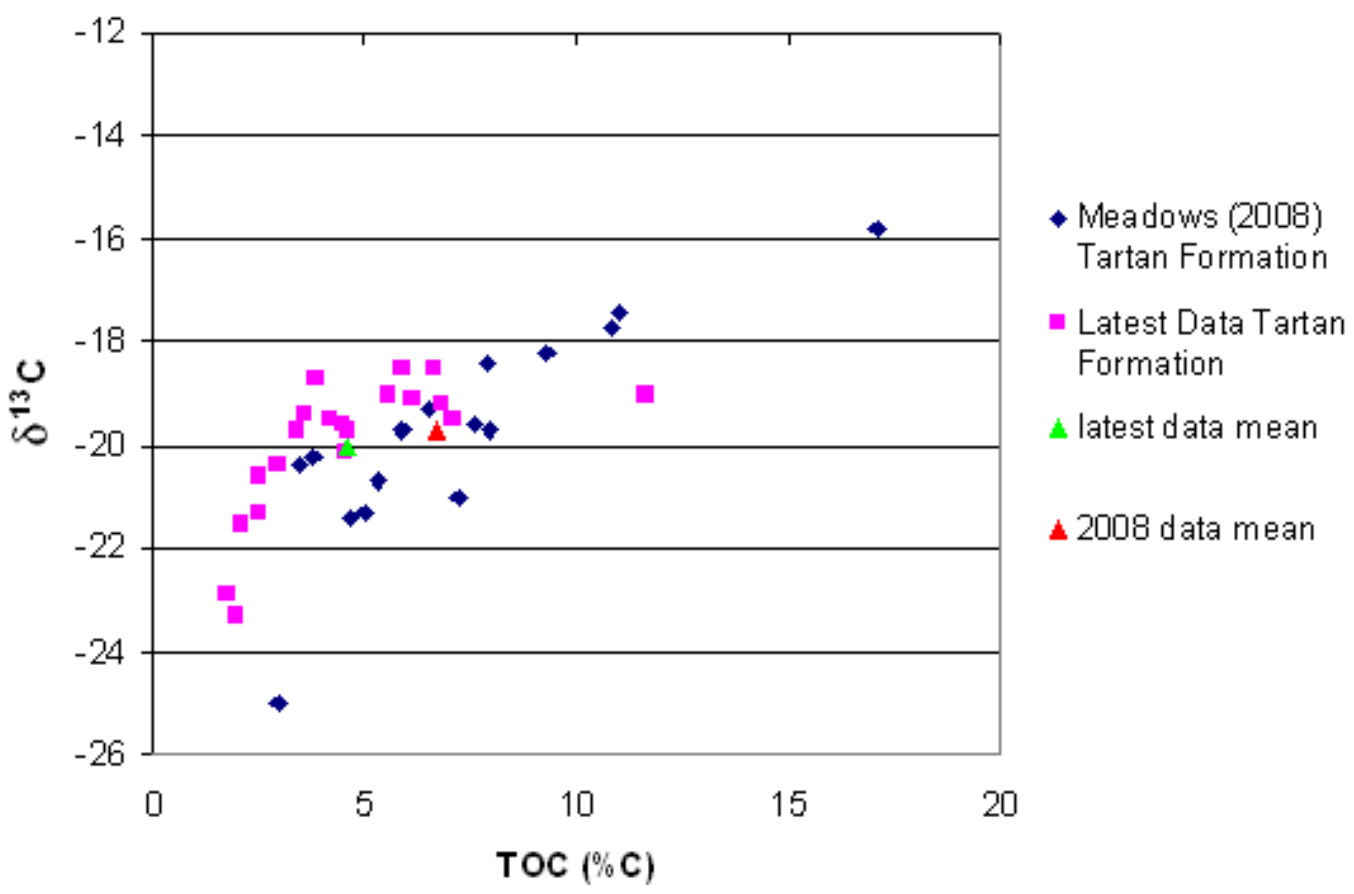

Figure 7.10 Comparison of latest data to the previous study of the Great South Basin by the author displaying differences in TOC and $\delta^{13} \mathrm{C}$ for all Tartan Formation samples.

Although there is some overlap between the data from the present study and that by Meadows (2008) in Figure 7.10, it is evident that the data sets are distinct from one another. The figure demonstrates the differences between the two studies, with an overall mean value for each study. These single data points represent the average TOC and $\delta^{13} \mathrm{C}$ values for all Tartan Formation samples in each study. The mean data point for the present study (TOC = $4.6 \%, \delta^{13} \mathrm{C}=-20 \%$ ) has a lighter $\delta^{13} \mathrm{C}$ value and a lower organic content than that of the mean data point from the 2008 study (TOC $=6.7 \%, \delta^{13} \mathrm{C}=-19.7 \%$ ). While the bulk of the data points from both data sets share similar $\delta^{13} \mathrm{C}$ values, it is evident from the figure that the samples from wells in the 2008 study of the Great South Basin generally contain higher TOC contents. The 2008 data also has much heavier $\delta^{13} \mathrm{C}$ and TOC end-members, particularly those from Kawau-1A and Hoiho-1C.

Differences in paleoenvironmental conditions between the Great South and Canterbury basins are a likely cause for the observed trend in Figure 7.10. The Great South Basin would appear to have had, on average, greater organic matter input than that of the Canterbury Basin during deposition. If this is true, it was likely combined with greater organic 
preservation of deposited organic matter. These regional variations are the likely result of differences in the paleogeography of the area, and differences in the geochemistry reflect the extent in which the paleoenvironmental conditions influenced organic matter input, preservation, and accumulation. Causes for the variation in $\delta^{13} \mathrm{C}$ values between well sites are further discussed below.

\subsection{Comparison of the Tartan Formation to the Waipawa Formation and the PCIM}

The enrichment of ${ }^{13} \mathrm{C}$ and the high TOC contents within the Tartan Formation of the Great South and Canterbury basins are consistent with that of the mid to Late Teurian Waipawa Formation elsewhere around New Zealand; however, samples from Hoiho-1C (1554 m; -15.8\%o) and Kawau-1A (2264 m; -17.4\%o) have $\delta^{13} \mathrm{C}$ and TOC values that exceed those previously reported for the Waipawa Formation (Killops et al. 2000; Rogers et al. 2001; Hollis et al. 2006). Hollis et al. (2006) reported a $\delta^{13} \mathrm{C}$ value of $-17.5 \%$ for one Waipawa Formation sample from the mid-Waipara River outcrop (inland Marlborough) which is the heaviest recorded $\delta^{13} \mathrm{C}$ value for the formation. From Killops et al. (2000), Rogers et al. (2001), and Hollis et al. (2006), the heaviest $\delta^{13} \mathrm{C}$ values for Waipawa Formation (apart from the mid-Waipara River sample) generally range from $-18.5 \%$ o to $-21 \%$, whereas values of $18.5 \%$ to $-19 \%$ are common throughout Tartan Formation samples from the Great South and Canterbury basins.

The Tartan and Waipawa formations are defined by lithology. It is possible that the oceanographic environmental events that produced the geochemical changes associated with the deposition of the Tartan and Waipawa formations were synchronous; however, the age of the Waipawa Formation, (as reported by Killops et al. 2000; Rogers et al. 2001; Hollis et al. 2006), and the Tartan Formation (as reported by Schioler and Roncaglia, 2008) vary slightly depending on the basin each study focused on. Hollis et al. (2005) have mentioned the Waipawa Formation may represent a facies that developed during the Paleocene Carbon Isotope Maximum (PCIM) (see Chapter 4; Figure 4.1), but at different times and slightly different lithostratigraphic stages, depending on local conditions (such as: water depth, sediment supply, basin subsidence rates, nutrient levels, and biologic productivity). Thus, differences in apparent age of the Tartan/Waipawa Formation around New Zealand may be attributed to the influence of local conditions on the onset of deposition. 
Chapter 7. Discussion

Carbon isotopic evidence presented by Killops et al. (2000) from East Coast Basin outcrops show that the start of the geochemical changes correspond to the lithological base of the Waipawa Formation. Rogers et al. (2001) give geochemical data for two East Coast Basin outcrops: Tawanui and Angora Stream. The Tawanui outcrop has no Waipawa Formation present; however, the Te Uri Member is present and is proposed as a Waipawa Formation equivalent. The Angora Stream section has Waipawa Formation present and no Te Uri Member is identified. In other outcrops, the Te Uri Member is overlain by Waipawa Formation (Moore 1988b, 1989). Rogers et al. (2001) concluded that the upper part of the Te Uri Member is a correlative to the Waipawa Formation.

However, geochemical data from some wells in the Great South and Canterbury basins demonstrate increases in TOC and isotopically heavy $\delta^{13} \mathrm{C}$ values that appear below the recognised base of the Tartan Formation, in the upper Wickliffe Formation. It is possible that the geochemical change observed prior to the base of the Tartan Formation in some wells is caused by a similar geochemical change below the Waipawa Formation as documented in the East Coast Basin. This could indicate that the Tartan Formation (which is recognised by GR response) is only equivalent to the middle and upper parts of the Waipawa Formation, whereas the geochemical changes (characterised by TOC and $\delta^{13} \mathrm{C}$ values) that occur below the recognised base of the Tartan Formation is related to the onset of the PCIM. This suggests that the termination of the PCIM was diachronous and differences in the lithostratigraphic expression of the Tartan and Waipawa formations could be the result of local environmental variations during deposition in the PCIM, affecting regions at slightly different times, and was more prominent in some areas. Thus, it is concluded here that differences in local conditions within the same overall framework define the variations between the Tartan and Waipawa formations.

$\delta^{13} \mathrm{C}$ and TOC excursions typical of the Tartan Formation are not ubiquitous throughout the Great South and Canterbury basins, and the formation has variable thickness (and possibly age) throughout the basins. Schioler and Roncaglia (2008) reported that the Tartan Formation was absent from the three most proximal wells drilled in the Great South Basin (Takapu-1A, Tara-1, and Rakiura-1). Schioler and Roncaglia (2008) also mentioned that these three wells form a coast-parallel transect landward of the five wells where Tartan Formation is present, which is believed to have resulted in sediment bypass or erosion of the Tartan Formation in the three most proximal wells during a peak regression and coastline 
Chapter 7. Discussion

progradation during the Thanetian (see Chapter 3). Hollis et al. (2006) reported the presence of Waipawa Formation in outcrops at Black's Quarry and Whatuwhiwhi (Northland Basin), but the formation was absent from the nearby Price's Quarry outcrop. The Ariki-1 exploration well in the Taranaki Basin contains Tartan Formation (Killops et al. 2000), however is absent from other wells in the basin. As previously mentioned, the Waipawa Formation is present in many outcrops in the East Coast Basin (Te Hoe River, Angora Stream, Te Waeroa Stream) but is absent at Tawanui. From the present study, it is believed that the Tartan Formation is absent in the nearshore Resolution-1 (Canterbury Basin) exploration well; however, the formation is present in the more distal wells of the basin (Endeavour-1, Galleon-1, and Clipper-1).

The presence of the Tartan and Waipawa formations in some areas of a basin and the absence of it in other areas indicate local conditions influenced deposition. Great South and Canterbury basin wells that contain Tartan Formation also show positive $\delta^{13} \mathrm{C}$ excursions, which indicate that the environmental changes during the PCIM affected these areas of the basins, whereas wells where the Tartan Formation is absent (unless eroded), the PCIM was not felt in that part of the basin, or was not intense enough to alter the $\delta{ }^{13} \mathrm{C}$ record. In some wells, the $\delta^{13} \mathrm{C}$ excursion occurs below the recognised base of the Tartan Formation (see Fig 7.1 from this work, and Fig 7.2 from Meadows, 2008), which suggests that changes in the depositional environment occurred during the initial/early stages of the PCIM. Similar conditions are likely to have prevailed in the East Coast and Northland basins. The relatively short distances between the Tawanui (Waipawa Formation absent) and Angora Stream (Waipawa Formation present) outcrops, and the short distance between the Black's Quarry (Waipawa Formation present) and Price's Quarry (Waipawa Formation absent) outcrops suggest that the global environmental changes that resulted in the PCIM only influenced localised areas that were most favorable to organic matter preservation and accumulation. Hollis et al. (2005) suggested that the Waipawa Formation was deposited during the onset of the PCIM under an expanded oxygen minimum zone (OMZ) that is associated with condensed sedimentation. Thus, areas that did not experience this OMZ were unlikely to have been capable of accumulating and preserving a sufficient quantity of the organic matter containing enriched ${ }^{13} \mathrm{C}$ (that is representative of the PCIM) to noticeably alter the $\delta^{13} \mathrm{C}$ record.

Dylan Meadows, 2009. 
Chapter 7. Discussion

Kurtz et al. (2003) have stated that the PCIM likely represents a period of enhanced accumulation and burial of terrestrial organic matter, and Stott et al. (1996) mentioned that the isotopic changes that were recorded in the deep sea were transferred to the terrestrial carbon reservoirs via the atmosphere. In areas that were affected by the PCIM, the plant material that was deposited would be expected to contain a ${ }^{13} \mathrm{C}$ record of those changes. The author believes that the Tartan and Waipawa formations provide such a record, as organic carbon buried in sediment retains the carbon isotopic composition of its source, which reflects the isotopic record from the carbon reservoir from which it was derived.

As discussed earlier, the Tartan Formation coincides with part of the PCIM excursion. The observed diachrony of the Tartan Formation across the Great South and Canterbury basin, which the author believes to have been the result local variations across the area of deposition, is evidence of the Tartan Formation having been deposited at slightly different times during the PCIM. Variation in local conditions affecting the onset and duration of Tartan Formation deposition resulted in slightly different lithostratigraphic expressions of the Tartan Formation from one location to the next in the Great South and Canterbury basins. This reflects different representations (in timing) of the PCIM from one site to the next (where Tartan Formation is present). Thus, in a given well, the Tartan Formation's $\delta^{13} \mathrm{C}$ excursion correlates to part of the PCIM, but variations in local conditions across the basins have determined which part of the PCIM is represented in a given site. The Great South Basin appears to have had higher organic input than the Canterbury Basin. This is likely coupled with conditions favoring greater preservation of deposited organic matter. These regional variations are the probable result of differences in the paleogeography of the area, and differences in the geochemistry reflect the extent in which paleoenvironmental conditions influenced organic matter input, source, preservation, and accumulation.

The data presented by Zachos et al. (2001; Figure 2) suggest that the PCIM event took place over approximately $4 \mathrm{Myr}$, between 59.5 and $55.5 \mathrm{Ma}$ (mid to Late Paleocene). As discussed in Chapter 3, the depositional age of the Tartan and Waipawa Formations varies from approximately 58 to $55.5 \mathrm{Ma}$. The common $\delta^{13} \mathrm{C}$ excursion of the Tartan and Waipawa formations span the duration of time in which a particular site's environment (where the Tartan or Waipawa formations were deposited) was influenced by the changing organic matter of the PCIM. From the information available to the author at present, no precise time constraints can be placed on the deposition of the Tartan Formation. Estimates from the 
Chapter 7. Discussion

present information can only constrain the deposition of the Tartan Formation (and similarly the Waipawa Formation) to within part of the PCIM period (of which the author believes the effects of vary between sedimentary basins and also between sites within those basins). Based on these considerations, the author believes that the Tartan Formation is a correlative of the Waipawa Formation but that it is premature to synonymise the two.

It maybe that the peak $\delta^{13} \mathrm{C}$ excursions observed in Kawau-1A and Clipper-1 (both of which are well sampled wells that have a smooth set of data points both leading up to and following the peak $\delta^{13} \mathrm{C}$ value) reflect the peak of the PCIM (approximately 57 to $56 \mathrm{Ma}$ ). It may also represent a period where the environmental conditions were most augmented in that area. Hoiho-1C recorded the heaviest $\delta^{13} \mathrm{C}$ value $(-15.8 \%$ ) of all wells examined, possibly indicating that the PCIM had the greatest influence around Hoiho-1C during deposition. This sample from Hoiho-1C also considerably exceeds all previously reported $\delta^{13} \mathrm{C}$ values for the Waipawa Formation, suggesting that the environmental changes during the PCIM were greater around the Hoiho-1C area than elsewhere around New Zealand where the Tartan and Waipawa formations were deposited. 
Chapter 8. Conclusions

\section{CHAPTER 8}

\section{CONCLUSIONS}

- There is no geochemical evidence for the presence of the Tartan Formation in Rakiura-1, Takapu-1A, and Resolution-1.

- Geochemical studies of the six wells examined here, and five other wells from the previous study show that, in general, the Tartan Formation is distinct from enclosing formations and can be recognised by enrichments in TOC and ${ }^{13} \mathrm{C}$, with $\mathrm{C} / \mathrm{N}$ ratios above 20 . These changes agree well with the top of the formation as defined by its lithology.

- The high organic richness of the Tartan Formation with respect to the relatively low organic richness of adjacent formations establishes that there was a profound change in the conditions under which the Tartan Formation was deposited.

- In some wells geochemical changes appear below the recognised lithological base of the Tartan Formation, in the upper part of the underlying Wickliffe Formation. This is attributed to the onset of oceanographic environmental changes during the Paleocene Carbon Isotope Maximum (PCIM) that featured from the mid-Paleocene to the Late Paleocene, below the Paleocene-Eocene boundary.

- TOC data from Clipper-1 and Kawau-1A (the most comprehensively sampled wells) provide evidence for more favorable preservation and/or accumulation of organic matter during the mid stages of deposition of the Tartan Formation than during the initial and final stages. Further, TOC data for enclosing formations suggest that conditions for the preservation and accumulation of organic matter were more favorable prior to the deposition of the Tartan Formation than following it.

- All samples within the Tartan Formation have $\mathrm{C} / \mathrm{N}$ ratios above 20, with little variation. There appears to be a greater terrestrial influence on organic matter with increasing TOC content, possibly as the result of enhanced organic matter preservation with increasing terrestrial composition, and depressed organic matter degradation associated with suboxic conditions in the water column. 
Chapter 8. Conclusions

- It is probable that organic matter within samples of the Tartan Formation is composed of a mixture of $\mathrm{C}_{3}$ land plant and marine bacterial/plant/algal material, with the isotopically heavier samples containing a predominance of marine components and the lighter samples containing higher proportions of terrestrial source components. The organic matter within enclosing formations appears to have been derived primarily from $\mathrm{C}_{3}$ terrestrial plants sources.

- Samples from enclosing formations show a wide range of $\mathrm{C} / \mathrm{N}$ values. Many samples have $\mathrm{C} / \mathrm{N}$ ratios below 20, indicating a marine bacterial/plant/algal or mixed marine and terrestrial source. Many others that have $\mathrm{C} / \mathrm{N}$ ratios of 20 and above indicate a significant terrestrial composition. There is little variation in the TOC contents within these formations, with most samples having values below $2 \%$. This indicates that there were varying degrees of preservation of organic matter within these formations.

- Tartan Formation samples within a given well show a relatively close clustering of isotopic values, indicating a similar source of organic matter throughout deposition; however, it is evident that there are slight variations in the isotopic range between wells. This indicates that preservation and organic matter sources were variable across the areas where the Tartan Formation was deposited. Further evidence for varying degrees of preservation across Tartan Formation samples is provided by the positive correlation of increasingly heavy $\delta^{13} \mathrm{C}$ values corresponding to increasing TOC contents.

- The Great South Basin appears to have had higher organic input than the Canterbury Basin. This is likely coupled with conditions favoring greater preservation of deposited organic matter. These regional variations are the probable result of differences in the paleogeography of the area, and differences in the geochemistry reflect the extent in which paleoenvironmental conditions influenced organic matter input, source, preservation, and accumulation.

- Tartan Formation deposition coincides with the mid to Late Paleocene Waipawa Formation deposited elsewhere around New Zealand; however, TOC and $\delta^{13} \mathrm{C}$ values for the Tartan Formation exceed those previously reported for the Waipawa Formation. 
Chapter 8. Conclusions

- Geochemical changes below the lithological base of Tartan and Waipawa formations are contemporaneous with the PCIM, and represent different lithostratigraphic expressions of that event. Termination of the PCIM around New Zealand appears to have been diachronous and differences between the stratigraphic position of the Tartan and Waipawa formations are attributed to local geographical variations during deposition.

- It is concluded here that the Tartan and Waipawa formations are correlatives. However, two separate names are used for the formation as they are widely separated and no unequivocal relationship can be made between the formations based solely on the data from this study.

- TOC and $\delta^{13} \mathrm{C}$ enrichments associated with the Tartan Formation are not ubiquitous, and the formation has variable thickness throughout the Great South and Canterbury basins. This indicates that the environmental changes during the PCIM were more prominent in some areas than others, depending on local conditions. Thus, Tartan Formation deposition reflects different representations of part of the PCIM, depending on where and when each area was influenced by the event.

- TOC and $\delta{ }^{13} \mathrm{C}$ enrichments associated with the Tartan Formation span the time in which that area was affected by the PCIM. Peak values in Clipper-1 and Kawau-1A the most comprehensively sampled wells) may correspond to the peak effect of the PCIM in those wells. The enrichment of TOC and ${ }^{13} \mathrm{C}$ are greatest in Hoiho-1C, suggesting that the environmental changes during the PCIM influenced this area more than any other region where the Tartan Formation was deposited. 
References

\section{REFERENCES}

Anbar, A.D., Rouxel, O. 2007. Metal Stable Isotopes in Paleoceanography. Annual Review of Earth and Planetary Sciences 35, 717-746.

Asquith, G.B., Gibson, C.R. 1983. Basic Well Log Analysis for Geologists: American Association of Petroleum Geologists, Methods in Exploration Series: 216 pp.

Anderton, P.W., Holloway, N.H., Engstrom, J.C., Ahmad, H.M., Chong, B. 1982. Geological/geophysical exploration report. Evaluation of geology and Hydrocarbon potential of the Great South and Campbell basins. Petroleum Report 828. Crown Minerals, Ministry of Economic Development, New Zealand.

Baillie, P., Uruski, C. 2004. Reassessment of the prospectivity of the New Zealand Cretaceous: Navigating with an Astrolabe. In: 2004 New Zealand Petroleum Conference Proceedings, Crown Minerals, Ministry of Economic Development, New Zealand.

Beggs, J.M. 1993. Depositional and tectonic history of the Great South Basin. In: Balance, P.F. (Editor). South Pacific sedimentary basins. Sedimentary basins of the World 2 pp. 365-373. Amsterdam: Elsevier Science.

Cande, S.C., Kent, D.V. 1995. Revised calibration of the geomagnetic polarity timescale for the Late Cretaceous and Cenozoic. Journal of geophysical research 100, 6093-6095.

Carter, R.M. 1988a. Post breakup stratigraphy (Kaikoura Synthem: Cretaceous-Cenozoic) of the continental margin of southeastern New Zealand. New Zealand Journal of Geology and Geophysics 31, 405-429.

Carter, R.M. 1988b. Plate boundary tectonics, global sea-level changes, and the development of the eastern South Island continental margin, New Zealand, South Pacific. Marine and Petroleum Geology 5, 90-107.

Cook, R.A., Sutherland, R., Zhu, H. 1999. Cretaceous-Cenozoic Geology and Petroleum Systems of the Great South Basin, New Zealand. IGNS Monograph 20, Institute of Geological and Nuclear Sciences, Lower Hutt, New Zealand.

Corfield, R.M., Cartlidge, J.E. 1992. Oceanographic and climatic implications of the Palaeocene carbon isotope maximum. Terra Nova 4, 443-455.

Crown Minerals (2008a). Great South Basin Map. Retrieved February 27, 2008, from http://www.crownminerals.govt.nz/cms/images-old/petroleum/full-sizeimages/great-south basin map.gif

Crown Minerals (2008b). Canterbury Basin Map. Retrieved March 10, 2009, from http://www.crownminerals.govt.nz/cms/images-old/petroleum/full-sizeimages/canterbury basin map.gif 
References

Crown Minerals (2008c). New Zealand's Petroleum Basins. Retrieved July 23, 2008, from http://www.crownminerals.govt.nz/cms/pdf-library/petroleum-publications$1 /$ new-zealands-petroleum-basins-report

Crux, J.A., Eaton, G.L., Sturrock, S.J., Gibbons, M.J., Herridge, K.J. 1984. Clipper-1, Canterbury Basin, New Zealand; Biostratigraphy Report. Petroleum Report 1044. Crown Minerals, Ministry of Economic Development, New Zealand.

Dean, W.E., Arthur, M.A., Claypool, G.E. 1986. Depletion of ${ }^{13} \mathrm{C}$ in Cretaceous marine organic matter: Source, diagenetic, or environmental signal? Marine Geology 70, 119_ 157.

De Boer, P.L. 1986. Changes in the organic carbon burial during the Early Cretaceous. In: Summerhayes, C.P. and Shackleton, N.J. (Editors), North Atlantic Palaeoceanography. Geological Society London, Special Publications 21, 321-331.

Dumitrescu, M., Brassell, S.C. 2006. Compositional and isotopic characteristics of organic matter for the early Aptian Oceanic Anoxic Event at Shatsky Rise, ODP Leg 198. Palaeogeography, Palaeoclimatology, Palaeoecology 235, 168-191.

Emerson, S., Hedges, J.I. 1988. Processes controlling the organic carbon content of open ocean sediments. Paleoceanography 3, 621-634.

Field, B.D., Browne, G.H. 1989. Cretaceous and Cenozoic Sedimentary Basins and Geological Evolution of the Canterbury Region, South Island, New Zealand. New Zealand Geological Survey: Basin Studies 2, Institute of Geological and Nuclear Sciences, Lower Hutt, New Zealand.

Field, B.D., Uruski, C.I. et al. 1997. Cretaceous and Cenozoic Geology and Petroleum Systems of the East Coast Region, New Zealand. IGNS Monograph 19, Institute of Geological and Nuclear Sciences, Lower Hutt, New Zealand.

Finlay, H.J. 1940. New Zealand foraminifera: key species in stratigraphy No. 4. Transactions of the Royal Society of New Zealand 69(4), 448-472.

Fry, B., Brand, W., Mersch, J., Tholke, K., Garritt, R. 1992. Automated analysis system for coupled $\delta^{13} \mathrm{C}$ and $\delta^{15} \mathrm{~N}$ measurements. Analytical Chemistry 64, 288-291.

Geological and Nuclear Sciences (2003). Interim New Zealand Geological Timescale. Retrieved February 26, 2008, from http://www.gns.cri.nz/what/earthhist/dating/nzg/0603.xls.

Gibbons, M.J., Fry, S. 1986. A geochemical study of the Galleon-1 well, Canterbury Basin, offshore New Zealand. Petroleum Report 1146. Crown Minerals, Ministry of Economic Development, New Zealand.

Dylan Meadows, 2009. 
References

Grantham, P.J., Posthuma, J., De Groot, K. 1980. Variation and significance of the $\mathrm{C}_{27}$ and $\mathrm{C}_{28}$ triterpane content of a North Sea core and various North Sea crude oils. In: Douglas, A.G., Maxwell, J.R. (Editors), Advances in Organic Geochemistry 1979. Pergamon Press, New York, pp. 29-38.

Grassineau, N.V. 2006. High-precision EA-IRMS analysis of S and C isotopes in geological materials. Applied Geochemistry 21, 756-765.

Haq, B.Q., Hardonbol, J., Vail, P.R. 1987. Chronology of fluctuating sea levels since the Triassic. Science 235, 1156-1167.

Hawkes, P.W., Mound, D.G. 1984. Clipper-1 Geological Completion Report. Petroleum Report 1036. Crown Minerals, Ministry of Economic development, New Zealand.

Hayes, J.M. 1993. Factors controlling ${ }^{13} \mathrm{C}$ contents of sedimentary organic compounds: Principles and Evidence. Marine Geology 113, 111-125.

Hoefs, J. 2004. Stable Isotope Geochemistry, $5^{\text {th }}$ ed. Berlin: Springer-Verlag. 244pp.

Hollis, C.J., Dickens, G.R., Field, B.D., Strong, C.P. 2000. Age and origin of the Waipawa (black shale) Formation. Geological Society of New Zealand Miscellaneous Publication 108A, 77.

Hollis, C.J. 2003. The Cretaceous/Tertiary boundary event in New Zealand: profiling mass extinction. New Zealand Journal of Geology and Geophysics 46, 307-321.

Hollis, C.J., Dickens, G.R., Field, B.D., Jones, C.J., Strong, C.P. 2005. The Paleocene-Eocene transition at Mead Stream New Zealand: a southern Pacific record of early Cenozoic global change. Palaeogeography, Palaeoclimatology, Palaeoecology 215, 313-343.

Hollis, C.J., Field, B.D., Crouch, E.M., Sykes, R. 2006. How good a source rock is the Waipawa (Black Shale) Formation beyond the East Coast Basin? An outcrop-based case study from Northland. In: 2006 New Zealand Petroleum Conference Proceedings, Crown Minerals, Ministry of Economic Development, New Zealand.

Hornibrook, N.de B., Harrington, H.J. 1957. The status of the Wangaloan Stage. New Zealand Journal of Science and Technology 38B(6), 665-670.

Hornibrook, N.de B. 1959. Waipawa Black Shale (Siltstone). In: Fleming, C.A. ed. Lexique stratigraphique international 6(4), 443-444.

Hornibrook, N.de B. 1968. Handbook of New Zealand microfossils. D.S.I.R. Information Series 62: $136 \mathrm{pp}$.

Hornibrook, N.de B., Raine, J.I., Wilson, G.T. 1975. Report on the biostratigraphy of Resolution-1, offshore well. Petroleum Report 648. Crown Minerals, Ministry of Economic Development, New Zealand.

Dylan Meadows, 2009. 
References

Hornibrook, N.de B., Edwards, A.R. 1977. Report on the biostratigraphy of Pakaha No.1 offshore well. New Zealand Geological Survey Report PAL 15, 27p.

Hunt International Petroleum Co. 1977a. Well completion report, Kawau-1A, Great South Basin. Petroleum Report 716. Ministry of Commerce, Wellington, NZ.

Hunt International Petroleum Co. 1977b. Well completion report, Pakaha-1, Great South Basin. Petroleum Report 703. Ministry of Commerce, Wellington, NZ.

Hunt International Petroleum Co. 1977c. Well completion report, Toroa-1, Great South Basin. Petroleum Report 691. Ministry of Commerce, Wellington, NZ.

Hunt International Petroleum Co. 1978a. Well completion report, Hoiho-1C, Great South Basin. Petroleum Report 730. Ministry of Commerce, Wellington, NZ.

Hunt International Petroleum Co. 1978b. Well completion report, Takapu-1A, Great South Basin. Petroleum Report 733. Ministry of Commerce, Wellington, NZ.

Isaac, M.J., Herzer, R.H., Brook, F.J., Hayward, B.W. 1994. Cretaceous and Cenozoic Sedimentary Basins of Northland, New Zealand. IGNS Monograph 8, Institute of Geological and Nuclear Sciences, Lower Hutt, New Zealand.

Kaiho, K. 1991. Global changes of Paleogene aerobic/anaerobic benthic foraminifera and deep-sea circulation. Palaeogeography, Palaeoclimatology, Palaeoecology 83, 65-85.

Kaiho, K., Morgans, H.E.G., Okada, H. 1993. Faunal turnover of intermediate-water benthic foraminifera during the Paleogene in New Zealand. Marine Micropaleontology 23, 5186.

Kaiho, K. 1994. Benthic foraminiferal dissolved-oxygen index and dissolved-oxygen levels in the modern ocean. Geology 22, 719-722.

Kennett, J.P., Stott, L.D. 1991. Abrupt deep-sea warming palaeoceanographic changes and benthic extinctions at the end of the Paleocene. Nature 353, 225-229.

Killops, S.D., Raine, J.I., Woolhouse, A.D., Cook, R.A. 1994. A geochemical evaluation of oil generation in the Taranaki Basin. American Association of Petroleum Geologists Bulletin $78,1560-1585$.

Killops, S.D., Morgans, H.E.G., Leckie, D.A. 1996. The Waipawa Black Shale—a ubiquitous super source rock? In: 1996 New Zealand Petroleum Conference proceedings. Pp. 12-21. Ministry of Commerce, Wellington, New Zealand.

Killops, S.D, Cook, R.A., Sykes, R., Boudou, J.P. 1997. Petroleum potential and oil-source correlation in the Great South and Canterbury Basins. New Zealand Journal of Geology and Geophysics 40, 405-423.

Dylan Meadows, 2009. 
References

Killops, S.D., Hollis, C.J., Morgans, H.E.G., Sutherland, R., Field, B.D., Leckie, D.A. 2000. Paleoceanographic significance of Late Paleocene dysaerobia at the shelf/slope break around New Zealand. Palaeogeography, Palaeoclimatology, Palaeoecology 156, 51-70.

King, P.R., Thrasher, G.P. 1996. Cretaceous and Cenozoic Sedimentary Geology of the Taranaki Basin, New Zealand. IGNS Monograph 13, Institute of Geological and Nuclear Sciences, Lower Hutt, New Zealand.

Kurtz, A.C., Kump, L.R., Arthur, M.A., Zachos, J.C., Payton, A. 2003. Early Cenozoic decoupling of the global carbon and sulfur cycles. Paleoceanography 18(4), 1090.

Leckie, D.A., Morgans, H.E.G., Wilson, G.J., Uruski, C.I. 1992. Stratigraphic Framework and source-rock potential of Maastrichtian to Paleocene marine shale, East Coast, North Island, New Zealand: Hydrocarbon Prospects. Institute of Geological and Nuclear Sciences Science Report 92/5.

Leckie, D.A., Morgans, H., Wilson, G., Edwards, A.R. 1995. Mid-Paleocene dropstones in the Whangai Formation, New Zealand - evidence of mid-Paleocene cold climate? Sedimentary Geology 97, 119-129.

Meadows, D.J. 2008. Geochemistry of the Paleocene Tartan Formation in the Great South Basin, New Zealand. Unpublished Graduate Diploma of Science. Victoria University of Wellington, New Zealand.

Meyers, P.A. 1989. Sources and deposition of organic matter in Cretaceous passive margin deep-sea sediments: a synthesis of organic geochemical studies from Deep Sea Drilling Project Site 603, outer Hatteras Rise. Marine and Petroleum Geology 6, 182-189.

Meyers, P.A. 1992. Organic matter variations in sediments from DSDP sites 362 and 532: Evidence of upwelling changes associated with the Benguela Current. In: Summerhayes, C.P., Prell, W.L., Emis, K.C. (Editors), Evolution of Upwelling Systems Since the Early Miocene. The Geology Society, Bath, pp. 323-329.

Meyers, P.A. 1994. Preservation of elemental and isotopic source identification of sedimentary organic matter. Chemical Geology 114, 289-302.

Meyers, P.A. 1997. Organic geochemical proxies of paleoceanographic, paleolimnologic, and paleoclimatic processes. Organic Geochemistry 27, 213-250.

Meyers, P.A., Bernasconi, S.M., Forster, A. 2006. Origins and accumulation of organic matter in expanded Albian to Santonian black shale sequences on the Demerara Rise, South American margin. Organic Geochemistry 37, 1816-1830.

Milne, A.D. 1975. Resolution-1 Well Completion Report. Petroleum Report 648. Crown Minerals, Ministry of Economic Development, New Zealand. 
References

Moore, P.R. 1986a. A revised Cretaceous-Early Tertiary stratigraphic nomenclature for eastern North Island, New Zealand. New Zealand Geological Survey Report G104, Institute of Geological and Nuclear Sciences, Lower Hutt, New Zealand.

Moore, P.R., Snowdon, L.R., Osadetz, K.G. 1987. Maturation and petroleum source rock potential of the Whangai and Waipawa formations (Late Cretaceous-Paleocene), eastern North Island. New Zealand Geological Survey record 20: 17-23.

Moore, P.R. 1988b. Stratigraphy, composition and environment of deposition of the Whangai Formation and associated Late Cretaceous-Paleocene rocks, eastern North Island, New Zealand. New Zealand Geological Survey Bulletin 100.

Moore, P.R. 1989. Stratigraphy of the Waipawa Black Shale (Paleocene), eastern North Island, New Zealand. New Zealand Geological Survey Record G38, Institute of Geological and Nuclear Sciences, Lower Hutt, New Zealand.

Mound, D.G., Pratt, D.N. 1984. Interpretation of PPL 38202 Canterbury Basin, New Zealand. Petroleum Report 1021. Crown Minerals, Ministry of Economic Development, New Zealand.

Mutter, J.C., Hegarty, K.A., Cande, S.C., Weissel, J.K. 1985. Breakup between Australia and Antarctica: a brief review in light of new data. Tectonophysics 114: 255-279.

Nathan, S. 1976. Cretaceous and Lower Tertiary stratigraphy of the coastal strip between Buttress Point and Ship Creek, South Westland, New Zealand. New Zealand Journal of Geology and Geophysics 20, 615-654.

Olson, R.K. 1996. New Zealand Great South Basin, Block PEP 38210. Petroleum Report 2270. Crown Minerals, Ministry of Economic Development, New Zealand.

Osborne, C.P., Beerling, D.J. 2006. Nature's green revolution: the remarkable evolutionary rise of $\mathrm{C}_{4}$ plants. Philosophical Transactions of the Royal Society B: Biological Sciences 361 , 173-194.

Placid Oil Co. 1984a. Final geological well completion report, Pukaki-1, Great South Basin, New Zealand. Petroleum Report 1005. Crown Minerals, Ministry of Economic Development, New Zealand.

Placid Oil Co. 1984b. Final geological well completion report, Rakiura-1, Great South Basin, New Zealand. Petroleum Report 994. Crown Minerals, Ministry of Economic Development, New Zealand.

Raine, J.I., Strong, C.P., Wilson, G.J. 1993. Biostratigraphic revision of petroleum exploration wells, Great South Basin, New Zealand. IGNS Science Report 93/32, Institute of Geological and Nuclear Sciences, Lower Hutt, New Zealand.

Dylan Meadows, 2009. 
References

Raine, J.I., Strong, C.P., Wilson, G.J., Pocknall, D.T. 1994. Biostratigraphic revision of petroleum exploration wells, Great South Basin, New Zealand. IGNS Science Report 94/30, Institute of Geological and Nuclear Sciences, Lower Hutt, New Zealand.

Rau, G.H., Arthur, M.A., Dean, W.E. $1987 .{ }^{15} \mathrm{~N} /{ }^{14} \mathrm{~N}$ variations in Cretaceous Atlantic sedimentary sequences; implication for past changes in marine nitrogen biogeochemistry. Earth and Planetary Science Letters 82, 269-279.

Rogers, K.M, Morgans, H.E, Wilson, G.S. 2001. Identification of a Waipawa Formation equivalent in the upper Te Uri Member of the Whangai Formation: implications for depositional history and age. New Zealand Journal of Geology and Geophysics 44, 347-354.

Schioler, P., Roncaglia, L. 2008. Age and depositional environment of the Tartan Formation, a potential source rock in the Great South Basin. In: 2008 New Zealand Petroleum Conference Proceedings, Crown Minerals, Ministry of Economic Development, New Zealand.

Schoell, M., McCaffrey, M.A., Fago, F.J., Moldowan, J.M. 1992. Carbon isotopic composition of 28,30-bisnorhopanes and other biological markers in a Monterey crude oil. Geochimica et Cosmochimica Acta 56, 1391-1399.

Shell BP Todd. 1984. Interpretation and prospectivity of PPL 38203 Canterbury Basin, New Zealand. Petroleum Report 1046. Crown Minerals, Ministry of Economic Development, New Zealand.

Simpson, J. 1993. Review of the geochemistry of lower Kaitiki and Clipper formations in Endeavour-1 and the biostratigraphy of the Cretaceous to Eocene section in Clipper1: Implications for the petroleum geology of the Canterbury Basin. Petroleum Report 1997. Crown Minerals, Ministry of Economic Development, New Zealand.

Stott, L.D., Kennett, J.P. 1990. The paleoceonographic and paleoclimatic signature of the Cretaceous/Paleogene boundary in the Antarctic: stable isotopic results from ODP Leg 113. In: Barker, P.F., Kennett, J.P. (Editors), Proceedings of the Ocean Drilling Program, Scientific Results, College Station, Texas. 113, 829-848.

Stott, L.D., Sinha, A., Thiry, M., Aubry, M., Berggren, W.A. 1996. Global $\delta^{13} \mathrm{C}$ changes across the Paleocene-Eocene boundary: criteria for terrestrial-marine correlations. Geological Society London Special Publication 101, 381-399.

Strong, C.P., Hollis, C.J., Wilson, G.J. 1995. Foraminiferal, radiolarian and dinoflagellate biostratigraphy of Late Cretaceous to Middle Eocene pelagic sediments (Muzzel Group). New Zealand Journal of Geology and Geophysics 38, 171-212.

Tissot, B.P., Welte, D.H. 1978. Petroleum Formation and Occurrence: A New Approach to Oil and Gas Exploration. Berlin: Springer-Verlag. 538pp.

Dylan Meadows, 2009. 
References

Thomas, E. 1990. Late Cretaceous through Neogene deep-sea benthic foraminifers (Maud rise, Weddell Sea, Antarctica). In: Barker, P.F., Kennett, J.P. (Editors), Proceedings of the Ocean Drilling Program, Scientific Results, College Station, Texas. 113, 571-594.

Twichell, S.C., Meyers, P.A., Diester-Haass, L. 2002. Significance of high C/N ratios in organic-carbon-rich Neogene sediments under the Benguela Current upwelling system. Organic Geochemistry 33, 715-722.

van Mooy, B.A.S., Keil, R.G., Devol, A.H. 2002. Impact of suboxia on sinking particulate organic carbon: enhanced carbon flux and preferential degradation of amino acids via denitrification. Geochimica et Cosmochimica Acta 66, 457-465.

Veevers, J.J. 1986. Breakup of Australia and Antarctica estimated as mid-Cretaceous $(95 \pm 5$ $\mathrm{Ma})$ from magnetic and seismic data at the continental margin. Earth and Planetary Science Letters 77, 91-99.

Verardo, D.J., MacIntyre, A. 1994. Production and preservation: control of biogenous sedimentation in the tropical Atlantic 0-300,000 years B.P. Paleoceanography 9, 63-86.

Waples, D.W., Machihara, T. 1991. Biomarkers for Geologists: a practical guide to the application of steranes and triterpanes in petroleum geology. American Association of Petroleum Geologists, Methods in Exploration Series 9: 91pp.

White, W.M. 2001. Stable Isotope Geochemistry. In: White, W.M (Editor), Geochemistry. pp. 363-413. Accessible online at http://www.imwa.info/geochemistry/

Wilding, A., Sweetman, L.A.D. 1971. Endeavour-1 Well Completion Report. Petroleum Report 303. Crown Minerals, Ministry of Economic Development, New Zealand.

Wilson, G.J., 1984. New Zealand Late Jurassic to Eocene dinoflagellate biostratigraphy—a summary. Newslett. Stratigraphy 13, 104-117.

Wilson, I.R. 1985. Galleon-1 Well Completion Report. Petroleum Report 1146. Crown Minerals, Ministry of Economic Development, New Zealand.

Wilson, G.J., McMillan, S.G. 1996. Late Cretaceous-Tertiary Stratigraphic sections of Coastal Otago, South Island New Zealand: a summary of biostratigraphic and lithostratigraphic data. IGNS Science Report 96/39, Institute of Geological and Nuclear Sciences, Lower Hutt, New Zealand.

Zachos, J.C., Lohmann, K.C., Walker, J.C.G., Wise, S.W. 1993. Abrupt climate change and transient climates during the Paleogene: a marine perspective. Journal of Geology 101, 191-213.

Zachos, J.C., Pagani, M., Sloan, L., Thomas, E., Billups, K. 2001. Trends, Rhythms, and Aberrations in global climate $65 \mathrm{Ma}$ to present. Science 292, 686-693.

Dylan Meadows, 2009. 
Appendices

Dylan Meadows, 2009. 


\section{Appendix 1}

\begin{tabular}{|c|c|c|c|c|c|c|c|}
\hline \multicolumn{3}{|c|}{ INTERNATIONAL } & \multicolumn{5}{|c|}{ NEW ZEALAND } \\
\hline Era & Period & Epoch & Series & Stage & $\begin{array}{l}\text { Dे } \\
\text { हैं } \\
\text { है }\end{array}$ & $\begin{array}{c}\text { Age of } \\
\text { base } \\
\text { (Ma) }\end{array}$ & $\begin{array}{c}\text { Duration } \\
\text { (Ma) }\end{array}$ \\
\hline \multirow{24}{*}{ 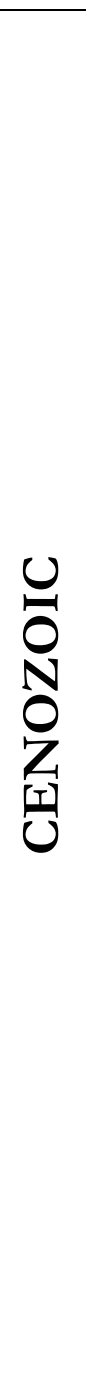 } & \multirow{3}{*}{ Quaternary } & Holocene & \multirow{6}{*}{ Wanganui Series } & Haweran & Wq & 0.34 & 0.34 \\
\hline & & Pleistocene & & Castlecliffian & Wc & 1.63 & 1.29 \\
\hline & & & & Nukumaruan & $\mathrm{Wn}$ & 2.4 & 0.77 \\
\hline & \multirow{11}{*}{ Neogene } & \multirow[t]{3}{*}{ Pliocene } & & Mangapanian & $\begin{array}{l}\text { W } \\
\mathrm{m}\end{array}$ & 3.03 & 0.63 \\
\hline & & & & Waipipian & $\mathrm{Wp}$ & 3.6 & 0.57 \\
\hline & & & & Opoitian & Wo & 5.28 & 1.68 \\
\hline & & \multirow{8}{*}{ Miocene } & \multirow{2}{*}{ Taranaki Series } & Kapitean & $\mathrm{Tk}$ & 6.5 & 1.22 \\
\hline & & & & Tongaporutuan & $\mathrm{Tt}$ & 11.0 & 4.5 \\
\hline & & & \multirow{3}{*}{ Southland Series } & Waiauan & $\mathrm{Sw}$ & 13.2 & 2.2 \\
\hline & & & & Lillburnian & $\mathrm{Sl}$ & 15.1 & 1.9 \\
\hline & & & & Clifdenian & Sc & 16.0 & 0.9 \\
\hline & & & \multirow{2}{*}{ Pareora Series } & Altonian & $\mathrm{Pl}$ & 19.0 & 3 \\
\hline & & & & Otaian & Po & 21.7 & 2.7 \\
\hline & & & \multirow{3}{*}{ Landon Series } & Waitakian & $\mathrm{Lw}$ & 25.2 & 3.5 \\
\hline & \multirow{10}{*}{ Paleogene } & \multirow[t]{2}{*}{ Oligocene } & & Duntroonian & $\mathrm{Ld}$ & 27.3 & 2.1 \\
\hline & & & & Whaingaroan & $\begin{array}{c}\mathrm{Lw} \\
\mathrm{h}\end{array}$ & 34.3 & 7 \\
\hline & & \multirow{7}{*}{ Eocene } & & Runangan & $\mathrm{Ar}$ & 35.8 & 1.5 \\
\hline & & & Arnold Series & Kaiatan & $\mathrm{Ak}$ & 37.0 & 1.2 \\
\hline & & & & Bortonian & $\mathrm{Ab}$ & 43.0 & 6 \\
\hline & & & & Porangan & $\mathrm{Dp}$ & 46.2 & 3.2 \\
\hline & & & & Heretaungan & $\mathrm{Dh}$ & 49.5 & 3.3 \\
\hline & & & Dannevirke & Mangaorapan & $\mathrm{Dm}$ & 53.0 & 3.5 \\
\hline & & & Series & Waipawan & Dw & 55.5 & 2.5 \\
\hline & & Paleocene & & Teurian & $\mathrm{Dt}$ & 65.0 & 9.5 \\
\hline & & & Mato Seriec & Haumurian & $\mathrm{Mh}$ & 84.5 & 19.5 \\
\hline & & & & Piripauan & $\mathrm{Mp}$ & 86.5 & 2 \\
\hline 긍 & & & & Teratan & Rt & 89.0 & 2.5 \\
\hline $\mathbf{N}$ & & & Raukumara Series & Mangaotanean & $\mathrm{Rm}$ & 92.0 & 3 \\
\hline 0 & Cretaceous & & & Arowhanan & $\mathrm{Ra}$ & 95.0 & 3 \\
\hline $\cot _{0}$ & & & & Ngaterian & $\mathrm{Cn}$ & 100.0 & 5 \\
\hline 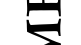 & & & Clarence Series & Motuan & $\mathrm{Cm}$ & 103.0 & 3 \\
\hline & & & & Urutawan & $\mathrm{Cu}$ & 108.0 & 5 \\
\hline & & & Taitai Series & (Korangan) & Uk & (117) & 9 \\
\hline
\end{tabular}

International and New Zealand Geochronological Timescales. Modified from Geological and Nuclear Sciences (2003).

Dylan Meadows, 2009. 
Dylan Meadows, 2009. 
Dylan Meadows, 2009. 


\section{Appendix 2}

\section{Biostratigraphy of the Tartan Formation in Canterbury and Great South basin wells}

Resolution - 1

The following is a brief summary of the biostratigraphy of Paleocene and Eocene strata in Resolution-1 as described by Hornibrook et al. (1975) in Milne (1975).

The interval between $1380 \mathrm{~m}$ and $1415 \mathrm{~m}$ is characterised by a mid-Eocene (Bortonian, Ab) microfauna.

The Bortonian index foraminiferan species, Gaudryina proreussi, appears in cuttings from $1380-85 \mathrm{~m}$, and is common in later cuttings samples. The Bortonian species, Plectina aggrestior, is present in cuttings from 1400-05 $\mathrm{m}$ and 1410-15 $\mathrm{m}$ (together with Marginulinopsis spinobesa).

Between $1396 \mathrm{~m}$ and $1415 \mathrm{~m}$, the Lower Bortonian form, Eunvigerina wanzea, is present. The interval $1415 \mathrm{~m}$ to $1465 \mathrm{~m}$ contains some Bortonian foraminifera which are present due to cavings in cuttings samples. Hornibrook et al. (1975) stated that the appearance of Elphidium hampdenense in the cuttings sample from $1410-15 \mathrm{~m}$ is a definite indicator of Heretaungan age. This form is also present in sidewall cores from $1428 \mathrm{~m}$ and $1443 \mathrm{~m}$. Another species present in the sidewall core from $1443 \mathrm{~m}$ is Globorotalia crater, which is a Heretaungan (Dh) to Mangaorapan (Dm) species.

The interval from $1465 \mathrm{~m}$ to $1490 \mathrm{~m}$ was analysed from one sidewall core sample from $1474.5 \mathrm{~m}$. This sample contained a shallow water assemblage of agglutinated foraminifera. The interval was assigned a Teurian age based on the appearance of Bolivinopsis compta and Bolivinopsis spectabilis.

Palynological analyses of the sidewall core sample from 1478 m identified Nothofagus waipawaenesis and Triorites minor. T. minor is considered to be more frequent in the Dannevirke Series than in the Haumurian Series, while Nothofagus waipawaenesis is regarded as a Teurian index species (Hornibrook et al. 1975).

\section{Endeavour - 1}

The following description of the biostratigraphy of Endeavour-1 focuses on Paleocene and Eocene strata as discussed by Wilding and Sweetman (1971). 
The interval between $1494 \mathrm{~m}$ and $1576 \mathrm{~m}$ has been assigned a Heretaungan age based on the appearance of Elphidium hampdenensis, which is considered to be a typical Heretaungan marker, and is common throughout this interval. Other species of the Dannevirke Series common within this interval include Vaginulinopsis marshalli and Nuttallides carinotrumpyi.

Planktonic species that appear for the first time within this interval are Globigerina triloculinoides and Globorotalia aequa rex. Benthonic species appearing for the first time within this interval include Buliminella browni, which is associated with the Waipawan to Heretaungan, and Bulimina subbortonica.

Elphidium hampdenensis is not found between samples from $1576 \mathrm{~m}$ to $1615 \mathrm{~m}$. Its absence here and lower downhole has been used as an indicator for the top of the Mangaorapan Stage (Wilding and Sweetman, 1971).

Faunas within the interval $1615 \mathrm{~m}$ and $1975 \mathrm{~m}$ are dominated by Haplophragmoides spp. and Trochammina spp. Other species commonly found include Cyclammina elegans, Bolivinopsis compta, Karrerulina aegra, and Thalmannammina subturbinata. There is a lack of prominent forms that clearly indicate the boundary between the Waipawan and the Teurian (Wilding and Sweetman, 1971).

Palynological analyses of samples between $1719 \mathrm{~m}$ and $1734 \mathrm{~m}$ show the first appearances of Proteacidites hakeoides, and P. annularis, both of which are known to first appear in the Waipawan. Between these samples, the Teurian species Clavifera triplex and Nothofagidites waipawaensis disappear from the fossil record. Based upon this information the WaipawanTeurian boundary is inferred to lie between these two samples (Wilding and Sweetman, 1971).

The sample from $1737 \mathrm{~m}$ has been found to contain several species, all of which indicate an age no older than Teurian. These species include Nothofagidites waipawaensis, Tricolpites secarius and Engelhardtioidites minisculus.

\section{Galleon - 1}

The following is a brief summary of the biostratigraphy of Paleocene and Eocene strata in Galleon-1 as described by Gibbons and Fry (1986).

Dannevirke Series strata (Porangan to Teurian) in Galleon-1 are present from a depth of $1914.6 \mathrm{~m}$ to $2675 \mathrm{~m}$. 
The characteristic Porangan (Dp) Globigerina boweri Biozone is represented at $1914.5 \mathrm{~m}$. The interval between $1950 \mathrm{~m}$ and $2595 \mathrm{~m}$ is dominated by agglutinated foraminifera. The upper part of this interval (down to $2320.8 \mathrm{~m}$ ) is believed to be of Heretaungan age (Dh). Below this, to around $2402 \mathrm{~m}$, the age is thought to be Mangaorapan (Dm) to Waipawan (Dw). Poor and sparse faunal assemblages limit accurate distinction of the Dm-Dw boundary (Gibbons and Fry, 1986).

Palynological analyses of the sample from $2402 \mathrm{~m}$ constrain the Apectodinium homomorphum Biozone to the Early Waipawan (and possibly Late Teurian) at this depth.

The Teurian Stage is represented from $2474.6 \mathrm{~m}$ to $2675 \mathrm{~m}$ in this well. Palynological evidence places the Palaeocystodinium australinum Biozone, which is characteristically of Teurian age, between $2474.6 \mathrm{~m}$ and $2624 \mathrm{~m}$.

The Bolivinopsis spectabilis Biozone is represented between $2603 \mathrm{~m}$ and $2624 \mathrm{~m}$. Hornibrook (1968) stated that the presence of Bolivinopsis spectabilis indicated an age no younger than Teurian. There are some foraminiferal forms present that Moore (1988b) suggested are characteristic forms commonly identified with the Waipawa Formation, such as Bathysiphon sp. The occurrence of Globigerina triloculinoides within this biozone suggests an age of Teurian (Dt) to Waipawan (Dw), or possibly Heretaungan (Dh). This interval differs from the overlying Agglutinate Interval in the presence of Bolivinopsis spectabilis, Buliminella creta, Conotrochammina whangaia, and also the reduced abundance and diversity of species.

Below the Bolivinopsis spectabilis Biozone is the Globigerina pauciloculata Biozone (2672 m). This interval differs from the overlying Bolivinopsis spectabilis Biozone in the presence of Globigerina pauciloculata (Gibbons and Fry, 1986).

\section{Clipper- 1}

A description of the biostratigraphy of Dannevirke Series strata in Clipper-1, as written by Crux et al. (1984), is summarised below.

The Porangan Stage (Dp) is represented between $2410 \mathrm{~m}$ and $2460 \mathrm{~m}$ in Clipper-1. The sidewall core from $2410 \mathrm{~m}$ contains Globigerapsis index and Globigerina frontosa boweri, which is indicative of a Porangan age. Benthonic foraminifera in this sample include Bulimina subortonica, which is a known Dannevirke species around New Zealand (Crux et al. 1984).

The sample from $2455 \mathrm{~m}$ contains Elphidium saginatum, a benthonic index for the Porangan. The presence of the nannofossils Cyclococcolithus formosus and Reticulofenestra umbilica 
at $2410 \mathrm{~m}$ suggests an age of no lower than mid-Eocene, as internationally these species do not range below the mid-Eocene.

The Mangaorapan Stage is present from $2460 \mathrm{~m}$ to approximately $2560 \mathrm{~m}$. The occurrence of the nannofossil Chiasmolithus biden, at $2460 \mathrm{~m}$ indicates an Early Eocene to Paleocene age, with Eocene confirmed by the co-occurrence of the Eocene restricted species, Neococcolithes dubius. Foraminiferal assemblages within this interval contain a mixture of agglutinated and calcareous benthonic forms. No planktonic index taxa are present; however, a Mangaorapan age to $2540 \mathrm{~m}$ is confirmed by the presence of Vaginulinopsis marshalli (Crux et al. 1984).

The interval between $2560 \mathrm{~m}$ and $2694.5 \mathrm{~m}$ did not yield age diagnostic taxa; however, based upon evidence from above and below this interval, an age of Mangaorapan to Waipawan is inferred.

The interval between $2694.5 \mathrm{~m}$ and $2790 \mathrm{~m}$ is believed to be of Early Waipawan to Late Teurian age. The top of this interval is characterised by the first downhole appearance of the dinoflagellete cyst genus Apectodinium, including A. homomorphum in the sidewall core from $2694.5 \mathrm{~m}$. This species is associated with the Waipawan-Teurian boundary, with a bias towards the Teurian (Wilson, 1984).

The Teurian Stage is represented from $2790 \mathrm{~m}$ to $3175 \mathrm{~m}$. A cuttings sample from $2790 \mathrm{~m}$ contains an abundant, low diversity, agglutinated microfauna which comprises common deformed Haplophragmoides sp., Cyclammina grangeri, and Karreriella sp. Hornibrook (1968) has described a similar assemblage from the Teurian. The first downhole occurrence of the benthonic form, Gaudryina whangia, at $2895 \mathrm{~m}$ confirms a Teurian age.

The sidewall core at $2800 \mathrm{~m}$ contains the first downhole occurrence of the dinoflagellete cyst genus Palaeocystodinium, which is persistent from this depth, and includes forms close to P. australinum. Wilson (1984) stated that this species has an age that is no younger than Teurian around New Zealand. Wilson (1984) also recorded the same upper range limit for Palaeoperidinium pyrophorum, which appears for the first time at $3100 \mathrm{~m}$.

The first appearance of Trithyrodinium evittii at 3150 m suggests an Early Paleocene age, whilst the appearance of Isabelidinium druggii at $3175 \mathrm{~m}$ indicates an earliest Teurian age. Isabelidinium druggii is associated with the Cretaceous-Tertiary boundary in New Zealand (Crux et al. 1984). 
Rakiura - 1

The following is a brief summary of the biostratigraphy of Teurian to Waipawan strata in Rakiura-1 as described by Raine et al. (1993).

Teurian strata in this well are present from a depth of $1660 \mathrm{~m}$ to 2167 (?) $\mathrm{m}$, followed by Waipawan strata from $1560 \mathrm{~m}$ to $1660 \mathrm{~m}$. Moderate to poor foraminiferal faunas were commonly recovered from lower Dannevirke strata (Teurian to Waipawan). Cuttings samples of mid-Late Teurian age contain tentatively identified Cibicides hampdenensis (Dw-Ak). Lower Teurian samples are barren to sparsely fossiliferous, with only agglutinated assemblages present, of which, benthic taxa dominate. Budashevaella multicamerata (Mh-Dt) is the principle species to indicate ages in this interval. Cyclammina amplectans (Dt-Ar) is also present and is the only other species with a reasonably well known range identified from this interval.

Dinoflagellate assemblages from a sample taken from $1755.6 \mathrm{~m}$ include Palaeocystodinium golzowense, Spiniferites septatus (Dt-Dh) and Cerodinium cf. medcalfii, which tend to indicate the $P$. golzowense Zone (Teurian age). Based on the presence of Palaeoperidinium pyrophorum, Cerodinium speciosum, Spiniferites septatus (Dt-Dh), and Palambages cf. morulosa from the sample taken from $1737.4 \mathrm{~m}$, the apparent age is Teurian.

The Waipawan/Teurian boundary was placed midway between samples dated by dinoflagellates at $1591.1 \mathrm{~m}$ and $1737.4 \mathrm{~m}$ (Raine et al. 1993).

\section{Pukaki- 1}

Schioler and Roncaglia (2008) recognised the top of the Tartan Formation in this well to be at a depth of $2297.5 \mathrm{~m}$ and the base at $2316.2 \mathrm{~m}$. Raine et al. (1993) stated that the Teurian Stage (Dt) occurs between 2400(?)-2790 m, followed by an unconformity or condensed interval between 2350-2450 m (the interval was defined by $2350 \mathrm{~m}$ being the lowest Porangan sample and $2450 \mathrm{~m}$ being the highest likely Teurian sample). Overlying the $2350 \mathrm{~m}$ sample are strata of Porangan (Dp) age [1825-2400(?) m].

Due to the possibility that an unconformity is present between Porangan and Teurian strata, it is conceivable that several hundred meters of strata may have been eroded. No fossil evidence is present in this $2350 \mathrm{~m}$ to $2450 \mathrm{~m}$ interval to indicate the presence of the Heretaungan (Dh), Mangaorapan (Dm) or Waipawan stages (Dw) (Raine et al. 1993). If there 
is an unconformity due to erosion within this interval, it is probable that any fossil record from these stages would have been removed during the erosive event.

Comparison of data from both Schioler and Roncaglia (2008) and Raine et al. (1993) suggests that the Tartan Formation was deposited between the latest Teurian and the earliest Porangan. More accurate constraints on the age of the Tartan Formation in this well are not possible based on current knowledge.

Teurian foraminifera identified by Raine et al. (1993) include Bolivinopsis spectabilis, Haplophragmoides cf. teuria, H. sp., and Thalmannammina sp. Faunas recovered that are likely to be of latest Teurian age were of poor quality and consisted entirely of agglutinated taxa.

The biostratigraphy and age of the Tartan Formation from exploration wells examined by Meadows (2008) are also included here.

\section{Toroa -1}

The top of the Tartan Formation in the Toroa-1 petroleum exploration well was reported to be at $2137 \mathrm{~m}$ and the base at $2200 \mathrm{~m}$ by Cook et al. (1999). This implies that most of the Tartan Formation was deposited during the Late Teurian with a small portion having been deposited during the earliest Waipawan Stage. The Teurian interval occurs between $2150 \mathrm{~m}-$ $2863 \mathrm{~m}$ and the Waipawan interval between $1350 \mathrm{~m}-2150 \mathrm{~m}$ in Toroa-1 (Raine et al. 1993).

A sidewall core from $2206.8 \mathrm{~m}$, approximately the depth that Cook et al. (1999) give as the base of the Tartan Formation, shows a moderately rich dinoflagellate assemblage with the first appearance of Palaeocystodinium golzowense, indicating the Late Teurian P. golzowense Zone. The same sidewall sample contains Phyllocladidites mawsonii-dominated assemblages of miospores, in which some restricted Cenozoic taxa, including Nothofagus waipawaensis (which is restricted to the Teurian), occur.

Palynofloras and foraminifera agree in giving a Teurian age at around $2200 \mathrm{~m}$, but above this level there is some doubt of the age, due to the occurence of the foraminifera Bolivinopsis spectabilis in a sidewall sample taken from $1847 \mathrm{~m}$. B. spectabilis is of Waipawan age, above the limits of the upper Teurian. The dinoflagellete Apectodinium homomorphum from $2094 \mathrm{~m}$ also suggests Waipawan age (Raine et al. 1993).

Cyclammina spp. is a characteristic Waipawa Black Shale species, and has been identified from about $2150 \mathrm{~m}$ through $2260 \mathrm{~m}$. Below $2260 \mathrm{~m}$, faunas are still dominated by a 
Cycalmmina-Budashevaella association, indicating a Late Teurian age, but there is a tendency for declining abundance (Raine et al. 1993).

\section{Pakaha- 1}

Cook et al. (1999) reported the top of the Tartan Formation in the Pakaha-1 petroleum exploration well to be at a depth of $2503 \mathrm{~m}$ and the base at a depth of $2551 \mathrm{~m}$. Raine et al. (1993) designated the interval $2055 \mathrm{~m}-2485 \mathrm{~m}$ to belong to the Waipawan Stage, while the Teurian Stage occurs between $2485 \mathrm{~m}$ and $3167 \mathrm{~m}$. Comparison of the data from both Cook et al. (1999) and Raine et al. (1993) shows that deposition of the Tartan Formation occurred during the latest Teurian.

A sidewall core from $2252 \mathrm{~m}$ contains a dinoflagellate-dominated palynoflora with an $A$. homomorphum or W. spinulosa Zone assemblage, of Early to mid-Waipawan age. Another sidewall sample from $2473 \mathrm{~m}$ was dated from nannofossils to be of upper Teurian to basal Waipawan age (Hornibrook and Edwards, 1977).

The approximate positioning of the top of the Teurian is suggested by the occurrence of the foraminifera Bolivinopsis spectabilis at $2463 \mathrm{~m}$. Bulimina kickapooensis, Alabamina creta and Anomalinoides piripana have the highest occurrence in the sidewall core from $2554 \mathrm{~m}$, and are considered to be more definitive species for the determination of the upper boundary of the Teurian Stage (Raine et al. 1993).

A sidewall core examining dinoflagellates from $2505 \mathrm{~m}$ contains fairly abundant Palaeocystodinium golzowense and rare Cassidium fragile, indicating Late Teurian.

Raine et al. (1993) stated that the Teurian/Waipawan boundary lies between sidewall samples at $2505 \mathrm{~m}$ and $2474 \mathrm{~m}$, with a depth of $2485 \mathrm{~m}$ being chosen to represent the boundary.

The upper Teurian is characterised by a Waipawa Black Shale lithofacies, primarily comprising agglutinated foraminiferal fauna typified by Budashevaella multicamerata and Cyclammina elegans, with minor calcareous benthics, in particular Bulimina kickapooensis and Alabamina creta (Raine et al. 1993).

Kawau - $1 A$

The top of the Tartan Formation as published by Cook et al. (1999) is at a depth of 2220 $\mathrm{m}$, while the base is reported to be $2264 \mathrm{~m}$. Raine et al. (1993) state that the Teurian interval 
is between $2140 \mathrm{~m}$ and $2850 \mathrm{~m}$. Thus the Tartan Formation in Kawau-1A is entirely of upper Teurian age.

The top of the Teurian was placed by Raine et al. (1993) at the highest occurrence of the foraminifera Cyclammina elegans, in a cutting sample taken from $2140 \mathrm{~m}$.

The foraminiferal fauna primarily consists of agglutinated forms. Principle taxa are Cyclammina elegans, Budashevaella multicamerata and Haplophragmoides sp. (Raine et al. 1993).

Hoibo- $1 C$

The top of the Tartan Formation in Hoiho-1C is placed at $1545 \mathrm{~m}$, while the base is at a depth of 1592 m (Cook et al. 1999). Raine et al. (1993) placed the Teurian Stage between $1545 \mathrm{~m}$ and $1735 \mathrm{~m}$. Thus the Tartan Formation here was deposited during the very latest Teurian. The top of the Teurian Stage is placed at the highest occurrence of Bolivinopsis spectabilis together with the tentatively identified Cyclammina elegans, in a fauna from a cuttings sample from $1545 \mathrm{~m}$. The highest occurrence of the typical Teurian foraminiferan Budashevaella multicamerata was identified in a cuttings sample from $1554 \mathrm{~m}$.

All samples are characterised by sparse to moderately abundant, low diversity assemblages consisting primarily or entirely of agglutinated taxa. No planktics were observed. Agglutinated taxa are dominated by Bolivinopsis, Cyclammina elegans, Budashevaella multicamerata, Haplophragmoides spp., and Karreriella aegra (Raine et al. 1993). 


\section{Appendix 3}

Full list of geochemical data from Meadows (2008) analyses

\begin{tabular}{ccccccc} 
Well & Depth(m) & Depth(ave) & $\boldsymbol{\delta}^{13} \mathbf{C}$ & TOC & \%N & C/N \\
\hline Takapu-1A & $485-94$ & 490 & -25.8 & 3.3 & 0.06 & 64 \\
Takapu-1A & $530-40$ & 535 & -26.7 & 1.1 & 0.04 & 31 \\
Takapu-1A & $585-95$ & 590 & -26.1 & 0.8 & 0.04 & 23 \\
Takapu-1A & $631-40$ & 636 & -27.8 & 1.4 & 0.05 & 33 \\
Takapu-1A & $686-95$ & 691 & -26.2 & 1.1 & 0.05 & 26 \\
Takapu-1A & $695-704$ & 700 & -26.4 & 1.1 & 0.05 & 26 \\
Takapu-1A & $704-13$ & 709 & -27 & 1.3 & 0.05 & 30 \\
Takapu-1A & $759-65$ & 762 & -25.6 & 2.3 & 0.06 & 45 \\
Takapu-1A & $805-14$ & 810 & -26.8 & 0.9 & 0.04 & 26 \\
Takapu-1A & $860-69$ & 865 & -25.2 & 1.4 & 0.03 & 54 \\
\hline Kawau-1A & $2030-2037$ & 2034 & -27 & 0.2 & 0.02 & 12 \\
Kawau-1A & $2076-2085$ & 2081 & -27.3 & 0.3 & 0.02 & 18 \\
Kawau-1A & $2140-2149$ & 2145 & -26.4 & 1.6 & 0.05 & 37 \\
Kawau-1A & $2177-2186$ & 2182 & -26.3 & 0.9 & 0.03 & 35 \\
Kawau-1A & $2232-2241$ & 2237 & -21.3 & 5 & 0.2 & 29 \\
Kawau-1A & $2241-2250$ & 2246 & -19.6 & 7.6 & 0.29 & 31 \\
Kawau-1A & $2250-2259$ & 2255 & -17.7 & 10.8 & 0.42 & 30 \\
Kawau-1A & $2259-2268$ & 2264 & -17.4 & 11 & 0.45 & 29 \\
Kawau-1A & $2268-2277$ & 2273 & -18.4 & 7.9 & 0.33 & 28 \\
Kawau-1A & $2277-2287$ & 2282 & -20.2 & 3.8 & 0.19 & 23 \\
Kawau-1A & $2287-2296$ & 2292 & -20.4 & 3.5 & 0.18 & 23 \\
Kawau-1A & 2302 & 2302 & -26 & 1.7 & 0.1 & 20 \\
Kawau-1A & 2357 & 2357 & -25.1 & 1.9 & 0.13 & 17 \\
Kawau-1A & $2405-2415$ & 2410 & -26.9 & 1.2 & 0.08 & 18 \\
Kawau-1A & $2451-2460$ & 2456 & -26.6 & 1.0 & 0.05 & 23 \\
Kawau-1A & $2506-2515$ & 2511 & -27.6 & 1.1 & 0.05 & 26 \\
\hline
\end{tabular}




\begin{tabular}{|c|c|c|c|c|c|c|}
\hline Kawau-1A & & 2107 & -27.9 & 1.0 & 0.03 & 39 \\
\hline Kawau-1A & \multirow{9}{*}{$\begin{array}{l}0 \\
\frac{8}{0} \\
\frac{\pi}{2} \\
\end{array}$} & 2180 & -26.6 & 0.8 & 0.03 & 31 \\
\hline Kawau-1A & & 2193 & -28.5 & 0.4 & 0.02 & 23 \\
\hline Kawau-1A & & 2201 & -25.6 & 0.7 & 0.03 & 27 \\
\hline Kawau-1A & & 2218 & -24.5 & 0.4 & 0.02 & 23 \\
\hline Kawau-1A & & 2240 & -18.2 & 9.3 & 0.38 & 29 \\
\hline Kawau-1A & & 2263 & -21.4 & 4.7 & 0.19 & 29 \\
\hline Kawau-1A & & 2301 & -27.3 & 1.2 & 0.05 & 28 \\
\hline Kawau-1A & & 2376 & -27.6 & 1.3 & 0.05 & 30 \\
\hline Kawau-1A & & 2387 & -27.2 & 1.3 & 0.20 & 8 \\
\hline Hoiho-1 & \multirow{8}{*}{ 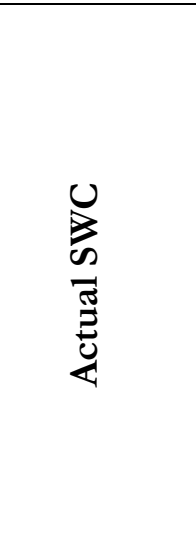 } & 1524 & -27.1 & 0.6 & 0.02 & 35 \\
\hline Hoiho-1 & & 1536 & -26.6 & 1.5 & 0.05 & 35 \\
\hline Hoiho-1 & & 1554 & -26.3 & 0.5 & 0.02 & 29 \\
\hline Hoiho-1 & & 1558 & -25 & 3 & 0.1 & 35 \\
\hline Hoiho-1 & & 1578 & -15.8 & 17.1 & 0.45 & 44 \\
\hline Hoiho-1 & & 1582 & -19.7 & 8 & 0.26 & 36 \\
\hline Hoiho-1 & & 1614 & -26.6 & 1.3 & 0.06 & 25 \\
\hline Hoiho-1 & & 1646 & -26.4 & 0.7 & 0.02 & 41 \\
\hline Pakaha-1 & $2372-81$ & 2377 & -23.6 & 1.9 & 0.07 & 32 \\
\hline Pakaha-1 & $2473-82$ & 2478 & -25.5 & 1.5 & 0.08 & 22 \\
\hline Pakaha-1 & $2491-2500$ & 2496 & -26.4 & 0.7 & 0.07 & 12 \\
\hline Pakaha-1 & $2546-55$ & 2551 & -19.3 & 6.5 & 0.31 & 24 \\
\hline Pakaha-1 & $2555-64$ & 2560 & -19.7 & 5.9 & 0.33 & 21 \\
\hline Pakaha-1 & 2701-10 & 2706 & -26.1 & 1.4 & 0.14 & 12 \\
\hline Pakaha-1 & $2756-65$ & 2761 & -26.8 & 0.9 & 0.09 & 12 \\
\hline Pakaha-1 & $2802-11$ & 2807 & -25.8 & 1.2 & 0.1 & 14 \\
\hline Pakaha-1 & \multirow{4}{*}{ 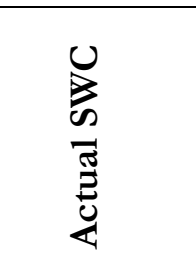 } & 2253 & -27.9 & 0.4 & 0.04 & 11 \\
\hline Pakaha-1 & & 2474 & -27.7 & 0.4 & 0.05 & 10 \\
\hline Pakaha-1 & & 2505 & -26.4 & 1.1 & 0.09 & 14 \\
\hline Pakaha-1 & & 2576 & -20.7 & 5.3 & 0.29 & 21 \\
\hline
\end{tabular}




\begin{tabular}{ccccccc} 
Pakaha-1 & & 2639 & -25.9 & 1.5 & 0.12 & 15 \\
Pakaha-1 & & 2659 & -27.0 & 1.6 & 0.15 & 12 \\
Pakaha-1 & & 2838 & -26.0 & 1.5 & 0.13 & 13 \\
\hline Toroa-1 & $1957-66$ & 1962 & -27.3 & 0.5 & 0.02 & 29 \\
Toroa-1 & $2012-21$ & 2017 & -26.9 & 0.4 & 0.02 & 20 \\
Toroa-1 & $2067-76$ & 2072 & -26.7 & 0.7 & 0.03 & 25 \\
Toroa-1 & $2113-22$ & 2118 & -26 & 1.0 & 0.04 & 28 \\
Toroa-1 & $2241-50$ & 2246 & -24.5 & 1.4 & 0.06 & 27 \\
Toroa-1 & $2341-51$ & 2346 & -26 & 0.2 & 0.01 & 27 \\
Toroa-1 & $2378-87$ & 2383 & -26.3 & 0.4 & 0.02 & 23 \\
Toroa-1 & $2433-42$ & 2438 & -27.4 & 0.3 & 0.01 & 30 \\
\hline Toroa-1 & & 2079 & -26.2 & 0.1 & 0.02 & 4 \\
Toroa-1 & & 2124 & -26.6 & 0.1 & 0.03 & 4 \\
Toroa-1 & & 2160 & -26.2 & 0.2 & 0.04 & 7 \\
Toroa-1 & \multirow{2}{*}{} & 2162 & -21 & 7.2 & 0.38 & 22 \\
Toroa-1 & \multirow{2}{*}{} & 2207 & -25.9 & 1.6 & 0.1 & 19 \\
Toroa-1 & \multirow{2}{*}{} & 2233 & -27 & 0.9 & 0.06 & 18 \\
Toroa-1 & & 2235 & -26.8 & 0.5 & 0.04 & 15 \\
Toroa-1 & & 2260 & -25.5 & 1.9 & 0.09 & 25 \\
\hline
\end{tabular}




\section{Appendix 4}

\section{Full list of geochemical data from the present study}

\begin{tabular}{|c|c|c|c|c|c|c|}
\hline Well & $\operatorname{Depth}(m)$ & Depth(Avg) & $d^{13} C$ & TOC & $\% \mathbf{N}$ & $\mathrm{C} / \mathrm{N}$ \\
\hline Rakiura-1 & $1683-92$ & 1688 & -26.1 & 0.4 & $<0.1$ & 23 \\
\hline Rakiura-1 & 1698-1701 & 1700 & -26 & 0.5 & $<0.1$ & 20 \\
\hline Rakiura-1 & $1720-29$ & 1725 & -25.9 & 0.5 & $<0.1$ & 18 \\
\hline Rakiura-1 & $1774-84$ & 1779 & -25.9 & 0.2 & $<0.1$ & 20 \\
\hline Rakiura-1 & 1784-93 & 1789 & -26.1 & 0.3 & $<0.1$ & 33 \\
\hline Rakiura-1 & 1793-1802 & 1798 & -25.8 & 0.2 & $<0.1$ & 26 \\
\hline Rakiura-1 & $1802-11$ & 1807 & -26.3 & 0.3 & $<0.1$ & 37 \\
\hline Rakiura-1 & $1811-20$ & 1816 & -25.8 & 0.1 & $<0.1$ & 15 \\
\hline Rakiura-1 & $1820-29$ & 1825 & -26.3 & 0.3 & $<0.1$ & 37 \\
\hline Rakiura-1 & 1829-39 & 1834 & -26.1 & 0.2 & $<0.1$ & 25 \\
\hline Rakiura-1 & $1838-48$ & 1843 & -26.2 & 0.5 & $<0.1$ & 27 \\
\hline Rakiura-1 & $1856-66$ & 1861 & -25.7 & 0.7 & $<0.1$ & 26 \\
\hline Rakiura-1 & 1884-93 & 1889 & -26.0 & 0.8 & $<0.1$ & 30 \\
\hline Rakiura-1 & 1963-65 & 1964 & -27.2 & 0.6 & $<0.1$ & 29 \\
\hline Pukakai-1 & $2274-83$ & 2279 & -26.3 & 0.3 & $<0.1$ & 32 \\
\hline Pukakai-1 & 2284-99 & 2292 & -25.8 & 0.3 & $<0.1$ & 23 \\
\hline Pukakai-1 & $2290-2300$ & 2295 & -26.3 & 1.1 & $<0.1$ & 56 \\
\hline Pukakai-1 & $2300-08$ & 2304 & -26.6 & 1.3 & $<0.1$ & 61 \\
\hline Pukakai-1 & $2308-17$ & 2313 & -18.7 & 3.9 & 0.1 & 36 \\
\hline Pukakai-1 & $2317-25$ & 2321 & -19.4 & 3.6 & 0.1 & 38 \\
\hline Pukakai-1 & $2325-35$ & 2330 & -19.7 & 3.4 & 0.1 & 38 \\
\hline Pukakai-1 & $2335-44$ & 2340 & -23.8 & 0.8 & $<0.1$ & 34 \\
\hline Pukakai-1 & $2381-90$ & 2386 & -23.5 & 0.9 & $<0.1$ & 34 \\
\hline Pukakai-1 & 2410-18 & 2414 & -23.6 & 0.8 & $<0.1$ & 33 \\
\hline Resolution-1 & \multirow{5}{*}{$\frac{u}{\frac{3}{6}}$} & 1396.5 & -27.0 & 0.4 & $<0.1$ & 15 \\
\hline Resolution-1 & & 1428 & -26.5 & 0.6 & $<0.1$ & 25 \\
\hline Resolution-1 & & 1462.5 & -24.5 & 0.3 & $<0.1$ & 13 \\
\hline Resolution-1 & & 1474.5 & -24.7 & 0.7 & $<0.1$ & 17 \\
\hline Resolution-1 & & 1478 & -23.9 & 1.6 & $<0.1$ & 32 \\
\hline Resolution-1 & $1380-85$ & 1383 & -25.74 & 0.3 & $<0.1$ & 20 \\
\hline Resolution-1 & $1405-10$ & 1408 & -25.18 & 0.3 & $<0.1$ & 30 \\
\hline Resolution-1 & $1420-25$ & 1423 & -25.14 & 0.3 & $<0.1$ & 40 \\
\hline Resolution-1 & $1430-35$ & 1433 & -25.63 & 0.6 & $<0.1$ & 36 \\
\hline Resolution-1 & $1440-45$ & 1443 & -25.77 & 0.7 & $<0.1$ & 27 \\
\hline
\end{tabular}




\begin{tabular}{|c|c|c|c|c|c|c|}
\hline Resolution-1 & $1450-55$ & 1453 & -26.14 & 1.3 & $<0.1$ & 39 \\
\hline Resolution-1 & $1465-70$ & 1468 & -26.56 & 0.7 & $<0.1$ & 20 \\
\hline Resolution-1 & $1475-80$ & 1478 & -25.88 & 0.8 & $<0.1$ & 31 \\
\hline Resolution-1 & $1490-95$ & 1493 & -25.89 & 0.8 & $<0.1$ & 23 \\
\hline Resolution-1 & $1500-10$ & 1505 & -25.6 & 0.9 & $<0.1$ & 27 \\
\hline Resolution-1 & $1520-30$ & 1525 & -25.5 & 0.7 & $<0.1$ & 21 \\
\hline Resolution-1 & $1550-60$ & 1555 & -26.12 & 0.7 & $<0.1$ & 20 \\
\hline Endeavour-1 & 1604-06 & 1605 & -25.5 & 0.7 & $<0.1$ & 18 \\
\hline Endeavour-1 & $1628-31$ & 1630 & -25.6 & 0.6 & $<0.1$ & 17 \\
\hline Endeavour-1 & $1652-55$ & 1654 & -26.0 & 0.8 & $<0.1$ & 20 \\
\hline Endeavour-1 & $1674-76$ & 1675 & -25.9 & 0.8 & $<0.1$ & 20 \\
\hline Endeavour-1 & $1692-95$ & 1694 & -25.4 & 0.8 & $<0.1$ & 18 \\
\hline Endeavour-1 & $1723-26$ & 1725 & -25.3 & 1.0 & $<0.1$ & 17 \\
\hline Endeavour-1 & $1729-32$ & 1731 & -21.5 & 2.1 & 0.1 & 22 \\
\hline Endeavour-1 & $1735-38$ & 1737 & -18.5 & 5.9 & 0.3 & 25 \\
\hline Endeavour-1 & $1744-47$ & 1746 & -19.5 & 4.2 & 0.2 & 23 \\
\hline Endeavour-1 & $1750-53$ & 1752 & -18.5 & 6.6 & 0.3 & 26 \\
\hline Endeavour-1 & $1762-65$ & 1764 & -19.7 & 4.6 & 0.2 & 25 \\
\hline Endeavour-1 & 1765-68 & 1766 & -21.3 & 2.5 & 0.1 & 22 \\
\hline Endeavour-1 & $1777-80$ & 1779 & -20.4 & 3.0 & 0.2 & 22 \\
\hline Endeavour-1 & $1793-96$ & 1795 & -23.9 & 1.5 & 0.1 & 16 \\
\hline Endeavour-1 & $1817-20$ & 1819 & -22.9 & 1.6 & 0.1 & 16 \\
\hline Endeavour-1 & $1820-23$ & 1822 & -23.9 & 0.9 & $<0.1$ & 12 \\
\hline Endeavour-1 & 1826-29 & 1828 & -21.9 & 2.4 & 0.1 & 23 \\
\hline Galleon-1 & $2455-60$ & 2458 & -25.7 & 1.2 & $<0.1$ & 19 \\
\hline Galleon-1 & $2470-75$ & 2473 & -25.5 & 1.4 & $<0.1$ & 21 \\
\hline Galleon-1 & $2485-90$ & 2488 & -25.5 & 1.2 & $<0.1$ & 20 \\
\hline Galleon-1 & $2500-05$ & 2503 & -24.1 & 1.1 & $<0.1$ & 19 \\
\hline Galleon-1 & $2510-15$ & 2513 & -19.0 & 5.6 & 0.2 & 30 \\
\hline Galleon-1 & $2515-20$ & 2518 & -19.6 & 4.5 & 0.2 & 29 \\
\hline Galleon-1 & $2520-25$ & 2523 & -23.3 & 2.0 & $<0.1$ & 26 \\
\hline Galleon-1 & $2525-30$ & 2528 & -24.5 & 1.5 & 0.1 & 24 \\
\hline Galleon-1 & $2530-35$ & 2533 & -22.9 & 1.8 & $<0.1$ & 26 \\
\hline Galleon-1 & $2535-40$ & 2538 & -24 & 1.4 & 0.1 & 21 \\
\hline Galleon-1 & $2545-50$ & 2548 & -25.8 & 1.1 & 0.1 & 20 \\
\hline Galleon-1 & $2555-58$ & 2557 & -26.4 & 1.0 & 0.1 & 23 \\
\hline Galleon-1 & 2564-67 & 2566 & -26 & 1.1 & 0.1 & 21 \\
\hline Galleon-1 & $2570-73$ & 2572 & -26 & 1.2 & 0.1 & 23 \\
\hline Galleon-1 & $2576-79$ & 2578 & -25.4 & 1.2 & $<0.1$ & 23 \\
\hline Galleon-1 & $2585-88$ & 2587 & -25.1 & 1.2 & 0.1 & 23 \\
\hline Galleon-1 & $2600-03$ & 2602 & -25.7 & 1.3 & 0.1 & 24 \\
\hline
\end{tabular}




\begin{tabular}{ccccccc} 
Galleon-1 & $2612-15$ & 2614 & -25.7 & 1.3 & 0.1 & 21 \\
Galleon-1 & $2624-27$ & 2626 & -24.7 & 1.1 & $<0.1$ & 24 \\
Galleon-1 & $2636-39$ & 2638 & -24.8 & 1.3 & 0.1 & 25 \\
\hline Clipper-1 & $2630-35$ & 2633 & -25.6 & 0.4 & $<0.1$ & 20 \\
Clipper-1 & $2680-85$ & 2683 & -24.6 & 1.0 & $<0.1$ & 36 \\
Clipper-1 & $2700-05$ & 2703 & -23.9 & 1.0 & $<0.1$ & 30 \\
Clipper-1 & $2710-15$ & 2713 & -21.6 & 0.9 & $<0.1$ & 37 \\
Clipper-1 & $2725-30$ & 2728 & -25.9 & 0.8 & $<0.1$ & 31 \\
Clipper-1 & $2750-55$ & 2753 & -25.4 & 0.9 & $<0.1$ & 29 \\
Clipper-1 & $2760-65$ & 2763 & -23.2 & 2.0 & 0.1 & 29 \\
Clipper-1 & $2765-70$ & 2768 & -20.6 & 2.5 & 0.1 & 30 \\
Clipper-1 & $2775-80$ & 2778 & -19.1 & 6.2 & 0.2 & 30 \\
Clipper-1 & $2780-85$ & 2783 & -19.2 & 6.8 & 0.3 & 30 \\
Clipper-1 & $2785-90$ & 2788 & -19.0 & 11.7 & 0.5 & 29 \\
Clipper-1 & $2790-95$ & 2793 & -19.5 & 7.1 & 0.3 & 29 \\
Clipper-1 & $2795-2800$ & 2798 & -20.1 & 4.6 & 0.2 & 30 \\
Clipper-1 & $2805-10$ & 2808 & -23.5 & 1.5 & 0.1 & 28 \\
Clipper-1 & $2815-20$ & 2818 & -24.1 & 1.3 & $<0.1$ & 31 \\
Clipper-1 & $2845-50$ & 2848 & -24.0 & 1.5 & $<0.1$ & 31 \\
Clipper-1 & $2905-10$ & 2908 & -23.7 & 1.8 & $<0.1$ & 29
\end{tabular}

